\author{
UNIVERSIDADE DE SÃO PAULO \\ FACULDADE DE FILOSOFIA, LETRAS E CIÊNCIAS HUMANAS \\ DEPARTAMENTO DE LETRAS CLÁSSICAS E VERNÁCULAS \\ PROGRAMA DE PÓS-GRADUAÇÃO EM LITERATURA BRASILEIRA
}

\begin{abstract}
As representações da 'Natureza' nas obras de Cronistas e Viajantes do Brasil Colonial e seus fundamentos teóricos
\end{abstract}

Marcio Henrique de Mello Pereira

Dissertação apresentada ao Programa de Pós-Graduação em Literatura Brasileira do Departamento de Letras Clássicas e Vernáculas da Faculdade de Filosofia, Letras e Ciências Humanas da Universidade de São Paulo, para a obtenção do título de Mestre em Letras.

Orientador: Prof. Dr. Eduardo de Almeida Navarro

v. 1

Versão Corrigida

São Paulo

2011 


\section{Agradecimentos}

Gostaria de agradecer a todos os professores e amigos que contribuíram para o desenvolvimento desta dissertação; à Patrícia de Jesus Carvalhinhos pelas sugestões e

críticas realizadas na Qualificação; ao professor Élvio Rodrigues Martins que compôs a banca de Qualificação e da defesa da Dissertação que muito contribuiu para os avanços desta pesquisa; ao professor Rafael Ruiz Gonzalez pela análise crítica e pelas devidas sugestões na defesa da Dissertação; e também, ao professor Isaias Artigno Wolfshorndl pela correção de todo o texto.

Agradeço especialmente ao professor Eduardo de Almeida Navarro, pela amizade e confiança que se somaram a precisa orientação.

Gostaria de agradecer também a minha companheira, dançarina e amiga Julia Corrêa Giannetti pela compreensão e ajuda aferida em todas as fases desta pesquisa.

Dedico este trabalho aos meus pais (in Memorian) que sempre me conduziram no caminho dos estudos, da honestidade e do respeito; aos meus tios presentes e ausentes que, desde a mais tenra idade, me incentivaram e ajudaram nos estudos; aos meus primos que habitam carinhosamente minha alma; e, aos meus irmãos, cunhadas e sobrinhos que me confortam e alegram nesta caminhada. 


\section{Sumário}

Resumo/Abstract pág. 04

Introdução pág. 05

Capítulo I - O Conceito de Natureza na História da Filosofia até o século XVIII pág. 36

Capítulo II - As ideias de Natureza presentes na Literatura, sobretudo nas obras de Tratadistas Antigos e Medievais e seus influxos na Idade Moderna. pág. 59

Capítulo III - As Representações da natureza brasileira pág. 67

1 - A posição geográfica e os aspectos astronômicos pág. 67

2 - Os climas pág. 77

3 - A terra e as águas pág. 86

4 - A vegetação pág. 93

5 - Os animais pág. 100

6 - O homem pág. 109

Conclusão pág. 116

Bibliografia pág. 124 


\title{
“As representações da 'Natureza' nas obras de Cronistas e Viajantes do Brasil Colonial e seus fundamentos teóricos"
}

Resumo: Esta pesquisa se propõe a realizar uma análise das representações da natureza encontradas nas obras de alguns cronistas e viajantes do Brasil colonial e averiguar seus fundamentos teóricos.

Palavras-chave: natureza, ontologia, cronistas, viajantes, período colonial brasileiro.

\begin{abstract}
The purpose of this research is to analyse the representations of nature found in the works of some cronists and voyagers during Brazil colonial period and to verify their theoretical bases.
\end{abstract}

Key-words: nature, onthology, cronists, voyagers, Brazil colonial times. 


\section{Introdução}

Nossa pesquisa busca entender as representações da 'Natureza' nas obras de Cronistas e Viajantes do Brasil Colonial. Chamamos de representações as relações com as coisas que nos rodeiam, a partir das ideias que formamos delas. É o modo como, a partir desses entendimentos, as trazemos para nosso campo de significações. ${ }^{1}$

Pensar em Literatura de Viagens é admitir que haja um conjunto de textos que à viagem foram buscar temas, motivos e formas que se identificam como um conjunto autônomo, de acentuado caráter histórico e marítimo, como crônicas, descrições de terras e guias náuticos. Maximamente nos textos que se referem à descoberta e expansão, pois elas só foram historicamente realizadas através das grandes navegações oceânicas e extensas deslocações terrestres, sobretudo à volta de exóticos cenários de terras estranhas que vieram a ser conhecidas como 'Novo Mundo'.2

É diante destes pressupostos, que analisaremos as obras de alguns Cronistas e Viajantes, em língua portuguesa, que compuseram a Literatura do Brasil Colonial nos séculos XVI, XVII e XVIII, assim selecionados: Pero Vaz de Caminha ("Carta de Pero Vaz de Caminha", de 1500); Pero de Magalhães Gandavo ("Tratado da Terra do Brasil”, escrito provavelmente em 1572 e "História da Província de Santa Cruz", impressa em 1576); Fernão Cardim ("Tratados da Terra e Gente do Brasil" que provavelmente teria sido escrita em 1584-5); Gabriel Soares de Sousa ("Tratado Descritivo do Brasil" escrito em 1587); Ambrósio Fernandes Brandão ("Diálogos das Grandezas do Brasil”, de 1618); Bento Teixeira ("Prosopopéia", que suscita dúvidas quanto à data exata do poema, mas que é impresso em 1601); Simão de Vasconcelos (“Crônica da Companhia de Jesus”, escrita em 1663); Basílio da Gama (“O Uraguai”, publicado em 1769); e, Santa Rita Durão (“Caramuru”, poema épico do descobrimento da Bahia, publicado em 1781).

$\mathrm{Na}$ época em que se estabeleceu o contato entre os ibéricos e o chamado "Novo Mundo" surgiu variadas interpretações de sua recém-descoberta "Natureza". Muitas das impressões referentes à Natureza destas novas terras foram registradas por cronistas e viajantes principalmente no período compreendido entre os séculos XVI, XVII e XVIII, em

\footnotetext{
${ }^{1}$ MOREIRA, "Pensar e ser em geografia: ensaios de história, epistemologia e ontologia do espaço geográfico", 2008, p. 106-107.

2 CRISTÓVÃO, "Condicionantes Culturais da Literatura de Viagens", 1999, p. 15-17.
} 
que puderam observá-la, interpretá-la e descrevê-la, relatando à Coroa Portuguesa o conhecimento necessário para implementar o projeto colonial. Conforme avalia Sérgio Buarque de Holanda, em sua obra "Raízes do Brasil",

A tentativa de implantação européia em extenso território, dotado de condições naturais, se não adversas, largamente estranhas à sua tradição milenar, é, nas origens da sociedade brasileira, o fato dominante e mais rico em consequências. Trazendo de países distantes nossas formas de convívio, nossas instituições, nossas idéias, e timbrando em manter tudo isso em ambiente muitas vezes desfavorável e hostil, somos ainda hoje uns desterrados em nossa própria terra. Podemos construir obras excelentes, enriquecer nossa humanidade de aspectos novos e imprevistos, elevar à perfeição o tipo de civilização que representamos: o certo é que todo o fruto de nosso trabalho ou de nossa preguiça parece participar de um sistema de evolução próprio de outro clima e de outra paisagem $(1977$, p. 3$)$.

Sérgio Buarque complementa essa ideia na sua obra "História Geral da Civilização Brasileira" ao afirmar que os portugueses ao colonizar o Brasil, tiveram alguns problemas a serem enfrentados, nas relações que mantiveram com o solo e com os elementos da natureza, e que dependeram muito da tropicalidade marcante desse imenso território.

O período colonial, para José Aderaldo Castello, é o período em que os influxos externos foram preponderantes sobre a "relação homem/terra", constrangendo os influxos internos; entretanto, no decorrer desse período, com a fixação do colonizador e com a miscigenação, principia o desencadeamento do processo lento de conquista da identidade. ${ }^{3}$ Os primeiros escritos documentam a instauração do processo colonial, são informações que viajantes e missionários europeus colheram sobre a natureza e o homem do Brasil, conforme denota Alfredo Bosi. ${ }^{4}$

Desse modo, ao conviverem com o Novo Mundo, os cronistas e viajantes o descreveram e o interpretaram segundo os cânones principais vigentes na Europa no que se referem às influências da religiosidade da época, fruto de concepções filosóficas antigas que percorreram vários séculos, ao contexto histórico-cultural do período dos Descobrimentos e também ao caráter político-econômico proporcionado pela Conquista e suas derivações. Tais interpretações estiveram relacionadas com as posições sociais e as circunstâncias pessoais dos cronistas e viajantes, juntamente com os interesses

\footnotetext{
${ }^{3}$ CASTELLO, “A literatura brasileira - origens e unidade”, vol. 1, 2004, p. 21.

${ }^{4}$ BOSI, "História concisa da Literatura Brasileira", 1997, p. 15.
} 
metropolitanos que envolveram esse período, fazendo com que suas interpretações e descrições fossem usadas para fins de exploração e apropriação da natureza para que favorecessem o seu ambicioso empreendimento colonizador.

Ao raiar o século XVI, segundo análise de Capistrano de Abreu, na obra "Capítulos de História Colonial”, Portugal

[...] labutava na transição da Idade Média para a era moderna. Coexistiam em seu seio duas sociedades completas, com sua hierarquia, sua legislação e seus tribunais; mas a sociedade civil não professava mais a superioridade transcendente nem se sujeitava à dependência absoluta da Igreja, despida agora de muitas de suas históricas prerrogativas, obrigada a reduzir muitas de suas pretensões. O Estado reconhecia e acatava as leis da Igreja, executava as sentenças de seus tribunais, declarava-se incompetente em quaisquer litígios debatidos entre clérigos, só punia um eclesiástico se, depois de degradado, era-lhe entregue por seus superiores ordinários, respeitava o direito de asilo nos templos e mosteiros para os criminosos cujas penas eram de sangue, abstinha-se de cobrar impostos do clero. A Igreja dominava soberana pelo batismo, tão necessário à vida civil como à salvação da alma (1988, p. 55).

Apesar disso, ocorriam frequentes atritos entre a Igreja, que não queria perder seus privilégios provenientes do período medieval - e o Estado - que se fortalecia e assumia novos desafios, sendo que o Papa continuava como mentor da sociedade religiosa e o rei tornara-se o sujeito jurídico da sociedade civil.

No entanto, Portugal considerava a nova terra propriedade exclusiva da Coroa, efetivada pelas concessões papais consolidadas através do Tratado de Tordesilhas, de 1494. Não obstante, João Adolfo Hansen analisa em sua obra “A Sátira e o Engenho" que o dogma católico consubstanciado pela Contrarreforma assevera que o poder é uma instituição natural, fruto de um pacto visível em uma Igreja derivada de Deus, que é a causa primeira da natureza. Nos países católicos, como Portugal e Espanha, o poder era equilibrado entre Estado e Igreja,

[...] em que a Escolástica reciclada pelos dominicanos e jesuítas contrareformistas do século XVI e início do XVII é difundida como ortodoxia pelas instituições universitárias, como Coimbra, Évora e Salamanca, sendo o modelo não só do ensino do Direito, mas também das doutrinas providencialistas do Estado monárquico então produzidas para fazer frente às teses "ímpias" de Maquiavel, Erasmo, Lutero, Calvino e Melanchton. Simultaneamente, mantidas as proporções desta generalização, a arte dita "barroca" do século XVII ibérico corresponde a uma reinterpretação de tópicas da retórica antiga, principalmente 
Aristóteles, Cícero, Quintiliano, Sêneca e Hermógenes, que são mantidas pela doutrina escolástica da analogia de atribuição e proporção com que nessa época se interpreta o conceito engenhoso. Essa reinterpretação, operada em vários graus e intensidades, mantém a normatividade antiga dos gêneros, da divisão dos estilos e da verossimilhança, adaptando-a aos novos fins da centralização monárquica. É ela que permite pensar o espetáculo maravilhoso da arte como proliferação retoricamente ordenada em função da unidade de sua Causa Primeira implícita que, por isso, sempre efetua os vestígios do sagrado, mesmo quando cortesã e programaticamente ornamental. [...]. Assim, certos procedimentos artísticos foram apropriados pela máquina católica da propaganda da fé: por exemplo, o binarismo das antíteses, a construção geométrica do poema como oposição de "sensível"/"inteligível", que poetas portugueses e espanhóis desenvolvem como diluição de Camões e Góngora, são muito conformes com a piedade católica e seu dogma da natureza humana decaída (2004, p. 265-266).

Conforme parecer de Sérgio Buarque de Holanda, na obra "Raízes do Brasil", na Idade Média, o mundo era organizado segundo leis eternas, impostas pelo criador e supremo ordenador de todas as coisas:

A hierarquia do pensamento, perante a Idade Média, subordinava-se a uma hierarquia cosmogônica. A coletividade dos homens na terra era uma simples parábola e espelhava palidamente a cidade de Deus. Assim, na filosofia tomista, os anjos que compõem as três ordens da primeira hierarquia, os Querubins, os Serafins e os Tronos, são equiparados aos homens que formam o entourage imediato de um monarca medieval: assistem o soberano no que ele realiza por si mesmo, são os seus ministros e conselheiros. Os da segunda hierarquia, as Dominações, as Potências e as Virtudes são, em relação a Deus, aquilo que para um rei são os governadores por ele incumbidos da administração das diferentes províncias do reino. Finalmente, os da terceira hierarquia correspondem, na cidade temporal, aos agentes do poder, os funcionários subalternos (1977, p. 5-6).

Nesse quadro político-religioso foi que predominaram, no século XVI, principalmente no espaço litorâneo brasileiro, as interpretações dos cronistas e viajantes, correspondentes à prosa informativo-descritiva, e quanto à poesia, prevaleceram os monólogos e os diálogos que visavam à catequese. Conforme José Aderaldo Castello, ao observarmos a literatura do Brasil Colônia, "só podemos divisionar a diferenciação de estilos e formas literárias, a contar do Classicismo quinhentista ao Barroco e Arcadismo, no domínio da poesia lírica e épica, na qual prevalecerá o modelo camoniano” $(2004$, p. 136). Nesse século inicia-se a transferência de valores europeus para o Novo Mundo, e se estabelece a integração do colonizador, pleno de sentimentos de deslumbramento com a natureza e com sua promissora possibilidade de riquezas. 
Antonio Cândido, na obra "Formação da literatura brasileira - momentos decisivos" concorda com esta visão de Castello, ao afirmar que "a literatura colonial era um aspecto da literatura portuguesa" (2006, p. 72), em que a natureza americana propiciara uma conotação exótica, mas, nunca para lhe dar autonomia, pois a natureza há de corresponder à visão de mundo, ao sentimento especial que transforma a natureza física numa vivência. ${ }^{5}$ Visão de mundo que correspondia ao humanismo renascentista predominante na Europa.

Em princípios do século XVI, já podemos observar traços desse humanismo no Novo Mundo, na primeira "Carta" do território brasileiro, tida como a certidão de nascimento do Brasil, escrita pelo viajante portulano Pero Vaz de Caminha nos dez dias posteriores a 22 de abril de 1500, de modo que, ao descrever a natureza, nos relata que avistaram um grande monte, que ficou conhecido como Monte Pascoal, circundado por grandes arvoredos. Escrita no alvorecer da Renascença portuguesa, a Carta de Pero Vaz de Caminha foi influenciada por narrativas de viagens e reflete a visão que o europeu tinha do mundo naquele momento em que os saberes dos antigos eram postos em dúvida pelos conhecimentos adquiridos nas novas descobertas geográficas que, a partir do século $\mathrm{XV}$, os navegantes portugueses realizaram.

A Carta de Caminha, segundo informe de Alfredo Bosi, insere-se em um gênero representado durante o século XV em Portugal e Espanha, denominado "Literatura de Viagens", consubstanciado, em Caminha, por um espírito observador e uma transparente ideologia mercantilista batizada pelo zelo missionário de uma cristandade ainda medieval. ${ }^{6}$

A descoberta do Brasil acabou por atrair negociantes interessados no pau-brasil, preciosa madeira cor de brasa, conhecida pelos tupinambás como "ibirapitanga". Isso foi suficiente para que a terra descoberta mudasse de nome, ainda na primeira década do século XVI, passando de "Terra do Brasil" para "Brasil", que, em celta, quer dizer Ilhas Afortunadas ${ }^{7}$. O nome Brasil, segundo constatação de Capistrano de Abreu, em sua obra “Capítulos de História Colonial”, “já era bem conhecido e figurava em portulanos anteriores às descobertas dos portugueses" (1988, p. 69). Frei Vicente de Salvador relata em sua obra "História do Brasil", que

\footnotetext{
${ }^{5}$ CÂNDIDO, "Formação da literatura brasileira - momentos decisivos", 2006, p. 72.

${ }^{6}$ BOSI, "História concisa da Literatura Brasileira", 1997, p. 17.

${ }^{7}$ FONTANA, “O Brasil de Américo Vespúcio”, 1995, p. 135.
} 
Como o demônio com o sinal da cruz perdeu todo o domínio que tinha sobre os homens, receando perder também o muito que tinha em os desta terra, trabalhou que se esquecesse o primeiro nome e lhe ficasse o de Brasil, por causa de um pau assim chamado de cor abrasada e vermelha com que tingem panos, do qual há muito, nesta terra, como que importava mais o nome de um pau com que tingem panos que o daquele divino pau, que deu tinta e virtude a todos os sacramentos da Igreja, e sobre que ela foi edificada e ficou tão firme e bem fundada como sabemos (1982, p. 57).

Em 1343, o capitão Sancho Brandão abordara uma ilha no oceano atlântico, terra magnífica, habitada por homens nus, opulenta em árvores de tinta vermelha, em que a denomina Ilha do Brasil ou de Brandão, de onde os portugueses monopolizaram o comércio de pau-brasil. Fato que pode ser confirmado pelos escritos de Duarte Pacheco Pereira, que a mando de Dom Manoel em 1498, lhe relata que fora encontrada imensa terra firme, em que se achou muito e fino Brasil. ${ }^{8}$ No roteiro de Gonneville de 1503 esta terra já tem o nome de Brasil e em 1511 aparece já este nome em documento oficial. ${ }^{9}$

Em Portugal, detalhes sobre o descobrimento do Brasil foram impressos, pela primeira vez, na segunda metade do século XVI. “A Terra Santa Cruz pouco sabida”, foi como a chamou Luís Vaz de Camões nos tercetos que antecedem à História da Província Santa Cruz, de Pero de Magalhães Gandavo ${ }^{10}$, o primeiro livro português dedicado exclusivamente ao Brasil, impresso em 1576. No entanto, Pero Vaz de Caminha, através de sua experiência, deixou precioso legado histórico e literário em sua Carta, que é o ponto de partida da exaltação da terra aos olhos do colonizador, dirigida a Dom Manuel, à maneira de diário, "referente ao impacto ante o encontro da quarta parte do mundo, constituída por um universo novo, diferente, exótico, tendente ao maravilhoso, que se transformou em solo fértil [...] para o apostolado da evangelização cristã” (PEREIRA, 1999, p. 28).

Por mais de três séculos, o principal documento da descoberta do Brasil permaneceu desconhecido no Arquivo da Torre do Tombo, em Lisboa, sendo redescoberto somente em 1773, pelo guarda-mor do arquivo, José Seabra da Silva. Ainda assim, quase meio século se passaria antes que a carta de Pero Vaz de Caminha fosse publicada pela primeira vez, pelo padre Manuel Aires do Casal, em sua “Corografia Brasílica”, editada em 1817.

\footnotetext{
${ }^{8}$ CINTRA, "Nossa Primeira História", 1922, p. 6-10.

9 ABREU, “O descobrimento do Brasil”, 1999, p. 34-35.

${ }^{10}$ GANDAVO, "Tratado da Terra do Brasil - História da Província de Santa Cruz”, 1980, p. 70.
} 
No entanto, a Carta do Mestre João e a chamada "Relação do Piloto Anônimo", publicada em 1507, ficaram de início, muito mais famosas que o relato de Caminha. Essa "Carta" retrata o testemunho direto do encontro dos navegadores portugueses com os naturais da terra. Segundo Paulo Roberto Pereira nos informa em sua obra "Os três únicos testemunhos do descobrimento do Brasil", o significado singular desse encontro do europeu com o nativo foi à reformulação de valores no confronto com o outro, em que se aventou a possibilidade de se confirmar a existência de uma região onde a vida era paradisíaca, sem as exigências do mundo civilizado. Realça em sua descrição a beleza do índio na sua inocência tropical, Caminha realça a beleza do natural da terra, de modo a desfazer o mito medieval de que nos trópicos os seres humanos fossem disformes. ${ }^{11}$

A Carta de Caminha foi um de seus últimos atos, já que, quando a feitoria lusitana em Calicute foi atacada, em dezembro de 1500, entre os mortos estava o cronista do nascimento do Brasil. Apesar de Caminha registrar impressões superficiais da natureza e de descrever o indígena ingenuamente, ele sugere a busca de riquezas fáceis, atreladas à visão do Eldorado.

Segundo a interpretação de José Aderaldo Castello, por causa das ambições despertadas, as incursões de outros europeus levaram o colonizador português a defender determinados pontos do vasto litoral brasileiro e a combater os invasores, uma vez que a chegada dos portugueses quase coincidiu com a dos franceses. Ainda nos últimos tempos de Dom Manuel, começaram os protestos contra a presença francesa no litoral, mas, após a ascensão de Dom João III, a situação agravou-se, tornando-se necessário o envio de uma armada comandada por Cristóvão Jacques, em 1527, para defender a costa brasileira.

Com tal propósito, também chega ao Brasil Martim Afonso de Sousa que, além de defendê-la, tem a missão de efetuar o povoamento da terra e, assim, funda a vila de São Vicente, em 1532, e nesse mesmo ano parte de Dom João III a resolução de demarcar a costa brasileira em capitanias hereditárias e doá-las a fidalgos, fato que se concretizará somente em 1534, ao fixar o limite sul na costa de Santa Catarina, e o limite norte até o Maranhão. Os donatários poderiam fundar vilas ao longo da costa e dos rios navegáveis, seriam senhores de ilhas ao entorno, até a distância de dez léguas da costa e também

\footnotetext{
${ }^{11}$ PEREIRA, “Os três únicos testemunhos do Descobrimento do Brasil”, 1999, p. 64-66.
} 
poderiam distribuir terras através do sistema de sesmarias, sendo que em várias capitanias foram nomeados vigários e capelães, sempre em prol da expansão da fé cristã.

A Companhia de Jesus, por meio de igrejas suntuosas, de imagens de Santos e de cúpulas pintadas, cujas perspectivas encaminhavam o olhar para o céu, propôs-se de arrebatar, em todo o orbe, o homem aos seus interesses cotidianos, e fazer com que ele voltasse os seus pensamentos para as coisas divinas. ${ }^{12}$ D. João III era monarca católico, defensor dos termos do decreto, considerando quanto serviço de Deus "ser a minha terra e costa do Brasil mais povoado do que até agora foi, assim para nela haver de celebrar o culto de ofícios divinos, e se exaltar a nossa santa fé católica, com trazer e provocar a ela os naturais da dita terra infiéis e idólatras" (HOLANDA, 1960, p. 99).

Para Sérgio Buarque de Holanda, os portugueses, que foram os pioneiros da conquista dos trópicos para a civilização, tiveram as melhores condições, se comparados a outros povos do velho mundo, "para se aventurar à exploração regular e intensa das terras próximas à linha equinocial, onde os homens depressa degeneram, segundo o conceito generalizado na era quinhentista" (1977, p. 12). Desse modo, os portugueses consolidavam a dominação e ampliavam as fronteiras, fato propiciado pelo apresamento e escravização do índio em busca de riquezas. Porém, na perseguição ao índio, feriam-se os ideais humanísticos, associados à propagação da cristandade, que foi uma das intenções do expansionismo português. ${ }^{13}$

Diante das efervescentes ocorrências no âmbito político-religioso europeu, foi de vital importância a criação da Ordem da Companhia de Jesus, fundada por Inácio de Loyola em 1534, e oficializada pelo Papa Paulo III, em 1540, que proporcionou uma nova organização hierárquica na Igreja Católica que, através dos "soldados de Cristo", vieram instaurar a catequização e a defesa do índio no Brasil, impondo seu espírito ao mundo católico, desde as resoluções perpetradas pelo Concílio de Trento.

De acordo com os fundamentos da Companhia de Jesus, o destino supremo do homem tem de agir em conformidade com a vontade de Deus e enquadrar-se na mais elevada ordem moral, sendo que todas as criaturas da terra foram criadas exclusivamente

\footnotetext{
${ }^{12}$ MILLER, “Os Jesuítas - seus segredos e seu poder”, 1932, p. 464-465.

${ }^{13}$ CASTELLO, "A literatura brasileira - origens e unidade", vol. 1, 2004, p. 38.
} 
por causa do homem, a fim de que ele as use na medida em que lhe sejam de utilidade na consecução do fim que lhe foi assinalado por Deus. ${ }^{14}$

Somente a partir da criação do primeiro governo geral e da chegada dos jesuítas ao Brasil, em 1549, é que se intensificam a colonização e a formação de vários núcleos urbanos. Para José Aderaldo Castello, os colégios da Companhia de Jesus, juntamente com os conventos de outras ordens religiosas como a beneditina, a franciscana e a carmelita, marcaram sucessivamente, de modo fundamental, o desenvolvimento geral da colonização e o crescimento dos principais centros urbanos do Brasil-Colônia, situados em São Vicente e São Paulo, em Salvador, em Recife e Olinda na capitania de Pernambuco, no Rio de Janeiro e, posteriormente, em Ouro Preto.

No século XVI, os jesuítas se expandiram para o nordeste, até o Rio Grande do Norte e Ceará, para o sul, até Santa Catarina e Rio Grande do Sul, mas os principais centros desta ordem religiosa foram em Salvador, Pernambuco, Rio de Janeiro e São Paulo, dentre outros de menor importância nesse período. Esta informação descritiva indica-nos o cumprimento de uma missão humanística de cristianização que passa à responsabilidade principal da Companhia de Jesus, enquanto permaneciam com o colonizador os objetivos da exploração da terra, sempre motivadas pelos sonhos do Eldorado ou pela "visão do paraíso", conforme tese defendida por Sérgio Buarque de Holanda.

No contexto de exploração e povoamento do Brasil foi que o português Pero de Magalhães Gandavo, após residir em terras brasileiras, redige na Metrópole as crônicas históricas "Tratado da Terra do Brasil", provavelmente escrita em 1572 e dedicada ao Príncipe Dom Henrique, no ano da divisão do Brasil em dois governos, um com sede em Salvador e o outro em São Sebastião; e a "História da Província Santa Cruz", impressa em 1576 e dedicada a Dom Lionis Pereira, em que o cronista descreve a região que se estende desde São Vicente até o sul da Bahia, em que "mais de uma vez repete que seu projeto se reduz a mostrar as riquezas da terra, os recursos naturais e sociais nela existentes, para excitar as pessoas pobres a virem povoá-la", e que, "seus livros são uma propaganda de imigração", conforme registro de Capistrano de Abreu. ${ }^{15}$ Mesmo com a divisão do Brasil em dois governos, a Bahia sobre a qual escreve Gandavo era a principal sede do Brasil-

\footnotetext{
${ }^{14}$ MILLER, “Os Jesuítas - seus segredos e seu poder”, 1932, p. 23.

${ }^{15}$ ABREU, in: GANDAVO, “Tratado da Terra do Brasil - História da Província de Santa Cruz”, 1980 , p. 15.
} 
Colônia e o mais importante centro político-econômico, cuja hegemonia se manterá até o século XVII.

Segundo Alfredo Bosi, Gandavo era humanista, católico e estava interessado no desenvolvimento do Reino. A sua atitude íntima, na esteira de Camões, e que se rastreara até os épicos mineiros, consiste em louvar a terra. ${ }^{16}$

O que levou Gandavo a escrever a "História da Província Santa Cruz" foi o relativo descompromisso por parte da Coroa portuguesa em não efetivar um sistema de proteção de nosso litoral, uma vez que os estrangeiros o conheciam melhor do que os próprios portugueses e, por isso, era fundamental levar as notícias do Brasil ao rei de Portugal Dom Sebastião. ${ }^{17}$ De forma semelhante será motivo para a execução da obra "Tratado da Terra do Brasil", evidenciar a fertilidade e abundância da terra do Brasil, e reforçar a ideia de que "esta terra é tam natural e favorável aos estranhos que a todos agazalha e convida como remedio por pobres e desamparados que sejão" (GANDAVO, 1980, p. 22). Segundo José Aderaldo Castello, "com Gandavo tivemos a primeira tentativa sistematizadora de descrição da terra, acentuando o enfoque comparativo com as coisas distantes de além mar e, também, o primeiro esboço da história do Brasil Colônia” (vol. 1, 2004, p. 59).

Nesse período em que vivia Gandavo, ainda se tinha como referência a obra "História Natural" de Plínio, o Velho, mas, diferentemente dos Tratadistas da História Natural, em que muito do que era interpretado se mantinha de forma idealizada, nesta época do Renascimento verificava-se uma maior experimentação e observação direta da terra, começavam a surgir as obras que se referiam às novas espécies da fauna e da flora encontradas neste Novo Mundo, diferentes e estranhas, não só para o antigo mundo renascentista, mas, também, ausentes dos saberes antigos, registrados nos clássicos gregos e romanos. E, conforme Sheila Moura Hue na introdução a obra "A Primeira História do Brasil", Gandavo foi o primeiro a descrever plantas e animais do território brasileiro, e que, diante do novo, não se volta às referências clássicas, mas se abre para novas interpretações e descrições da natureza, baseadas em suas próprias experiências.

Gandavo noticia as principais características da terra e se mostra deslumbrado com a flora tropical. Alfredo Bosi interpreta que é possível entrever certo otimismo quanto às

\footnotetext{
${ }^{16}$ BOSI, "História concisa da Literatura Brasileira", 1997, p. 18.

${ }^{17}$ GANDAVO, "Tratado da Terra do Brasil - História da Província de Santa Cruz”, 1980, p. 76.
} 
potencialidades da colônia, ainda imerso "em uma credulidade pré-renascentista, pode falar sem rebuços em "visão do paraíso" como leitmotiv das descrições: Eldorado, Éden recuperado, fonte da juventude, mundo sem mal, volta a Idade de Ouro" (1996, p. 19).

Deste modo, ao experienciar a natureza brasileira, de acordo com Sheila Moura Hue em prefácio à obra "A primeira história do Brasill", Gandavo atesta que

[...] a natureza brasileira - no que tem de exótico, maravilhoso, e no que promete de riquezas, com suas imensas plantações de cana-de-açúcar e algodão, no seu pau-brasil e na abundância de 'mantimentos' e caça - ainda reflete o tradicional tema do horto das delícias, mas um horto apresentado, quase sempre, sob o ponto de vista da produção: Gândavo descreve plantas e animais com a preocupação de indicar sua utilização (2004, p. 23-24).

É com esse afinco em observar e interpretar o que encontra neste Novo Mundo, sabendo da importância de sua contribuição para o empreendimento da exploração por parte da Coroa portuguesa que Gandavo "nomeia as árvores, destacando as frutas; enumera os peixes mais dignos de nota, trata de diversos animais, encarece as belezas do céu e as excelências do clima e não esquece os índios" (1980, p. 15).

A "História da Província Santa Cruz" se apresenta como um relato de uma região pouco conhecida, em que os estranhos e bárbaros costumes do índio, natural da terra, e as novas e diferentes espécies exóticas da fauna e da flora nunca antes descritas maravilhavam o olhar europeu e atuavam na construção de uma nova visão de mundo, na visão de um cronista que obteve amplo conhecimento da costa brasileira.

Para Sérgio Buarque de Holanda, o que dita as descrições e reflexões desde Pero Vaz de Caminha e Gandavo até, ao menos, Frei Vicente do Salvador, é uma curiosidade e uma inspiração utilitária. E o que ameaça desafiar o costume e a ordem da Natureza, pode ocasionalmente acarretar alguma vaga sugestão de mistério, "podiam admitir o maravilhoso, e admitiam-no até de bom grado, mas só enquanto se achasse além da órbita de seu saber empírico" (HOLANDA, 1996, p. 5).

Logo após os escritos de Gandavo, tivemos uma importante mudança política, que se estendeu desde 1580, quando se extingue a dinastia de Avis em Portugal, até 1640. Ao morrer D. Sebastião, em Alcácer-Quebir, em 1578, passou a reinar em Portugal o Cardeal D. Henrique, florescendo a partir daí a lenda do Sebastianismo. 
Como não houvesse mais descendentes legítimos, extinguiu-se no Cardeal-Rei a dinastia de Avis, consolidando e dando feição própria a nação portuguesa. Iniciou-se, após a morte do Cardeal D. Henrique, o período da dominação espanhola. Prolongou-se esta fase por um período de 60 anos, abrangendo os reinados de Filipe II (I de Portugal), Filipe III e, em parte, o de Filipe IV. Sob o reinado deste último, deu-se a revolução restauradora que elevou, ao trono português, D. João, Duque de Bragança, e futuro D. João IV, terminando assim a dominação espanhola sobre Portugal. ${ }^{18}$

Nesse período houve a União Ibérica, em que Portugal é anexado à Espanha, e no qual, devido a essa transformação, o Brasil teria seus limites naturais estendidos, tanto para o Amazonas e para a Bacia Platina, quanto para o oeste, em que tacitamente caíam por terra os limites do Tratado de Tordesilhas. Desse modo, os cronistas e viajantes que escreveram nesse período dirigiam suas obras ao domínio hispânico, sob o reinado de Filipe II.

Será nesse período da União Ibérica que Gabriel Soares de Sousa, em sua obra “Tratado Descritivo do Brasil”, escrita em 1587, faz síntese descritivo-informativa do século XVI, sendo que nela se encontram importantes dados para a compreensão da formação brasileira, uma descrição minuciosa da costa, desde o rio Amazonas até o rio da Prata, considerados por ele "dois portentos da natureza". Esse cronista português também descreve a distribuição das várias tribos indígenas com o registro dos seus hábitos, ao mesmo tempo em que realiza a descrição da terra, das plantas e dos animais, e prevê um próspero futuro para as terras brasileiras. ${ }^{19}$

Gabriel Soares de Sousa chegou provavelmente ao Brasil na armada que trouxe o governador Francisco Barreto, em 1569. Fixou-se na Bahia, onde prosperou, adquiriu fazendas e construiu engenhos de açúcar, comprou terrenos na cidade de Salvador, e deve ter viajado muito até as capitanias do Sul, já que revela amplo conhecimento delas ao descrever a costa e os acidentes geográficos dessa região, como constam em sua obra "Tratado Descritivo do Brasil", apontado em seu prólogo por Américo Jacobina Lacombe.

Certa vez, seu irmão, João Coelho de Sousa, ao chefiar uma entrada para o interior da Bahia, recolheu amostras de pedras preciosas. Após essa descoberta, veio a falecer, mas, um pouco antes dessa tragédia pessoal, ele remeteu todo esse material a Gabriel Soares de

\footnotetext{
${ }^{18}$ HOLANDA, "História Geral da Civilização Brasileira", Tomo I - A Época Colonial, 1960, p. 176.

${ }^{19}$ LACOMBE, "Prólogo", in: SOUSA, "Tratado Descritivo do Brasil”, 1987, p. 5.
} 
Sousa, que, de posse do roteiro, partiu para a corte espanhola, a fim de obter do rei Filipe II concessões para a execução de um plano de exploração do interior para além do rio São Francisco. Durante o tempo em que o rei analisava esse pedido, Gabriel Soares escrevia o seu Tratado, que concluiu em 1587, no qual justifica sua confiança no futuro da terra e alerta a Metrópole sobre o risco de uma possível invasão estrangeira.

De volta ao Brasil, em 1590, Gabriel Soares organiza sua ambiciosa expedição, segue rumo ao sertão nordestino, construindo fortes, à procura da incógnita lagoa dourada do Vupabuçu e Paraupava, nas bandas do São Francisco. Contudo, no momento em que se encontrava nas cabeceiras do rio Paraguaçu, falece vítima de paludismo. Diante desse fato, o governador Francisco de Sousa ordenou que a expedição voltasse à Bahia. Não obstante, posteriormente, o próprio governador seria um dos "entradeiros" do sertão. ${ }^{20}$ Lembrando que passado mais de um século, serão descobertos, justamente naquele rumo, aluviões auríferos em Mato Grosso, conforme salienta Sérgio Buarque, em "Visão do Paraíso".

De acordo com Eduardo de Almeida Navarro em artigo intitulado "Uma sinopse da Literatura de Viagem no Brasil dos séculos XVI e XVII", a obra "Tratado descritivo do Brasil em 1587" de Gabriel Soares é de fundamental importância para o conhecimento da fauna e da flora do Brasil, pois descreve muitos nomes de plantas e animais em tupi antigo.

Gabriel Soares foi um colonizador que se fixou na terra, mas que ao final de sua vida queixou-se do esquecimento dela pelos soberanos que sucederam Dom João III, porque, segundo ele, a terra do Brasil é muito rica, fato que possibilita a formação de um poderoso império. ${ }^{21}$ Ele fortalece a consciência nativista pela exaltação da terra e revigora a atitude que exprime o deslumbramento diante dela e de sua valorização, já iniciada por Pero Vaz de Caminha e seguida por Pero de Magalhães Gandavo.

O século XVI teve como características principais as primeiras implementações dos núcleos urbanos, sob a necessidade premente de consolidar a conquista do território e de sua administração, e expandir a ordem espiritual. Desse modo, um elemento comum às obras destes cronistas e viajantes portugueses do referido século foi a prosa informativa, que junto à crônica histórica, tão comum neste tipo de relato de novas paisagens e dos índios naturais da terra, forneceram os principais dados para o expansionismo ibérico.

\footnotetext{
${ }^{20}$ LACOMBE, "Prólogo". In: SOUSA, “Tratado Descritivo do Brasil”, 1987, p. 6-7.

${ }^{21}$ Ibidem, p. 9.
} 
Outro autor selecionado para esta pesquisa foi o português Fernão Cardim, que era integrante da Companhia de Jesus desde 1555, período em que foi ministro do colégio de Évora. No entanto, só em 1583 é que chega a Bahia e, ao longo de sua vida, passou por Ilhéus, Porto Seguro, Pernambuco, Espírito Santo, Rio de Janeiro, São Vicente e Bahia e, de acordo com Capistrano de Abreu, a obra "Tratados da Terra e Gente do Brasil" teria sido escrita em fins do século XVI, em 1584 ou em 1585, e visava à informação, observação e descrição das naturezas da terra e do índio.

Sua obra trata das realizações da Companhia de Jesus no Brasil, principalmente da catequização do índio e da colonização. Segundo Rodolfo Garcia, em introdução à obra "Tratados da terra e gente do Brasil", Fernão Cardim fez parte das primeiras missões jesuíticas que chegaram as terras brasileiras, com o projeto de catequização dos indígenas da costa, onde escreveu sobre o Brasil primitivo, presenciou os últimos anos de vida de José de Anchieta, em 1597 e, tempos depois, recebeu o padre Antonio Vieira no Colégio do Terreiro de Jesus, na Bahia. ${ }^{22}$

Fernão Cardim foi reitor do colégio da Bahia e de São Sebastião do Rio de Janeiro. Em 1598, foi eleito provincial da Província do Brasil, em Roma, e certa vez, quando regressava dessa missão, em 1601, se confrontou com naus de corsários ingleses, comandados pelo capitão Cook, que o levou para a Inglaterra, lá permanecendo até ser resgatado. Porém, nessa ocasião foi despojado dos manuscritos que levava consigo e que chegaram às mãos do londrino Samuel Purchas. Cardim retornou ao Brasil em 1604, como provincial, cargo que exerceu até 1609, passando novamente ao de reitor do Colégio da Bahia. De seus escritos, o primeiro a ser divulgado pela imprensa em língua portuguesa foi a "Narrativa epistolar de uma viagem e missão jesuítica" pela Bahia, Ilhéus, Porto Seguro, Espírito Santo, Rio de Janeiro e São Vicente, desde 1583 até 1590. Estava ainda nas mãos de Cardim o cargo de vice-provincial quando os holandeses tomaram a Bahia, em 1624. Na ausência do provincial, Cardim assumiu o governo da Província, em momento muito difícil, sendo que logo após ficou doente e veio a falecer em $1625 .{ }^{23}$

Cardim trouxe muita luz para o conhecimento da primeira colonização do Brasil e, segundo Rodolfo Garcia,

\footnotetext{
${ }^{22}$ GARCIA, "Introdução", in: CARDIM, “Tratados da Terra e Gente do Brasil”, 1980, p. 12.

${ }^{23}$ Ibidem, p. 14-17.
} 
[...] há o geógrafo que estuda a terra e suas divisões, estuda o clima e suas condições de habitabilidade; há também o etnógrafo que descreve os indígenas, seus usos e costumes; há o zoólogo e o botânico que trata da fauna e da flora farta e desconhecida, e há também o historiador que discorre sobre as missões dos jesuítas, seus habitantes e as causas do progresso ou da decadência da Colônia (Apud CARDIM, 1980, p. 13).

Antônio Vieira afirma ser Fernão Cardim um homem religioso e de vida inculpável. Em seus escritos é constatada uma escrita simples, sem artifícios de estilo e sem preocupações eruditas, apesar de possuir ampla cultura, tanto religiosa, que o qualificou como um bom orador, quanto profana, com imenso saber secular, especialmente em medicina, "suas descrições de plantas e animais são muito bem realizadas, como as de um bom naturalista” (GARCIA, apud CARDIM, 1980, p. 20).

Ao chegar ao Brasil, Cardim foi recebido com muita hospitalidade pelos indígenas e pelos colonos e, nos relata que o clima do Brasil é temperado e saudável, sem grandes calmas nem frios, fato este que propiciava aos homens terem uma vida longa, com poucas enfermidades, se comparado à Europa. Também nos ressalta Garcia, que, para ele, era como se a baía do Rio de Janeiro fora pintada pelo supremo pintor e arquiteto do mundo. ${ }^{24}$

Conforme José Aderaldo Castello, o período que se estende de 1601 a 1768 é literariamente dominado pelo estilo barroco $^{25}$, que tem como ponto de referência a publicação do poema "Prosopopeia" de Bento Teixeira, impresso em 1601. Não obstante, Bento Teixeira está mais preso aos "reflexos tardios do quinhentismo português entre nós do que à época barrôca, apesar de alguns artifícios que apresenta, exemplificados sobretudo pelo sonêto que o acompanha" (1969, p. 63).

Segundo Alfredo Bosi nos informa na obra "História concisa da Literatura Brasileira", o estilo barroco se enraizou com mais vigor nas esferas da Europa neolatina que sofreram o impacto vitorioso dos novos estados mercantis:

É na estufa da nobreza e do clero espanhol, português e romano que se incuba a maneira barroco-jesuítica: trata-se de um mundo já em defensiva, organicamente preso a Contra-Reforma e ao Império filipino, e em luta com as áreas liberais do Protestantismo e do racionalismo crescente na Inglaterra, na

\footnotetext{
${ }^{24}$ GARCIA, "Introdução", in: CARDIM, “Tratados da Terra e Gente do Brasil”, 1980, p. 21.

${ }^{25}$ CASTELLO, "Manifestações literárias da Era Colonial”, 1969, p. 61.
} 
Holanda e na França. É instrutivo observar que o barroco-jesuítico não tem nítidas fronteiras espaciais, mas ideológicas (1996, p. 33).

Ainda conforme Alfredo Bosi, o que envolve o barroco está saturado pela experiência do Renascimento e herda as suas formas de elocução maduras e crepusculares: o classicismo e o maneirismo, no qual "o artista barroco mantém um distanciamento da práxis, entende-se que a natureza e o homem se constelassem na sua fantasia como quadros fenomênicos instáveis" (1996, p. 34-35). Assim, o poemeto de Bento Teixeira pode ser considerado um primeiro exemplo de maneirismo nas letras da colônia.

Bento Teixeira nasceu em 1560 ou 1561, em Portugal. Ainda criança veio ao Brasil, morar na capitania do Espírito Santo, onde estudou com os padres da Companhia de Jesus. Seguiu para o Rio de Janeiro, onde estudou "latinidade" referente a súmula de Teologia Moral, com os jesuítas. Do Rio, mudou-se para a Bahia, onde forçosamente acabou por não concluir seus estudos de latinidade e artes, vítima da injustiça de um colega; assim precisou mudar-se para Ilhéus, aonde se casou com Felipa Raposa. De Ilhéus seguiu para Olinda lecionar latinidade. ${ }^{26}$

Como o ouvidor Martim Leitão havia-lhe retirado o auxílio, teve de morar em Igaraçu, onde continuou lecionando. Começam nesse tempo muitas brigas conjugais devido à infidelidade da esposa, o que o levou a regressar a Olinda, e desta cidade foi residir no Cabo, na qual acabou por assassinar a esposa, por volta de 1593 ou 1594, retornando à Olinda, onde passa a viver no Mosteiro de São Bento. Tinha, em 1595, trinta e quatro anos, quando Heitor Furtado de Mendoça lhe deu ordem de prisão e foi levado para Lisboa, onde foi processado pelo Santo Ofício por práticas judaicas, que acabou por confessar em 1597. $\mathrm{O}$ poeta foi considerado herege e apóstata perante a Igreja Católica e sentenciado à excomunhão. As confissões a esse respeito encerraram-se em 1598; um ano após, consegue a liberdade, mas vem a falecer em $1600 .{ }^{27}$

Nessa época em que vive Bento Teixeira, Pernambuco está sob o comando do governador Jorge de Albuquerque Coelho, herdeiro de Duarte da Costa. Essa capitania é a principal produtora de açúcar do Brasil, tendo Recife e Olinda como seus maiores produtores. "Prosopopeia" faz louvação da terra enquanto colônia, "sem ainda se atribuir

\footnotetext{
${ }^{26}$ MOTA, "Introdução”, in: TEYXEYRA y PILOTO, “Naufrágio e Prosopopea”, 1969, p. XXX-XXXI.

${ }^{27}$ Ibidem, p. XXXI-XXXIII.
} 
um expresso sentimento nativista", segundo interpreta Alfredo Bosi. Além da importância econômica que adquire, Pernambuco será, nos séculos XVII e XVIII, o centro de importantes acontecimentos históricos, como a invasão holandesa.

O poema épico "Prosopopeia", de Bento Teixeira, teve como modelo "Os Lusíadas”, de Camões. Apesar de revelar conhecimento de Horácio e Ovídio, domina-o o "espírito escolástico", sendo que também teve conhecimentos da mitologia virgiliana, e tenta transplantar o universo mitológico para a natureza americana, ao opor os deuses mitológicos ao Deus do cristianismo, mas termina a obra adotando o estilo mitológico, e segundo Fernando Mota, “o assunto do poema é histórico e pernambucano; a forma, inclusive alguns versos, servilmente camoniana; o fundo mitológico, porém mais virgiliano do que camoniano" (apud TEYXEYRA y PILOTO, 1969, p. XL).

Este poema está vinculado a figuras e acontecimentos do primeiro século da colonização do Brasil, em que Bento Teixeira desenvolveu-o em forma de oitava rima, sendo composto de 94 estrofes. Já, o vocábulo prosopopeia, de acordo com o Pequeno Vocabulário Ortográfico da Língua Portuguesa, origina-se do grego e pode ser tomado como figura de retórica, designando a figura de pensamento pela qual se atribui vida a seres inanimados ou atos humanos a seres irracionais, ou, ainda, um discurso suposto, atribuído à personagem real ou fictícia, e será nesta acepção que dele se serve Bento Teixeira. ${ }^{28}$

Entretanto, existe historicamente um debate em torno do reconhecimento da autoria da obra "Prosopopeia", em ser atribuída a esse Bento Teixeira apresentado ou a outra pessoa. No entanto, parece que nos dias de hoje essa autoria do poema parece estar de posse desse mesmo Bento Teixeira; porém, não constitui objetivo desta pesquisa adentrar em pormenores sobre essa questão.

Sua obra e sua formação intelectual o vinculam ao Brasil e, particularmente, realiza importantes considerações sobre a prosperidade da capitania de Pernambuco e as lutas entre índios e invasores. Foi o primeiro a celebrar em verso o alvorecer da nossa História, manifestando um forte sentimento nativista. João Adolfo Hansen, em sua obra "A Sátira e o Engenho", assegura que nesse período denominado Barroco, em que Bento Teixeira escreve, pode-se observar que:

\footnotetext{
${ }^{28}$ MOTA, "Notas”, in TEYXEYRA y PILOTO, “Naufrágio e Prosopopea”, 1969, p. 155.
} 
Um mesmo princípio metafísico e político, a oposição complementar de finito/infinito, ordena as práticas de representação luso-brasileiras no século XVII como uma mathesis orientada hierarquicamente. Ela recicla Aristóteles e Santo Tomás de Aquino, principalmente, como doutrina da sindérese, a centelha acesa na consciência pela luz natural da Graça inata, que evidencia a presença do infinito aconselhando o livre-arbítrio do juízo finito na vituperação que repõe os bons usos do costume corrompidos pelos abusos (2004, p. 26).

A produção informativo-descritiva e literária do século XVI marca as origens do que será escrito nos séculos XVII e XVIII e testemunha o sentido do humanismo que presidiu os princípios da colonização. Desde a "Carta" de Caminha, amplia-se com outros cronistas e com os jesuítas a visão comparativa da terra em relação ao além-mar, enquanto o índio é defendido pelos programas humanísticos jesuítas contra o projeto escravocrata.

Nos primeiros decênios do século XVII, com a decadência da extração de pau-brasil e o malogro das "entradas", firmou-se a economia do açúcar como a base material da Colônia, era, portanto, de esperar que insistissem nessa tônica os escritos de informação e de louvor. O documento mais representativo, no caso, é "Diálogos das Grandezas do Brasil", atribuído ao cristão novo português Ambrósio Fernandes Brandão, que em 1583 veio ao Brasil, estando a seu cargo o recebimento dos dízimos do açúcar em Pernambuco. Possuía uma cultura predominante em ciências naturais e, segundo Jaime Cortesão na apresentação à obra "Diálogos das Grandezas do Brasil”, Brandão dominava a cosmografia de seu tempo, sendo que suas referências religiosas ligam-se ao Velho Testamento.

Com a interrupção de algumas viagens a Portugal, permaneceu no Brasil até 1618, data da composição do livro que escrevera na capitania da Paraíba. Além dessa capitania, só conhecia bem a de Pernambuco, onde morava, e a de Itamaracá, sendo que o autor nunca viajou para o sul do cabo de Santo Agostinho. No entanto, esteve na Paraíba em 1586, início do período de ocupação militar, no qual fora comandante em 1591, tendo perseguido os potiguares; nessa Capitania possuiu engenhos, como o Inobi e o São Gabriel. ${ }^{29}$

Ambrósio Fernandes Brandão, já em 1597, “pretendera provar em Portugal, diante dos governadores, que o Brasil era mais rico e dava mais proveito que todas as Índias Orientais", segundo a apresentação de Jaime Cortesão (apud BRANDÃO, 1943, p. 15). Ignora-se quando faleceu. Já não era vivo quando os holandeses tomaram a Paraíba, e após

\footnotetext{
${ }^{29}$ BRANDÃO, "Diálogos das Grandezas do Brasil”, 1943, p. 09-11.
} 
a Restauração os engenhos dos Brandões caíram em mãos de João Fernandes Vieira, encerrando o legado da família, segundo parecer de Capistrano de Abreu. ${ }^{30}$

Nos "Diálogos das Grandezas do Brasil”, o primeiro dos interlocutores, chamado Brandônio, supõe-se ser o próprio autor da obra, Ambrósio Fernandes Brandão, e Alviano, o segundo interlocutor, chamava-se Nuno Álvares, ambos cristãos novos. Alterando o nome de Brandão para Brandônio, o autor dos "Diálogos" disfarçava-se ao estilo Renascentista, fato relativamente comum aos humanistas da Europa que escreviam tratados de caráter científico, moral ou religioso, tendo vasta repercussão na poesia bucólica e na novela pastoril em Portugal. ${ }^{31}$ Conforme José Aderaldo Castello, Brandônio representa o português fixado na terra, conhecedor de suas possibilidades e que mantém seus interesses imediatistas de exploração. Já Alviano era portador da curiosidade do imigrante recémchegado, comenta e critica o procedimento do colonizador que ainda não sabe aproveitar os recursos naturais para a sua sobrevivência e bem-estar que esta terra lhe proporciona. ${ }^{32}$

Segundo Capistrano de Abreu, Ambrósio Fernandes Brandão conhecia o latim e lera as obras de diversos autores, tais como Aristóteles, Dioscórides, Vatablo e Juntino; tinha conhecimento de História e Geografia, manifesto na precisão e clareza e no modo em que subordina os fatos mais diversos a categorias simples, como quando distribui a vida animal pelos elementos e dispõe as árvores em hortas e jardins. ${ }^{33}$ Para Alfredo Bosi, os Diálogos continuam em informes úteis para o futuro povoador da terra. Para ele,

[...] seria precoce tomar os elogios do reinol cúpido por fatores nativistas em nossa literatura. Mas a insistência em descrever a natureza, arrolar os seus bens e historiar a vida ainda breve da Colônia indica um primeiro passo da consciência do colono, enquanto homem que já não vive na Metrópole e, por isso, deve enfrentar coordenadas naturais diferentes, que o obrigam a aceitar e repensar diferentes estilos de vida. E à medida que o mero conhecimento geográfico vai sendo dominado, abre-se caminho para sentir o tempo que correu, condição primeira de toda historiografia (1996, p. 28).

Os seis diálogos da obra, realizados entre os dois interlocutores, duraram sete dias, sendo que cada diálogo durou um dia e que, no quarto dia, Brandônio não compareceu. A

\footnotetext{
${ }^{30}$ Apud BRANDÃO, “Diálogos das Grandezas do Brasil”, 1943, p. 34.

${ }^{31}$ Ibidem, p. 10.

${ }^{32}$ CASTELLO, “A Literatura Brasileira - origens e unidade”, v. 1, 2004, p. 84.

33 Apud BRANDÃO, "Diálogos das Grandezas do Brasil”, 1943, p. 24.
} 
conversa do primeiro Diálogo trata do relativo abandono da terra, e finaliza-o com a descrição das capitanias desde o Pará ou rio das Amazonas até a capitania de São Vicente.

No Diálogo segundo, Brandônio explica a amenidade do clima do Brasil devido aos "ventos da Guiné”, e também realiza uma discussão sobre "a zona tórrida e sua inhabitabilidade afirmada pelos antigos filósofos, e desmentida pela experiência", conforme nos apresenta Capistrano de Abreu (apud BRANDÃO, 1943, p. 22). Ele estuda as fontes de riqueza do Brasil: lavoura de açúcar, inúmeras formas de comércio, como o trato do paubrasil, os algodões e madeiras. Neste terceiro Diálogo, Ambrósio Fernandes Brandão trata da riqueza, fertilidade e abundância deste Brasil, e encerra-o fazendo exaltada dissertação de suas teorias sobre as raças, a adaptabilidade delas aos diferentes climas e a origem dos americanos. Segundo a apresentação de Jaime Cortesão, no Diálogo terceiro,

[...] brilha com fulgor essa capacidade tão portuguesa para assimilar o exótico e definir as entidades novas, - neste caso, o Brasil. É certo que esta definição vinha de longe. Gandavo e Cardim haviam preludiado o tema. Gabriel Soares de Souza revelara, no Tratado Descritivo, ter uma consciência clara da entidade brasileira, sob o ponto de vista naturalístico, humano e econômico (apud BRANDÃO, 1943, p. 15).

No quarto Diálogo, Brandônio expõe a riqueza do Brasil proporcionada pelo comércio de mantimentos, fala de maneira geral do mel, do vinho, do azeite, da tinta contida nas árvores indígenas e descreve ligeiros quadros da vida vegetal. O quinto Diálogo enumera os animais, subordinados aos três elementos em que vivem: ar, água e terra, sem, no entanto, tratar do fogo. E, finalmente, o último Diálogo se refere aos costumes dos portugueses e aos dos índios, com o qual termina a obra.

Também escreve nesse período de União Ibérica, o cronista Simão de Vasconcelos, que nasceu na cidade do Porto, em Portugal, em 1597. Ele chega ao Brasil em 1616, fixando no Colégio da Bahia, momento em que entra para a Companhia de Jesus. Cursou os estudos de Filosofia e de Teologia, ordenando-se sacerdote e graduando-se mestre de artes. Quando o Brasil enviou à Portugal, em 1641, a Embaixada da Restauração, Simão de Vasconcelos a compôs, junto com o Padre Antônio Vieira e o Marquês de Montalvão. Ocupou quase todos os cargos da Companhia de Jesus no Brasil, entre os quais o de reitor do Colégio da Bahia e do Rio de Janeiro, capitanias que conhecera melhor. Voltou à Bahia em 1642 com o Governador Antônio Teles, que o escolheu para confessor; após vinte anos 
passa a ocupar o cargo de Procurador da Província do Brasil. Voltou a Lisboa, esteve em Roma e retornou ao Brasil em 1663 com o Conde de Óbidos, vindo a falecer em 1671 quando era Provincial no Rio de Janeiro. ${ }^{34}$

Simão de Vasconcelos viveu justamente no período da expulsão dos holandeses de Pernambuco, sendo que a obra "Crônica da Companhia de Jesus" foi escrita em 1663 e foi dedicada ao Rei de Portugal, "a fim de conquistar o poder do inferno, senhoreado neste vasto Império pela Gentilidade Brasílica" ${ }^{35}$, e nela relata os feitos ilustres dessa Companhia, as regiões que descobriram os jesuítas, as nações que sujeitaram e a reputação que adquiriu.

Essa obra trata do início da penetração catequizadora dos missionários, relatando na primeira parte a entrada da Companhia de Jesus no Brasil e os fundamentos religiosos propiciados pelo Padre Manuel da Nóbrega. Na segunda parte é delineada a vida do Padre Anchieta e suas realizações no Brasil. É importante salientar que os anos seguintes à partida de Antônio Vieira para a Europa, em 1661, foram marcados pela legislação caótica a respeito da jurisdição espiritual e temporal, e pela escravidão dos índios, sendo que em 1680 foi criada uma lei que proibiu a escravidão indígena.

Esse livro contém o descobrimento do Novo Mundo, o modo com que o repartiram, os reis de Portugal e Castela, bem como a descrição geográfica de suas terras, rios, portos, cabos, enseadas e serras próximas ao mar, e termina com a descrição das qualidades da terra, do clima, do frescor dos arvoredos, da variedade das plantas, da abundância dos frutos e das ervas medicinais, da diversidade dos animais, e mais prodígios da natureza, com que "o autor dela enriqueceu este novo mundo: poderíamos fazer comparação ou semelhança, de alguma parte sua, com aquele paraíso da terra, em que Deus Nosso Senhor, como em jardim pôs a nosso primeiro pai Adão" (VASCONCELOS, 1977, v. 1, p. 166).

Segundo análise de Sérgio Buarque, em sua obra "Visão do Paraíso", Simão de Vasconcelos pertence aos Seiscentos, a uma era “em que a própria imagem do real só se faz visível, convincente e eficaz, quando se mova segundo os caprichos de uma fantasia barroca" (1996, p. 146).

\footnotetext{
${ }^{34}$ LEITE apud VASCONCELOS, "Crônica da Companhia de Jesus", v. 1, 1977, p. 13.

${ }^{35}$ VASCONCELOS, “Crônica da Companhia de Jesus”, v. 1, 1977, p. 49.
} 
Ao finalizar o século XVII, inicia o período da mineração em Minas Gerais. Segundo informa Andreoni, por pseudônimo Antonil, na obra "Cultura e Opulência do Brasil", um mulato de Curitiba encontrou no rio Tripuí uns granitos cor de aço, que vendeu em Taubaté. Levados ao Rio de Janeiro verificou-se ser ouro finíssimo. Este foi o primeiro descoberto ${ }^{36}$; mas daí seguiram-se inúmeras descobertas nos arredores de Ouro Preto e Mariana, fato que conduziu o desenvolvimento do Brasil Colônia para esta região, abrindo novo centro cultural e político-econômico.

Diferentemente das manifestações literárias do século XVI, de caráter informativodescritivo, que foram denominadas como "literatura pré-colonial", as épocas barroca e arcádica dos séculos XVII e XVIII apresentaram novidades, uma vez que sofreram um processo de assimilação e de diferenciação da herança portuguesa. Na fase do Arcadismo no Brasil, denominada de "neoclássica", no século XVIII, viveram os últimos autores selecionados para esta pesquisa, Basílio da Gama e Frei José de Santa Rita Durão.

Segundo Alfredo Bosi interpreta na obra "História concisa da Literatura Brasileira", a passagem do barroco ao rococó consistiu em uma atenuação dos aspectos pesados dos Seiscentos; nessa mudança prefiguram-se as tendências estéticas do Arcadismo como a busca do natural e do simples. A primeira Arcádia foi fundada em Roma, em 1690, por alguns poetas, cujo emblema era a flauta de Pã, em que tomavam o nome de pastores gregos e romanos, como Teócrito e Virgílio. Participa da composição da poesia árcade, o mito do homem natural cuja forma extrema é a figura do bom selvagem. A luta do burguês culto contra a aristocracia do sangue fez-se em termos da Razão e da Natureza ${ }^{37}$,

Denominador comum das tendências arcádicas á procura do verossímil. O conceito, herdado da poética renascentista, tem por fundamentos a noção de arte como cópia da natureza e a ideia de que tal mimese se pode fazer por graus: de onde, o matiz idealizante que esbate qualquer pretensão de um realismo absoluto. Já os primeiros teóricos da Arcádia propunham mediações entre o natural e o ideal nas suas fórmulas áureas de bom gosto. Para Gian Vincenzo Gravina, cujo tratado Della Ragion Poetica data de 1708, a fantasia deve joeirar os dados da experiência a fim de apreender a natureza última das coisas (a Ideia platônica), que coincidirá com a sua beleza. Segundo esta linha de pensamento, os mitos gregos, que os árcades cultivarão à saciedade, valem como belas aparências do real, do mesmo real que a filosofia cartesiana atinge com os seus conceitos (BOSI, 1997, p. 62).

\footnotetext{
${ }^{36}$ ANTONIL, "Cultura e Opulência do Brasil", 1976, p. 164.

${ }^{37}$ BOSI, "História concisa da Literatura Brasileira", 1997, p. 61-65.
} 
Basílio da Gama nasceu em Minas Gerais, mas vai morar no Rio de Janeiro, onde se forma com os jesuítas, seguindo para a Itália com, o intuito de avançar nos estudos, frequentando a Arcádia Romana como membro efetivo. É preso em Portugal e, prestes a ser exilado para a África, obtém o apoio do Marquês de Pombal. “O Uraguai” foi publicado em 1769 e revela uma fecunda insatisfação com os gêneros literários da tradição e uma súbita mudança de rumo ideológico, que o levaria a denunciar os jesuítas e a apoiar as reformas pombalinas. ${ }^{38}$ Assim, "O Uraguai" procede "a uma expressiva metonimização da estrutura política de nossa história colonial, sem deixar de referir ou retratar pormenores significativos da vida natural do Brasil e dos índios” (TEIXEIRA, 1996, p. 53).

Ainda segundo Ivan Teixeira, "O Uraguai" trata de uma intervenção da cultura européia sobre a americana: “a catequese jesuítica, [...], que assumiu nos Sete Povos feições de escravidão física e moral. Por essa perspectiva, o poema de Basílio problematiza um aspecto importante de nossa condição colonial" (1996, p. 20). Este poema tenta conciliar o louvor a Pombal e ao heroísmo do indígena. À invenção de sua forma instaura uma espécie livre de narrativa em verso. Silva Alvarenga ao comentar a obra "O Uraguai", ressalta a pintura da natureza e indica que as suas principais fontes provêm da "poética retomada a Horácio, Aristóteles e Lucrécio, aos seus divulgadores da época arcádica, nomeadamente Boileau" (CASTELLO, 2004, p. 113).

Segundo Antônio Cândido, na literatura comum, o Arcadismo seria igual ao classicismo francês, mais a herança greco-latina, mais tendências setecentistas que, mesmo ao variarem de país para país, compreendem, de forma geral, o culto da sensibilidade, a fé na razão e na ciência, o interesse pelos problemas sociais. A literatura seria a expressão racional da natureza, buscando, à luz do espírito moderno, uma última encarnação da mimesis aristotélica, buscando a criação artística a partir das sugestões da realidade. ${ }^{39} \mathrm{~A}$ mimesis busca representar as coisas conforme as ideias universais permitem idealizar a natureza, cujos dados reais transcendem graças à fantasia, para formar de todas essas ideias particulares uma ideia universal. Para este autor, no que se refere ao arcadismo,

\footnotetext{
38 TEIXEIRA, “Obras Poéticas de Basílio da Gama”, 1996, p. 19-20.

${ }^{39}$ CANDIDO, "Formação da literatura brasileira - Momentos Decisivos", 2006, p. 44-45.
} 
As regras da retórica e da poética limitavam o indivíduo em benefício da norma, curvando-o à razão natural, banindo as temeridades do engenho, podando na fantasia o estranho e o excêntrico, que se sobrepõem à ordem racional da natureza em vez de espelhá-la. [...] Consequências da imitação e das regras são, no fundo, a perda da capacidade de observar diretamente a vida e uma visão algo superficial tanto da natureza exterior quanto humana. Note-se que a paisagem civilizada, racionalizada, da literatura arcádica é, principalmente, um escorço de paisagem da superfície da terra: árvores, prados, flores, regatos, e os animais pacíficos que nela repousam. Os árcades quase não sentiram a magia do mar, nem do ar, que o Romantismo povoaria de duendes e mistérios. Na própria terra, a sua consciência não teve noção, ou necessidade, do subterrâneo, da caverna. Sentiram as grutas, como as cascatas - ornatos prediletos dos jardins pré-românticos, onde a paisagem epidérmica se dava o luxo de uma simulada energia, como a caverna de Tanajura ou o caramanchão de Lindóia, no Uraguai (CANDIDO, 2006, p. 55).

Nos dizeres de Ivan Teixeira, ao tentar compreender a relação entre desenvolvimento e subdesenvolvimento, tendo como cerne a colonização jesuítica “europeia" e os direitos humanos instaurados, não seria exagero pensar que

[...] a sátira antijesuítica de "O Uraguay" dinamiza ainda mais a literatura de Basílio, evidenciando sua coragem em tomar partido diante de assunto tão delicado como o da perseguição aos inacianos na Europa setecentista. Tal perseguição deveu-se, sobretudo a razões políticas e econômicas, mas não deixou de ter o seu correlato cultural, dado que representou a renovação do ensino e a expansão das Luzes. Com efeito, se os jesuítas do século XVIII não se mostraram capazes de assimilar a doutrina de Galileu, não poderiam mesmo se mostrar mais tolerantes com a de Newton. Portanto, a caricatura de Basílio deve ser entendida como a alegoria de uma posição e não como uma injustiça contra a Companhia de Jesus. [...] A contrapartida dessa atitude é a adesão à mentalidade pombalina, que representava o lado esclarecido do século XVIII e simbolizava o contato com as idéias progressistas da revolução burguesa então em curso. Enfim, o desenho dos jesuítas feito por Basílio é parte de uma ficção engajada, de um protesto literário que não deixa de incluir também uma denúncia contra o próprio partido adotado pelo autor, consubstanciada na descrição comovida do massacre dos portugueses contra os índios guaranis (TEIXEIRA, 1996, p. 20-21).

Adentrando, especificamente, no corpo do poema, no tocante à Natureza, tome-se o início do canto III, em que o exército português, após ter exterminado muitos índios, em sua marcha rumo aos Sete Povos, Gomes Freire de Andrade, o comandante lusitano e herói do poema, "atinge o vale do rio Uruguai, cujas margens são dominadas por extensas campinas de juncos ressequidos” (TEIXEIRA, 1996, p. 34). A Natureza nessa passagem é descrita através de imagens densas e rápidas; não é mero Arcadismo, mas caminha para o 
paisagismo romântico, conforme nos afirma Alfredo Bosi, relação mais direta dos sentidos do mundo: "Enfim, junto a um ribeiro, que atravessa, sereno e manso, um curvo e fresco vale, acharam, os que o campo descobriram, um cavalo anelante e o peito e as ancas cobertos de suor e branca espuma" (GAMA apud BOSI, 1997, p. 73).

Ao verificar a fala dos verdadeiros heróis Cacambo e Cepé, como apologia da vida natural, os valores capazes de inspirar poesia são encarnados pelos nativos. E embora eles se acabem curvando aos pés da Coroa lusa, permanecem como as únicas criaturas dignas de falar em Natureza e em Liberdade:

Gentes da Europa: nunca vos trouxera o mar e o vento a nós. Ah! não debalde estendeu entre nós a natureza todo esse plano espaço imenso de águas. [...] todos sabem que estas terras, que pisas, o céu livres deu aos nossos avós; nós também livres as recebemos dos Antepassados: livres hão de as herdar os nossos filhos (GAMA apud BOSI, 1997, p. 74-75).

Conforme Antonio Cândido, “O Uraguai” desprende um sentimento sereno das coisas naturais, humanizando a paisagem e valorizando o trabalho, "é a paz Virgiliana cantada nas pastoris, em que a presença do trabalho confere dignidade à paisagem, desvinculando-a do pitoresco imediato para vê-la como Natureza, fonte de vida guia da razão” (2006, p. 136). Tendo escolhido a Guerra Guaranítica como assunto do poema, resultou que Basílio tomou aquele ataque sangrento de europeus contra os índios dos Sete Povos como um símbolo do choque desastroso entre a civilização europeia e a cultura primitiva dos americanos, ou seja, a partir de um conflito o poeta realiza uma síntese da história do Brasil. ${ }^{40}$

Na realidade, a Guerra Guaranítica foi uma consequência do Tratado de Madri, de 1750, que desfazia o Tratado de Tordesilhas e reestruturava as posses de Portugal e Espanha no continente sul-americano. Esse Tratado abandonou a ideia do meridiano de Tordesilhas e aplicou o princípio de uti possidetis, em que Portugal cederia à Espanha a Colônia do Sacramento e receberia em troca os Sete Povos das Missões. Tal guerra constou de uma série de expedições dos exércitos desses países contra os índios guaranis que viviam nos Sete Povos das Missões, sob orientação dos padres jesuítas. ${ }^{41}$ Os limites da linha meridiana de Tordesilhas até então vigente, seria substituída por limites naturais,

\footnotetext{
40 TEIXEIRA, “Obras Poéticas de Basílio da Gama”, 1996, p. 35.

${ }^{41}$ Ibidem, p. 45.
} 
tomando por base as paisagens mais conhecidas, tais como a origem e curso dos rios e os montes mais notáveis.

Deste modo, perante a fábula de "O Uraguai”, em seu Canto primeiro, a Companhia de Jesus, dominada pela ambição, espalhou aldeias por toda a América do Sul, onde fundou os Sete Povos das Missões, dirigidas por padres espanhóis e habitadas por índios guaranis, que viviam em escravidão, que os jesuítas logravam disfarçar com a máscara da religião e da bondade. Os índios tinham os seus hábitos sociais destruídos pelos jesuítas e eram explorados em seu trabalho, cujo excedente produzido era enviado para a sede da Companhia de Jesus, em Roma. ${ }^{42}$

Porém, em 1756, com a chegada do general Cataneo ao Novo Mundo houve a imediata junção dos exércitos portugueses e espanhóis. Todavia, a narrativa cuida apenas da tropa portuguesa, que encontra um batalhão de índios, entre os quais Cepé e Cacambo, que, em discurso inflamado, denunciam a crueldade dos brancos em seus ataques aos índios, afirmam não reconhecer os reis da Europa, já que sua única autoridade eram os padres jesuítas.

Gomes Freire que representava o rei de Portugal, diz que os índios seriam livres sempre, mas deveriam entregar aquelas terras e conviria pensar antes de guerrear, senão provocaria um grande derramamento de sangue indígena. Em seu discurso, Cacambo exclama que gostaria que a América não fosse povoada por europeus, e que não foi por acaso que a natureza os separou pelo oceano. Mas, Cepé profere discurso dizendo que aquelas terras sempre pertenceram aos índios e, se houvesse justiça na Europa, os índios seriam inocentados. No entanto, Gomes Freire aceita o desafio de Cepé e julga inevitável a guerra. Ao findar o conflito, os portugueses prosseguiram rumo aos Sete Povos. ${ }^{43}$

Através de sua selvagem bravura de guerreiro, o índio é conclamado a proteger o colonizador. Deste modo, Basílio da Gama se distancia do caráter especificamente informativo dos cronistas anteriores e coloca o indígena no centro dos acontecimentos, ofertando-lhe um papel mais proeminente do que fora apresentado anteriormente. Mas, numa calma noite, a Cacambo, em perturbado sono, aparece-lhe o fantasma de Cepé, tal como morrera no combate, exortando-o a atear fogo e destruir o acampamento do invasor,

\footnotetext{
42 TEIXEIRA, "Obras Poéticas de Basílio da Gama”, 1996, p. 38.

${ }^{43}$ Ibidem, p. 40-41.
} 
O índio habitador de quando em quando

Com estranha cultura entrega ao fogo

Muitas léguas de campo: o incêndio dura,

Enquanto dura, e o favorece o vento.

Da erva, que renasce, se apascenta

O imenso gado, que dos montes desce;

E renovando incêndios desta sorte

A Arte emenda a Natureza, e podem

Ter sempre nédio gado e o campo verde.

[...] Era alta a noite, carrancudo e triste

Negava o Céu envolto em pobre manto

A luz ao Mundo e murmurar se ouvia

Ao longe o rio, e menear-se o vento.

Respirava descanso a natureza (TEIXEIRA, 1996, p. 218).

O general Gomes Freire domina o incêndio provocado por Cacambo, e aproxima-se dos Sete Povos. Ao escalar uma altíssima montanha que o separava dos índios, do seu cume tem uma bela visão da natureza:

Assim quem olha do escarpado cume

Não vê mais do que o Céu, que o mais lhe encobre

A tarda, e fria névoa, escura e densa.

Mas quando o Sol de lá do eterno, e fixo

Purpúreo encosto do dourado assento,

Co'a criadora mão desfaz, e corre

$O$ véu cinzento de ondeadas nuvens,

Que alegre cena para os olhos! Podem

Daquela altura, por espaço imenso,

Ver as longas campinas retalhadas

De trêmulos ribeiros; claras fontes,

E lagos cristalinos onde molha

As leves asas o lascivo vento.

Engraçados outeiros, fundos vales, E arvoredos copados, e confusos,

Verde teatro, onde se admira quanto

Produziu a supérflua Natureza (TEIXEIRA, 1996, p. 228).

Mesmo que José Basílio da Gama tenha-se arrependido das ofensas proferidas à Companhia de Jesus, essa obra é considerada um ataque ao projeto jesuíta no Brasil Colônia e ajusta-se as perseguições que o Marquês de Pombal promoveu contra aquela ordem religiosa até a sua expulsão definitiva dos domínios de Portugal.

Segundo José Aderaldo Castello, o sentimento da paisagem é algo novo e expressivo na poesia da época, e Basílio da Gama "soube ser de fato independente em face das limitações bucólicas do Arcadismo, sem deixar de ser árcade” (1969, p. 171). Ao se 
distanciar da estética árcade, Basílio participou do processo de renovação da literatura setecentista. "O Uraguai" despertou novos interesses nos poetas brasileiros da época, "tendo influenciado de modo particular a formação dos mais jovens, como Silva Alvarenga e Alvarenga Peixoto, sem deixar de influir também na poesia épica dos mais velhos, como Cláudio Manuel da Costa e Santa Rita Durão” (TEIXEIRA, 1996, p. 22).

Finalizamos a apresentação dos cronistas com o árcade José de Santa Rita Durão, que nasceu em 1722, em Cata-Preta, arraial de Nossa Senhora do Inficionado, próximo a Mariana, em Minas Gerais. Ainda na infância muda-se para o Rio de Janeiro, onde estudou no Colégio dos Jesuítas e, em 1731, parte para Portugal, nunca mais retornando ao Brasil. Foi professor da Ordem de Santo Agostinho, em Lisboa. Graduou-se e doutorou-se em Teologia pela Universidade de Coimbra. Em 1758 passa a ser membro da Academia Litúrgica, no mesmo ano em que critica os jesuítas. Em 1759 pregou um conhecido sermão contra a Companhia de Jesus, a fim de atrair a simpatia do Marquês de Pombal. Contudo, no decorrer de sua vida se arrepende de sua posição contra os jesuítas, fato que culminará com a sua fuga de Portugal.

Em 1781 publica "Caramuru - poema épico do descobrimento da Bahia” que compreende "a história do Brasil, os ritos, tradições, milícias dos seus indígenas, como também a natural, e política das colônias” (CANDIDO, 2006, p. 189), ao descrever uma natureza grandiosa aos reis da França. Mas será, segundo Alfredo Bosi, "uma corrente oposta à de Basílio, voltada para o passado jesuítico e colonial, e em aberta polêmica com o século das luzes" (1997, p. 75).

O modelo adotado por Santa Rita foram “Os Lusíadas”, de Camões, evidentemente percebido na escolha da estrofe heroica, na divisão do poema em dez cantos, em oitavas camonianas e na divisão do poema em invocação, proposição, dedicatória, narrativa e epílogo, bem como outros recursos da narrativa épica, sobretudo o maravilhoso cristão, abrangendo a história do Brasil do século XVI ao XVIII.

Segundo Antonio Candido, "as tentativas épicas foram a debilidade e o anacronismo mais flagrante do século XVIII, tão aferrado ao senso das proporções e ao culto das formas naturais" (2006, p. 187). Nesse contexto, Sérgio Buarque de Holanda assinala que a epopeia portuguesa, na segunda metade do século XVIII, é "muito menos um fenômeno europeu do que americano", chamando a atenção para o conjunto de textos épicos 
americanos que superam em importância os épicos portugueses do período, principalmente "O Uraguai", de Basílio da Gama, o "Vila Rica” de Cláudio Manoel da Costa e o “Caramuru”, de Santa Rita Durão. ${ }^{44}$

Em "Caramuru", a ocupação do território baiano se constitui em pretexto para que Santa Rita Durão trate de nossa flora e fauna, da divisão administrativa do Brasil colonial, notificando particularidades das capitanias, das nações indígenas, com seus hábitos e costumes, bem como das diversas guerras que Portugal travou com franceses e holandeses pelo controle do território ao longo da costa. Ainda que a ação do poema se situe no século XVI, Durão recorre a sonhos e presságios dos personagens para compendiar toda nossa história até fins do século XVIII, através do qual

Surpreende a riqueza de dados sobre a vida de inumeráveis nações indígenas, seus costumes, hábitos alimentares e familiares, regras políticas e formas de religiosidade, bem como a infinidade de plantas, flores, pássaros, animais, peixes que surgem ao longo do poema, tanto mais se notarmos que Santa Rita Durão só viveu no Brasil até os nove anos de idade. É portanto natural que seu nome seja dos mais importantes para compreendermos a criação de um certo imaginário, uma certa idéia de Brasil, que opera com o engrandecimento das nossas riquezas naturais e culturais para a afirmação de nossas potencialidades históricas. [...] Mas é, sobretudo pela figura do índio construída no poema que Santa Rita Durão tem seu nome sempre lembrado em nossa história literária, sendo figura central para a discussão da temática do 'indianismo' entre nós (POLITO apud DURÃO, 2005, p. XXII).

A obra "Caramuru" tem como episódio central "a legenda de Diogo Álvares Correia, apelidado o Caramuru, no seu relacionamento com índios, cujos hábitos, costumes, valores, guerras são minuciosamente descritos" (CASTELLO, 2004, p. 123). O significado específico do termo "caramuru", palavra, de origem tupi, é moreia. Caramuru foi o nome que os indígenas deram a Diogo Álvares por este ter escapado a nado de um naufrágio nas costas da Baía de Todos os Santos, em 1510. Ao que parece, foi Santa Rita Durão que fixou a lenda de que Diogo Álvares teria maravilhado os indígenas com um tiro de espingarda, passando o vocábulo a significar também "Filho do Trovão", "Dragão do Mar" e "homem de fogo". 45

\footnotetext{
${ }^{44}$ POLITO apud DURÃO, "Caramuru”, 2005, p. XX-XXI.

${ }^{45}$ CUNHA, "Dicionário histórico das palavras portuguesas de origem tupi”, 1998, p. 103.
} 
Conforme diz Antônio Cândido, em sua obra "Formação da Literatura Brasileira Momentos Decisivos", por ser homem pertencente a sua época, Durão talvez sentisse atrás disso a presença de uma lei natural, que traria aos homens paz e justiça, independentemente da revelação. Mas como procura captar sob as lendas e costumes indígenas uma longínqua fonte comum, que as reduzisse ao tronco bíblico, não lhe é difícil assimilar essa ordenação da vida e essa presença do bem a uma reminiscência gravada na memória coletiva:

[...] pois quem lhes transfundiu estes conhecimentos, se não a antiga tradição dos tempos diluvianos e a harmonia que estas tradições têm com a natureza? A religião aparece como coextensão do natural e do revelado, assim como para muitos dos seus contemporâneos a lei do mundo e da sociedade se definia pela coextensão do natural e do racional. Chave dos fenômenos e dos acontecimentos, a revelação divina tudo anima. A Providência guia os homens e em especial o branco na conquista das terras e gentes alheias à religião de Cristo. E toda a ação se esclarece na medida em que é referida pelo autor a este padrão (CANDIDO, 2006, p. 194).

Mesmo que Santa Rita Durão diferencie o homem branco do indígena ao tratar da revelação divina, ele procura reconhecer a existência do sentimento religioso do indígena que está inserido na coextensão do natural e do revelado espírito de Deus, fato que foi veementemente questionado, mal interpretado e por vezes negado nas obras dos cronistas e viajantes dos séculos XVI e XVII.

Segundo Simpson, Santa Rita Durão teve grande influência no Romantismo, principalmente, na obra de Gonçalves Dias, em virtude do tema indianista; "Caramuru" apresenta a descrição dos costumes indígenas e das terras brasileiras. Fiel aos modelos clássicos, propõe a incorporação dos índios à fé cristã, em “"que o indígena seja ali empregado, e que à sombra das leis tranquilo esteja' - tanto quanto a aproximação do mundo natural à lei racional” (DURÃO, apud SIMPSON, 2007, p. 18).

Santa Rita Durão reflete sobre temas centrais do período, como as formas de ocupação europeia na América, as características da colonização portuguesa no Brasil, o ideal do herói civil, pacífico e cristão, o problema da conversão do gentio ao cristianismo diante da ameaça protestante, particularmente calvinista, e o tema do canibalismo. $\mathrm{O}$ autor finaliza o poema com o Canto $\mathrm{X}$, que começa com uma visão profética de Catarina, proveniente da Virgem Maria. Sendo sagrados reis dos povos baianos, Caramuru e Paraguaçu, transferem imediatamente sua realeza para D. João III. 
Este período em que viveu Santa Rita Durão coincide com a efetivação do mandato contra os jesuítas, subscrito em 1758 pelo cardeal Francisco de Saldanha no qual o Marquês de Pombal declara-os traidores e os desnaturaliza. Expirava o governo de José I e, extinguindo-se o poderio do Marquês de Pombal, pela primeira vez uma rainha ascendia ao trono português, e em 1777 foi firmado o Tratado de Santo Ildefonso, que delimitava a maior parte de nossas imensas e conflituosas fronteiras internas. E também o Brasil, nesse momento, está próximo de se tornar independente de Portugal.

Antes de adentrarmos a análise das representações da Natureza feitas pelos cronistas e viajantes do Brasil Colonial, faremos nos próximos capítulos, uma análise do conceito de "natureza" na história do pensamento ocidental, buscando conhecer os fundamentos teórico-filosóficos subjacentes a tais interpretações. Com efeito, conceitos antigos e medievais estão na base das elaborações teóricas dos viajantes e cronistas. Seu universo mental mergulhava raízes no mundo clássico e cristão medieval. Importa-nos, assim, compreendê-los melhor. 


\section{I - O conceito de natureza na história da Filosofia até o século XVIII}

A ideia de natureza começa a ser construída no Ocidente a partir de um amplo embasamento mitológico. Uma das entidades veneradas desde os tempos mais remotos é a Terra-Madre, que está atribuída a origem das coisas. É no sentido de "nascer", que se encontra presente o próprio germe da ideia de natureza. ${ }^{46}$ Physis, em grego indica "o ato do nascer e do crescer, mas também a origem, o lugar de onde as coisas nasceram e nascem, a realidade que serve de pressuposto à experiência. É sinônimo de "ghénesis", vocábulo "teogônico" por excelência, já utilizado por Homero e Hesíodo para designar o nascimento das coisas" (CASINI, 1975, p. 24).

Segundo Kerényi (2004) a mitologia ocidental contém muitas histórias acerca do princípio das coisas. A mais antiga, talvez, seja aquela a que se refere Homero, quando chama Oceano de "a origem de tudo". Oceano era um deus-rio, e, desde o momento em que tudo se originou dele, "continuou a fluir até a orla mais extrema da terra, fluindo de volta sobre si mesmo num círculo. Os rios, as nascentes e as fontes - na verdade, todo o mar saem continuamente de sua corrente ampla e poderosa" (2004, p. 25). Quando Zeus passa a governar o mundo, Oceano fica com o fluxo circular, e a tarefa de abastecer as nascentes, os rios e o mar ficou delegada a Zeus. ${ }^{47}$ No mito grego, “Oceano é a imagem da indistinção e da indeterminação primordial” (BRANDÃO, 2004, p. 197).

A importância da motivação poética de Homero reside em que ela se compõe de motivos míticos, históricos ou retirados da natureza. Segundo Kranz, o mundo de Homero é uma admirável unidade do suprassensível e do sensível, como se nestas antíteses se manifestara à lei una da Natureza. ${ }^{48}$

Segundo Hesíodo, o início de tudo, o que primeiro existiu foi o Caos e depois apareceu Terra, Gaia, que é a mãe universal, através da qual, florestas, montanhas, grutas subterrâneas, ondas do mar e vasto céu nasceram. Após o surgimento de Caos e Terra aparece Eros, que expressa um impulso no universo. Assim o mundo se constrói a partir de Caos, Gaia e Eros, e em seguida Urano e Pontos, que são ao mesmo tempo forças naturais e divindades. Gaia é a terra onde andamos e, ao mesmo tempo, é uma deusa. Após a geração

\footnotetext{
${ }^{46}$ CASINI, "Filosofias da Natureza", 1975, p. 21.

${ }^{47}$ KERÉNYI, “Os Deuses Gregos”, 2004, p. 25.

${ }^{48}$ KRANZ, “La Filosofía Griega”, 1962, p. 12.
} 
de Gaia e Urano, surgirá o reinado de Crono, que cumprirá uma etapa fundamental no nascimento do Cosmo, em que Noite e Dia se sucedem regularmente. ${ }^{49}$

A "Teogonia" de Hesíodo ordenou e fixou as gerações divinas e fincou as estacas da organização do cosmo. O poeta faz o deslocamento do Caos, da massa informe, como diz Ovídio nas "Metamorfoses", para Zeus, isto é, das trevas para a luz, da matrilinhagem para a patrilinhagem. Zeus não se apresenta como criador, mas como ordenador. ${ }^{50}$ Assim como podemos reafirmar neste trecho:

Precisamente, na Teogonia, Hesíodo enuncia a versão dominante da origem dos homens e dos deuses: uns e outros nasceram de uma só mãe, da Terra, Géia. Como a espécie humana, os deuses gregos pertencem à totalidade do mundo. Os donos do universo físico na são potestades transcendentes nem deuses criadores, nem dispõem soberanamente das criaturas do céu, da terra e do mar (DETIENNE \& SISSA, 1990, p. 18).

Nas epopeias de Homero e Hesíodo, Zeus está acima de todo o desenrolar da obra, de maneira que parece assemelhar-se a Jeová. Contudo, Zeus governa apenas a relação com o homem; com efeito, em nenhum momento da história do pensamento grego aparece a ideia de um livro de estatutos morais, revelados por um deus pessoal de uma esfera de existência anterior e fora das leis da natureza. ${ }^{51} \mathrm{O}$ próprio Zeus é o senhor dos ritmos cronológicos: manipula o raio e a chuva, cuida da sucessão ordenada das estações e dos dias. Com o compromisso de velar pelo mundo, governar os homens e reger a natureza, inúmeras divindades manifestaram sua majestade, exercendo tarefas. ${ }^{52}$

A história dos homens começa no momento em que Zeus impera, num lugar da Grécia chamado Mecona, onde deuses e homens vivem juntos numa terra de riqueza em abundância, onde tudo cresce espontaneamente. É a paz, é um tempo antes do tempo, onde os homens permaneciam jovens, não havia nascimento, nem doença, nem sofrimentos, não precisavam lavrar a terra, tinham à disposição todos os alimentos, lá, "a natureza oferece de forma espontânea todos os bens da vida [...], eles conhecem a felicidade" (VERNANT, 2000, p. 57).

\footnotetext{
${ }^{49}$ VERNANT, “O universo, os deuses, os homens”, 2000, p. 17-21.

${ }^{50}$ BRANDÃO, "Mitologia Grega", 2004, p. 160-163.

${ }^{51}$ CAMPBELL, “As Máscaras de Deus - mitologia ocidental”, 2004, p. 153.

${ }^{52}$ DETIENNE \& SISSA, “Os Deuses Gregos - A vida cotidiana”, 1990, p. 59 e 142.
} 
Essa ideia presente nas representações antigas marcará profundamente o mundo ocidental e os textos dos viajantes e cronistas do Brasil Colonial, ainda que por reelaboração de autores latinos.

Num cosmos repleto de deuses, o homem grego não separa o natural e o sobrenatural, estes permanecem ligados um ao outro. Não que se trate de uma religião da natureza, em que os deuses gregos sejam personificações de fenômenos naturais. Pois, o raio, a tempestade, os altos cumes não são Zeus, mas de Zeus; os deuses gregos são Potências. ${ }^{53}$ Entretanto, "nem todos os deuses homéricos revestiram-se das formas humanas, há os que permaneceram como forças da natureza” (BRANDÃO, 2004, p. 133).

Também compõe este breve relato referente aos fundamentos mitológicos, de caráter cosmogônico, os mistérios, principalmente os de Elêusis; o dionisismo, que introduz uma experiência do sobrenatural; e, por fim, aquilo que é chamado orfismo, na qual encontramos uma tradição de livros sagrados, atribuídos a Orfeu e Museu, que comportam teogonias e cosmogonias. ${ }^{54}$ Para os órficos, na origem, o Princípio, Ovo primordial ou Noite, exprime a unidade perfeita, mas o Ser degrada-se à medida que a unidade se divide criando formas distintas. $O$ orfismo, na diversidade de suas formas, pertence essencialmente ao helenismo tardio, mas, nos séculos V e IV a.C., já circulavam teogonias que os filósofos pré-socráticos conheceram.

O orfismo ensinava a crença na preexistência e imortalidade da alma, a existência de uma culpa original, a reencarnação e a necessidade de libertar-se da matéria para recuperar a felicidade perdida. Além de ideias em comum com o orfismo, o pitagorismo se caracterizava por suas especulações matemáticas e pelo simbolismo atribuído aos números, considerados a essência das coisas. ${ }^{55}$ Assim, vemos que "a imagem da natureza construída pela escola exerceu influência incalculável tanto sobre a astrologia como sobre a astronomia" (CASINI, 1975, p. 28-29). Há um hino órfico em relação a natureza, datado aproximadamente, do século II: “Ó Natureza, deusa mãe de todas as coisas, mãe de mil astúcias,/ Celeste antiga divindade fecunda, rainha/ Que doma tudo e jamais é domada,/ Que tudo governa e vê" (Apud HADOT, 2004, p. 47).

\footnotetext{
${ }^{53}$ VERNANT, "Mito e Religião na Grécia Antiga”, 2006, p. 4-9.

${ }^{54}$ Ibidem, p. 70-71.

${ }^{55}$ COSTA, "Santo Tomás de Aquino e a filosofia cristã", 1993, p. 7-8.
} 
Estas cosmogonias homéricas, hesiódicas e órficas que, a princípio, parecem distantes da formulação e do desenvolvimento do conceito de "Natureza", assumirão, durante a história do pensamento ocidental, o papel de fundamentos de sistemas filosóficos em que tal conceito se apresentará de envolta com elementos míticos.

O período designado como Antiguidade Clássica foi dominado pela problemática do conhecimento da natureza, nele mergulham as raízes das posteriores incursões filosóficas do espírito europeu. A natureza aparece aos homens como textura de símbolos, que o logos tem de interpretar. ${ }^{56}$ Foi nas colônias gregas da Ásia Menor que ocorreram as primeiras manifestações de um pensamento dotado de exigência de compreensão racional que, depois de produzir as cosmogonias homéricas, hesiódicas e órficas, eclodiu sob a forma de filosofia. Dentro desse espírito surgiram as primeiras concepções filosóficas ocidentais, propostas pela escola de Mileto, tendo como temática a investigação dos primeiros princípios, expressa num conjunto de tratados que se remetem ao estudo da natureza. ${ }^{57}$

O cerne desta filosofia, em seu momento inicial, foi a preocupação cosmológica, isto é, a de sondar as causas e os fundamentos do mundo natural e do universo. Os filósofos cosmológicos estavam à procura de algo que persistisse através das mudanças, daí surge a designação de "sempre-novo" e "imortal". É significativo que, num fragmento Anaxágoras use os mesmos epítetos, "sempre-novo" e "imortal", aplicados por Anaximandro à substância primordial única, e que os associe com o termo physis, natureza. Essa passagem é tão importante para nosso presente objetivo que vamos citá-la na íntegra: ${ }^{58}$

Feliz aquele que da investigação (historía), recebeu conhecimento (máthesis) sem instigar o sofrimento dos cidadãos, nem ações injustas; mas, observando a ordenação da sempre-nova natureza imortal, uniu o onde e o como.

Para esses, jamais o estudo se aproxima das obras vergonhosas (BURNET, 2006, p. 27).

\footnotetext{
${ }^{56}$ GOMES, "Filosofia Grega Pré-Socrática", 1994, p. 23.

${ }^{57}$ LAN y JULIÁ, "Los Filósofos Presocráticos”, 1986, p. 66.

${ }^{58}$ BURNET, “A Aurora da filosofia grega”, 2006, p. 26.
} 
Esse fragmento é uma prova de que, no século V a.C., o nome physis (natureza) foi dado àquele algo permanente de que era feito o mundo. Isso é perfeitamente compatível com a história dessa palavra, cujo sentido original parece ter sido o "material" de que tudo é feito. Esses primeiros cosmólogos, que estavam à procura de algo "imortal e semprenovo", expressariam essa ideia dizendo que havia uma physis de todas as coisas,

Quando essa idéia foi abandonada, sob a influência da crítica eleática, a antiga palavra continuou em uso. Empédocles afirmou que havia quatro dessas matérias primitivas, cada qual com sua própria phýsis, enquanto os atomistas acreditaram haver um número infinito delas, ao qual também aplicaram o termo (BURNET, 2006, p. 28).

Portanto, physis é o termo-chave na transição do mundo de Homero e Hesíodo para o mundo dos physiológoi, o mundo que era cosmos. A beleza da physis é que ela mostra o que havia na concepção tradicional do mundo que deu aos physiológoi os materiais para sua nova construção, o cosmos eles tiveram de inventar. A physis eles já encontraram pronta no esquema conceitual que herdaram. Tudo o que precisavam era dar-lhe novo uso. Para os physiológoi a natureza permanece o princípio inviolável de explicação que tudo inclui, isto é, a ordem que torna o nosso mundo um cosmos é imanente à natureza. ${ }^{59}$

Forma-se com isso a ideia de que "assim, a natureza é concebida como uma ordem regida por leis universais, tomando forma a ideia de Kosmos" (CASINI, 1975, p. 25). O que Heráclito havia negado quando escreveu "este mundo, o mesmo para todos, nenhum homem ou deus o fez", Platão transforma-o no primeiro princípio da cosmologia no Timeu. Ele oferece uma cosmogonia teológica, se propõe a descrever a origem do cosmos como obra de um deus que toma a matéria em um estado caótico e a molda à semelhança de um modelo ideal. Esse deus está fora da natureza, ele mesmo não é um membro do sistema de entidades interagentes que constitui a natureza. ${ }^{60}$

Paralelamente, desde o século VI a.C., verificou-se na Grécia uma revivescência da vida religiosa, averiguada no culto a Dioniso, que passou a constituir o núcleo da religiosidade órfica, que acreditava na imortalidade da alma, em que, depois de purificada, ela aspiraria a retornar à sua pátria celeste. No entanto, Pitágoras, realizou uma modificação

\footnotetext{
${ }^{59}$ VLASTOS, "Universo de Platão", 1987, p. 21.

${ }^{60}$ Ibidem, p. 26.
} 
fundamental na doutrina órfica; em lugar de Dioniso pôs a matemática, cuja finalidade era a de descobrir a harmonia, a proporção e a beleza, que preside à constituição do cosmo. ${ }^{61}$

Porém, houve uma reformulação na concepção cosmológica do pitagorismo efetuada por Zenão de Eléia, que foi a do "intervalo" que separaria as unidades; assim, o número das unidades de extensão "crescia" e cada coisa tendia a tornar-se infinita. Essa reformulação foi a principal contribuição dos atomistas ao desenvolvimento da filosofia, cuja escola teve início com Leucipo, mas teve sua plenitude com Demócrito de Abdera. Partindo de colocações do eleatismo, Leucipo e Demócrito teriam concluído que o movimento existe, por que o não-ser também existe. Desse modo, afirma-se a existência do vazio, em que se moveriam os átomos, fazendo com que os maiores ficassem mais expostos aos impactos dos demais, que poderia então ocasionar o aparecimento de turbilhões: seria esse o começo de um universo. ${ }^{62}$ Para Demócrito, o céu e os astros são necessários devido a uma causa provinda do turbilhão, que constitui a harmonia do cosmos, em que os vegetais e os animais são gerados pela natureza. ${ }^{63}$ Posteriormente as teses atomistas irão ressurgir com Epicuro e Lucrécio, no período helenístico da cultura grega.

Importante contribuição a ideia de natureza é oferecida por Heráclito através do aforismo "a natureza ama ocultar-se", em que ele desenvolve a ideia do segredo da natureza. A physis para Heráclito designa tanto a "ação expressa pelo verbo phyesthai: nascer, crescer, avançar, quanto o seu resultado" (HADOT, 2004, p. 38).

Já, Parmênides extraiu das primeiras cosmogonias o seu arcabouço lógico, centralizado na noção de unidade, manifestada por uma razão absoluta, identificada com o discurso de uma deusa. E segundo Casini, Empédocles aceita o princípio monista parmenidiano com o qual não é aceitável o nascimento e a morte do Ser, mas, sim, a presença de uma pluralidade de substratos primordiais, as quais seriam às quatro substâncias materiais que dominaram a física durante dois milênios. ${ }^{64}$

Mas, a autoridade de Pitágoras, Parmênides, Empédocles ou Anaxágoras, as suas abordagens mitologizantes e subjetivistas dos mistérios da natureza entraram em crise na Atenas do século V, com o desabrochar da sofística, uma vez que teorizaram a inutilidade

\footnotetext{
${ }^{61}$ PRÉ-SOCRÁTICOS, “Os Pensadores”, cap. 1, 1973, p. 8.

${ }^{62}$ Ibidem, p. 22.

${ }^{63}$ ARISTÓTELES apud GOMES, "Filosofia Grega Pré-Socrática", 1994, p. 190.

${ }^{64}$ CASINI, "Filosofias da Natureza", 1975, p. 33.
} 
da investigação naturalista e exercitaram a sua ironia contra as supremas noções do Ser e da Natureza formuladas pelos "fisiólogos". No mesmo sentido atuaram exigências contrárias de conservação religiosa e ideológica, que denunciavam o materialismo e o ateísmo latentes em suas ideias. A polêmica platônica tendia a separar os dois planos da realidade que apareciam sobrepostos, a imagem conexa da natureza culminava numa religião pitagorizante que Platão considerou dever impor por lei aos governantes da Cidade. ${ }^{65}$

Assim, na filosofia platônica se estabelecerá uma importante transformação do conceito de Natureza, porém, antes de adentrarmos especificamente o pensamento de Platão, torna-se indispensável uma breve exposição do pensamento de Sócrates, que se beneficiou da atmosfera cultural do século de Péricles, e que, graças a sua proteção, acorreram para Atenas os sofistas, que fundamentam todo o conhecimento na convenção a partir das impressões sensíveis, em que "o homem é a medida de todas as coisas", como afirma Protágoras ao exprimir o relativismo da sofística. ${ }^{66}$ Mas, Sócrates reage a este relativismo sofístico e, alicerçado em pressupostos órfico-pitagóricos, cria uma nova concepção de alma, que passou a dominar a tradição ocidental, e que veio a influenciar Platão, que "no se cansa nunca de insinuar que él es el heredero espiritual de dos grandes hombres que le precedieron Sócrates y Pitágoras”, conforme Alfred E. Taylor (1946, p. 8).

A explicação do mundo físico, desde os milesianos, convertia-se na procura de uma situação primordial que justificaria a situação presente do cosmo. Com Platão essa índole da investigação é substituída pela perspectiva que propõe as ideias como causas intemporais para os objetos sensíveis. Perfeitas e imutáveis, as ideias constituiriam os modelos aos quais as coisas materiais seriam apenas cópias imperfeitas e transitórias. Em sua obra "Mênon", Platão expõe a doutrina de que o intelecto pode apreender as ideias porque também ele é incorpóreo, isto é, a alma humana, antes do nascimento, teria contemplado as ideias enquanto seguia o cortejo dos deuses. ${ }^{67}$

O mito da caverna remete a outros mitos que constituem uma versão dos mitos órficos, que Platão aceitou a seu modo. Nem o mundo da natureza escapa à sugestão do mito. Só é possível conhecer a natureza à medida que esse conhecimento é reminiscência de modelos ideais, em que a natureza provém do Demiurgo que a edificou com base num

\footnotetext{
${ }^{65}$ CASINI, "Filosofias da Natureza", 1975, p. 35.

${ }^{66}$ SÓCRATES, “Os Pensadores”, 1972, p. 35-36.

${ }^{67}$ PLATÃO, “Os Pensadores”, 1972, p. 58.
} 
plano, através do qual "o verdadeiro conhecimento surge da recordação dos germes da verdade que a alma conserva no seu íntimo" (CASINI, 1975, p. 38). Tanto as obras da natureza quanto as imagens dessas obras foram criadas pela arte divina, o que veio a significar para Platão que o conhecimento do mundo físico deve ser construído com o instrumental matemático. ${ }^{68}$

No século IV a.C. Platão reorganizou uma "nova" concepção do cosmos e a reformulou segundo o padrão de sua própria metafísica, idealista e teísta. Na obra "Timeu", Platão trata da ordem do mundo, mostra-nos que os princípios dessa ordem regem também o homem, mas esta se funda na própria natureza do universo, pelo que se impõe começar pela origem do universo, investigando-se as causas de sua harmonia e passando, daí, para a origem do homem e a harmonia que deve reger a sua alma. ${ }^{69}$ Platão afirma que o Cosmos foi gerado por um artesão divino, que o moldou com base na desordem originária. Não temos nada semelhante à criação ex nihilo da tradição judaico-cristã, que se afirmará no período medieval; pode-se dizer que, "antes da intervenção demiúrgica, o substrato caótico possuía analogia com o mundo dos atomistas" (ABRANTES, 1998, p. 32).

Assim, para Platão, a physis, ou melhor, as obras da natureza são as obras de uma arte divina, deste modo, jamais poderá haver ciência verdadeira, porque os processos naturais são conhecidos somente pelos deuses e também porque eles acham-se em perpétua transformação. ${ }^{70}$

Toda a explanação cosmológica do "Timeu" desenvolve-se sob certos pressupostos fundamentais, de natureza metafísica, e toda a estrutura da realidade é de natureza matemática, inscrita na corrente de pensamento que começa no século VI a.C. unindo cosmologia, geometria e filosofia, provenientes das cosmologias pré-socráticas. Assim, a corrente platônica viu-se envolvida pela necessidade de um comprometimento original entre a especulação racional sobre a natureza e a geometria. ${ }^{71}$

Nenhum outro diálogo de Platão foi alvo de tantos comentários quanto o "Timeu"; dos comentários antigos, são famosos os de Calcídio, Proclo e Plotino, foi principalmente através deles que a Idade Média conheceu o "Timeu", cuja influência permanecerá até o

\footnotetext{
${ }^{68}$ PLATÃO, “Os Pensadores”, 1972, p. 60-62.

${ }^{69}$ BITAR, "Introdução”, in: PLATÃO, “Timeu”, 2001, p. 24-25.

${ }^{70}$ HADOT, “O véu de Ísis”, 2004, p. 42-43.

${ }^{71}$ BITAR, "Introdução", in: PLATÃO, “Timeu”, 2001, p. 40-42.
} 
Renascimento. A vigência desse escrito, enquanto explicação da natureza e no que concerne à organização astronômica do universo, foi encerrada com a Nova Astronomia e com a fundação da ciência moderna, e isso a partir de Galileu, que inaugurou um novo caminho, “o da própria concepção da estrutura da natureza" (BITAR apud PLATÃO, 2001, p. 44-45). E, segundo Casini:

[...] a misteriosa correspondência entre os ritmos da natureza e os destinos humanos, a harmonia e beleza do cosmo visto como obra de arte são os aspectos da herança 'platonizante' [...]. Sobreviveu na Idade Média em simbiose com o misticismo neoplatônico, [...] que reapareceu e fundiu-se com a tradição hermética nas filosofias renascentistas da natureza (1975, p. 41).

Esse breve relato da imagem platônica da natureza é suficiente para averiguarmos em que aspectos Aristóteles se aproxima de Platão e em que aspectos ele o critica. É importante referenciar que não há em Aristóteles uma criação do cosmo, que é considerado eterno. Para o estagirita, há uma pluralidade de naturezas no cosmo, cada qual determina especificamente movimentos naturais tendentes à realização de determinados fins, constituídos pelas naturezas distintas das coisas. Uma natureza é ao mesmo tempo, causa eficiente e causa final de um movimento natural específico. ${ }^{72}$

Para Aristóteles, o conjunto do universo físico estaria dividido em duas regiões distintas: a sublunar, constituída pelos quatro elementos herdados da cosmologia de Empédocles, a água, o ar, a terra e o fogo, caracterizada por movimentos retilíneos e descontínuos, em que cada um dos elementos teria seu "lugar natural"; e a supralunar, constituída por uma "quinta essência", o éter, e caracterizada por movimentos circulares e contínuos. ${ }^{73}$

Como já afirmavam os pitagóricos, o mundo supralunar estaria constituído por uma sucessão de esferas cada qual se movimentando em função da esfera imediatamente superior, que atua como motor. Essa sucessão de motores-móveis terminaria num primeiro motor, este imóvel, paira acima do universo, movendo-o como causa final, e que

\footnotetext{
72 ABRANTES, "Imagens de natureza e de ciência", 1998, p. 34-35.

73 ARISTÓTELES, “Os Pensadores”, 1973, p. 82-83.
} 
Aristóteles chama de Deus, que não cria o Universo e nem sequer o conhece. ${ }^{74} \mathrm{O}$ Deus de Aristóteles é eterno como a natureza que para sempre tende da potência ao ato. ${ }^{75}$

Será através do diálogo "Sobre a Filosofia", que Aristóteles apresenta uma concepção cosmológica de cunho finalista e teológico, em que o universo é explicado como um organismo que se desenvolve graças a um dinamismo interior, um princípio imanente que Aristóteles denomina "natureza". Porém, será através dos chamados Corpus aristotelicum, que Aristóteles rejeitará a transcendência dos arquétipos platônicos, considerando-os uma desnecessária duplicação da realidade sensível. ${ }^{76}$

Essa fundamentação metafísica da noção de natureza possui implicações epistemológicas, já que

[...] as condições antecedentes do movimento natural (o que se refere à "natureza" como princípio de movimento) não são empiricamente determináveis, já que não podem ser objeto de percepção sensível. O movimento é, obviamente, perceptível, mas não o princípio do movimento, que é a natureza (physis) (ABRANTES, 1998, p. 41).

Podemos dizer que há um ponto de convergência entre Platão e Aristóteles, a tese de que são as formas ou essências que constituem o objeto do conhecimento. E as naturezas das coisas refletem uma ordem cósmica, uma hierarquia que, por ser imutável, pode ser objeto de um conhecimento verdadeiro. ${ }^{77} \mathrm{~A}$ "Natureza" para Aristóteles significa:

1) A gênese das coisas que crescem [...]. 2) A parte imanente de uma coisa que cresce, da qual provém o seu crescimento; 3) A origem do movimento primeiro que é imanente a cada coisa natural em virtude da sua própria essência. [...]. 4) 'Natureza' também significa o material primeiro de que consiste ou é feito qualquer objeto natural, sendo aquêle relativamente informe e dotado de uma potência imutável. [...]. 5) 'Natureza' significa a essência dos objetos naturais, como entre os que denominam natureza ao tipo primordial de composição, ou como Empédocles que diz: "Outra natureza não tem tudo que existe, senão a mistura e a separação dos misturados, e natureza não passa de um nome que os homens lhe dão". Por isso dizemos das coisas que são ou vêm a ser por natureza, [...]. 6) Por uma extensão deste significado de 'natureza', toda essência em geral é assim chamada, porquanto a natureza de uma coisa é uma espécie de essência (1989, p. 114-115).

\footnotetext{
${ }^{74}$ ABRANTES, “Imagens de natureza e de ciência”, 1998, p. 38-39.

${ }^{75}$ CASINI, "Filosofias da Natureza", 1975, p. 50.

${ }^{76}$ ARISTÓTELES, “Os Pensadores”, 1973.

${ }^{77}$ ABRANTES, "Imagens de natureza e de ciência", 1998, p. 40 e 42.
} 
Deste modo, é evidente que "natureza" é a essência das coisas, uma origem do movimento, e neste sentido, é a origem do movimento dos objetos naturais, quer em potência, quer em ato. ${ }^{78}$ Submetida a uma ordem e penetrada de finalidade, a Natureza reproduz periodicamente os fenômenos porque são "habituais". Ele classifica os fenômenos para esboçar uma História Natural. ${ }^{79}$

Outra importante corrente filosófica que formulará uma "nova" concepção da Natureza é o estoicismo, ao pretender que a moral encontrasse seu fundamento numa filosofia da natureza. Para Zenão de Cício (336-264 a.C.), dever-se-ia "viver em harmonia com a natureza", em que "a mesma razão que governa o mundo deve regular também nossas ações", sendo essa razão imanente à natureza. ${ }^{80}$

Os estoicos e os epicuristas teriam efetuado um retorno ao monismo dos présocráticos. No entanto, a concepção estoica de natureza é distinta da epicurista. Enquanto aquela é dinamista e espiritualista, essa se aproxima do mecanicismo moderno: "para os estoicos, toda mudança era entendida à maneira de um desenvolvimento biológico. Eles retomam o hilozoísmo dos primeiros filósofos gregos, que viam a natureza (physis) como um princípio dinâmico" (ABRANTES, 1998, p. 45), o qual reflete uma unidade fundamental entre matéria e espírito. Para os estoicos, Natureza e Deus se identificam, como nos diz Sêneca: "O que é a Natureza senão o próprio Deus e a razão divina imanente ao mundo em sua totalidade e em todas as suas partes?" (Apud HADOT, 2004, p. 46).

Já, os epicuristas admitiam a existência de deuses, mas eles não interferiam no curso da natureza. Epicuro foi influenciado pela filosofia natural dos atomistas, enquanto que os estoicos o forma pela concepção de physis jônica, sobretudo, de Heráclito, os estoicos "divinizaram a Natureza" ou "naturalizaram Deus". ${ }^{81}$

Os estoicos teriam dado um passo decisivo ao assimilar o conceito de éter ao de pneuma, que era considerado o espírito animador, o sopro vital nos vegetais, nos animais e nos homens. Uma vez que eles,

[...] eliminaram a divisão entre mundos sublunar e supralunar de Aristóteles, fazendo o pneuma se estender indiferentemente por todo o cosmo. Assim fazendo, os estóicos teriam antecipado os 'éteres' do século XVII - como os de

\footnotetext{
78 ARISTÓTELES, “Metafísica”, Livro V, 1989, p. 115.

${ }^{79}$ LENOBLE, "História da ideia de Natureza", 1969, p. 93.

${ }^{80}$ ABRANTES, "Imagens de natureza e de ciência”, 1998, p. 43.

${ }^{81}$ Ibidem, p. 45.
} 
Descartes, Boyle e Newton. [...] O determinismo estóico é consequência de um panteísmo em que o mundo é integrado e racional. Deus é a razão seminal do mundo. [...] a semente possui 'armazenados' todos os eventos futuros do desenvolvimento [...], orientada para a perfeição e a unidade do todo (ABRANTES, 1998, p. 50-52).

A ideia de Natureza vai transformar-se incessantemente ao sabor da luta entre o "idealismo" platônico e o "materialismo" de Epicuro. A obra "De natura rerum" de Lucrécio vai dar-lhe a forma que reterá até o início da época moderna, ${ }^{82}$ nesta obra é celebrada uma esplêndida invocação à Vênus, que é, numa só pessoa, a natureza criadora e a mãe do seu povo, a quem o poeta apresenta a sua homenagem:

Ó Vênus criadora, que por sob os astros errantes povoas o navegado mar e as terras férteis em searas, por teu intermédio se concebe todo o gênero de seres vivos e, nascendo, contempla a luz do sol: por isso de ti fogem os ventos, ó deusa; de ti, mal tu chegas, se afastam as nuvens do céu; e a ti oferece a terra diligente as suaves flores, para ti sorriem os plainos do mar e o céu em paz resplandece inundado de luz. [...] Visto que sozinha vais governando a natureza e que, sem ti, nada surge nas divinas margens da luz e nada se faz de amável e alegre. [...] Dá pois a meus versos, ó Vênus divina, teu perpétuo encanto. [...] Vou começar a expor-te a essência do céu e dos deuses, e revelar-te-ei os princípios das coisas, donde as cria a natureza e as faz crescer e as alimenta, e para onde de novo as leva a mesma natureza, já exaustas; a estes princípios, na exposição da doutrina, damos nós o nome de matéria, de corpos geradores e de sementes das coisas; e até lhes chamamos corpos primordiais, porque deles, como princípio, tudo surge (LUCRÉCIO, 1973, p. 39-40).

Robert Lenoble (1969, p. 115) nos traz sua reflexão da obra do poeta, "Mãe e madrasta, [...] a Natureza de Lucrécio escreve em letras imensas no Cosmos inteiro as hesitações e ambivalências do poeta. A sua física permanece uma curiosa mistura de mecanicismo e de finalidade”.

Essa ideia de Lucrécio será retomada no Renascimento, e também, neste período, ressurgirão outras concepções que estiveram latentes desde a Antiguidade, que formarão, juntamente com o aristotelismo da escolástica, o pano de fundo da Revolução Científica. Portanto, as imagens aristotélicas de natureza e de ciência tornaram-se hegemônicas no final da Idade Média, e foi basicamente contra elas que se insurgiram, no século XVII, Bacon, Descartes, Galileu, Boyle e Newton. ${ }^{83}$

\footnotetext{
${ }^{82}$ LENOBLE, "História da ideia de Natureza”, 1969, p. 103-104.

${ }^{83}$ ABRANTES, "Imagens de natureza e de ciência”, 1998, p. 42-43.
} 
Diante da expansão do helenismo, que era a cultura predominante no surgimento do cristianismo, cuja filosofia helênica estava marcada pelas preocupações religiosas e místicas características do neoplatonismo de origem órfico-pitagórica, o próprio cristianismo acabou sofrendo um processo de helenização. No entanto, as principais conclusões da filosofia cristã coincidem com os dados da revelação, que parte do pressuposto de que o conhecimento que o homem possui dos princípios racionais vem de Deus, criador do universo. ${ }^{84}$ Deste modo, quando o pensamento judaico-cristão se insere na tradição helênica, forma-se a filosofia que perpassará por toda a Idade Média. ${ }^{85}$

O conceito da criação, em oposição aos velhos mitos começa pela frase: "No princípio criou Deus o céu e a terra”, para João, o logos é o próprio Deus, é o verbo pelo qual foi feito o mundo. Ao lado desse prólogo, foram as epístolas paulinas que mais influenciaram a cristandade; mas, ainda que o prólogo de João fosse diferente da doutrina platônica das Ideias, ele encorajou os pensadores cristãos a intercalar no seu contexto a teoria de Platão. ${ }^{86}$ Assim, "a filosofia cristã restringe o determinismo natural, reduzindo às leis de uma razão superior a aparente desordem da natureza" (GILSON, 2006, p. 453).

A natureza divinizada dos antigos cede lugar a uma natureza passiva no Cristianismo composta por criaturas cuja existência e ordenação depende essencialmente dos desígnios divinos, que criou a natureza e que pode intervir alterando a ordem "natural" dos fenômenos. Nada restou das "essências" e "naturezas" que se atualizam de forma necessária; se há "essências", só Deus as conhece, cabendo ao homem somente conhecer as regularidades fenomênicas, mas, jamais as causas dessas regularidades. ${ }^{87}$

Numa breve passagem é necessário salientar importantes incursões na filosofia, como as de Plotino (205-270 d.C.), que acrescenta os "graus do ser" a filosofia platônica ${ }^{88}$, cuja obra "Enéadas", nos relata que a Natureza tem sua origem no Bem e no Belo ${ }^{89}$, bem como as de Orígenes (185-255 d.C.), que firma a existência de um cosmos ordenado e harmonioso dado que, em Deus o espírito se identifica a natureza, e podemos chamá-Lo de "mônada", que é incorpórea e por isso independente de todo espaço e lugar. Orígenes

\footnotetext{
${ }^{84}$ COSTA, "Santo Tomás de Aquino e a filosofia cristã", 1993, p. 07-11.

${ }^{85}$ GILSON, "O Espírito da Filosofia Medieval", 2006, p. 445-446.

${ }^{86}$ GILSON y BOEHNER, "História da Filosofia Cristã", 2008, p. 13-15.

${ }^{87}$ ABRANTES, "Imagens de natureza e de ciência", 1998, p. 58-59.

${ }^{88}$ TAYLOR, "El Platonismo", 1946, p. 17-18.

${ }^{89}$ PLOTINO, “Tratados das Enéadas", 2000, p. 100.
} 
afirma que Deus criou um mundo perfeito, sendo que, a matéria criada por Deus, se transforma nesta admirável obra de arte que é o nosso mundo. ${ }^{90}$

No entanto, uma influência filosófica ainda mais clara sobre o Pensamento Ocidental se estabeleceu através das obras de Dionísio Pseudo-Areopagita, que inspirarão toda a teologia mística cristã que se supõe terem sido escritas no século V ou VI. ${ }^{91}$ Foi por intermédio dele, que muitos elementos neoplatônicos penetraram no Ocidente, cujo efeito é um cosmos santo proponente da hierarquia celeste ${ }^{92}$, "em que o infinito passa ao finito. Ao primeiro círculo pertencem os serafins, os querubins e os tronos; ao segundo, as dominações, as virtudes e as potestades; ao terceiro, o principado, os arcanjos e os anjos, sendo Deus o ponto de partida e destino de todas as coisas" (CASSIRER, 2001, p. 16-17).

A Idade Média propriamente dita, inicia-se sob o influxo do neoplatonismo agostiniano. Santo Agostinho (354-430 d.C.), relata que toda a natureza é obra de Deus. Há a forma de que se reveste exteriormente a matéria, que está ao alcance de qualquer artífice, mas há outra forma cuja eficiência causal é interior e provém da misteriosa vontade de uma natureza viva que produz as formas naturais dos corpos e as próprias almas, que só se pode atribuir a Deus. ${ }^{93}$ A natureza e todo o cosmos são perfeitamente ordenados, tudo é regido pela lei natural. ${ }^{94}$ A Natureza, para Deus, será sempre o que ele fez. Assim, "a filosofia cristã manda os prodígios e as maravilhas da natureza, tão caros aos antigos, juntarem-se aos monstros na ordem irracional que ela supera. Um milagre cristão não é um monstro. [...] porque, é a vontade do Criador que define a natureza" (GILSON, 2006, p. 462).

Segundo José Silveira da Costa “dada à profundidade filosófico-teológica de sua obra, nenhum outro pensador do Ocidente cristão exerceu tanta influência por tão longo tempo como Santo Agostinho” (1993, p. 14-15). Somente no século XIII, quando Santo Tomás optou por Aristóteles em lugar de Platão, é que as ideias agostinianas começaram a perder a preponderância. ${ }^{95}$

Se a noção da filosofia deriva principalmente de Agostinho, o método que Erígena emprega provém de Dionísio, que, como este, concebe o Universo como um cosmos

\footnotetext{
${ }^{90}$ GILSON y BOEHNER, "História da Filosofia Cristã”, 2008, p. 56-58 e 73.

${ }^{91}$ PLOTINO, “Tratados das Enéadas”, 2000, p. 179.

${ }^{92}$ GILSON y BOEHNER, "História da Filosofia Cristã”, 2008, p. 115-116.

93 AGOSTINHO, “A Cidade de Deus”, 1993, p. 1147.

${ }^{94}$ GILSON y BOEHNER, "História da Filosofia Cristã”, 2008, p. 187.

${ }^{95}$ COSTA, "Santo Tomás de Aquino e a filosofia cristã", 1993, p. 14-15.
} 
hierarquicamente ordenado. Seu intuito é “descobrir o processo metafísico capaz de explicar o modo em que à natureza se origina de Deus e a Ele retorna" (GILSON y BOEHNER, 2008, p. 233). Para Erígena a divisão da natureza é o ato pelo qual Deus se exprime e se revela a si próprio, como natureza criada e criadora no que toca às criaturas. Do exposto se segue que o universo das coisas criadas deve ser concebido como um sinal ou símbolo, pelo qual Deus se dá a conhecer. Considerado em sua subsistência eterna nas ideias divinas, o corpo se diz substância ou essência; visto em sua existência corporal, chama-se natureza. ${ }^{96}$

O universo medieval caracteriza-se por seu simbolismo religioso, é um imenso globo material com dois polos espirituais, em que a matéria superior vai até o céu e a inferior até o inferno, sendo que os homens ocupam um posto intermediário; para o homem medieval, a essência das coisas se oculta sob as aparências, daí a impossibilidade de explicá-las a partir dos dados sensíveis. As precárias informações sobre a ciência da natureza derivam, quase sem exceção, das enciclopédias de Isidoro de Sevilha e Rabano Mauro, que são os representantes clássicos deste gênero de explicação,

[...] diz a Escritura que Adão deu aos animais os nomes que lhes convinham. Nestes nomes esconde-se o segredo de suas essências e de suas forças místicas. Donde a importância da etimologia para se conhecer a natureza das coisas. A consideração das coisas em si passa a um plano secundário: nos Bestiários e Lapidários medievais enumeram-se animais e objetos que jamais existiram. $\mathrm{O}$ interesse primário do homem medieval não é a classificação sistemática das coisas, mas o conhecimento das forças místicas, ocultas em seus nomes (GILSON y BOEHNER, 2008, p. 279-280).

Há uma transição contínua das correspondências analógicas para as propriedades simbólicas, que lhes foi impressa pelo próprio Criador. Deste modo, Deus se manifestou pela Sagrada Escritura e pela Natureza. Com o passar do tempo, a interpretação religiosa cederá lugar ao estudo das próprias coisas. Estimulado pela física aristotélica, o interesse renovado pela investigação da natureza formará a base de um novo desenvolvimento, que originará a ciência moderna. ${ }^{97}$

No século XII, por obra de Abelardo (1079-1142), “a lógica aristotélica tinha sido objeto de renovado interesse, provocando as primeiras inquietações por parte das

\footnotetext{
${ }^{96}$ GILSON y BOEHNER, "História da Filosofia Cristã", 2008, p. 241-242.

${ }^{97}$ Ibidem, p. 280-282.
} 
autoridades eclesiásticas, temerosas de um possível surto de racionalismo que poderia ameaçar a tranquilidade das consciências cristãs" (COSTA, 1993, p. 15). Mas, só no século XIII, quando a "Física" e a "Metafísica" de Aristóteles chegam ao Ocidente, irá acontecer uma verdadeira revolução nos meios acadêmicos medievais.

No entanto, o período conhecido como a Alta Escolástica foi algo mais que um aristotelismo cristianizado, uma vez que Aristóteles sofreu o influxo da filosofia árabe, da tradição agostiniana e da Patrística. Porém, a história da filosofia cristã dos séculos XIII e XIV é essencialmente um debate em torno da filosofia aristotélica, que fornecia certos conceitos que pareciam adequados à interpretação dos fenômenos da natureza.

Para a Idade Média, a Universidade abrangia os grandes centros das Ordens religiosas, que por meio da teoria da luz, Grosseteste procura explicar a criação do universo, já que na Bíblia, no primeiro dia, criou Deus o céu e a terra, e depois disse: façase a luz. Com isso, temos os dois princípios, matéria e forma, suficientes para explicar a gênese deste mundo. Ele foi o grande mentor da Escola Franciscana de Oxford e a teoria da luz passa a desempenhar um papel decisivo em quase toda a Escola Franciscana. ${ }^{98}$

Tanto a Ordem dos franciscanos, quanto a dos dominicanos, fundadas no início do século XIII por São Francisco de Assis (1182-1226) e por São Domingos (1170-1221), assumiram posições bem definidas nesse conflito de ideias. Os franciscanos liderados por São Boaventura (1221-1274), “aliaram-se às autoridades da Igreja na defesa da tradição agostiniana. [...] Já os dominicanos, primeiro sob a orientação de Alberto Magno e, depois, de Santo Tomás, defendiam a possibilidade de conciliar os princípios da filosofia aristotélica com as verdades da fé cristã” (COSTA, 1993, p. 16-17).

Mas, foi a partir do século XIII, que as obras de Aristóteles se livraram dos agregados platônicos, através do labor dos dominicanos Alberto Magno e Santo Tomás de Aquino (1225-1274), que tinham a impressão de que redescobriam a natureza em si mesma e não que tinham uma coleção de símbolos que incluíam verdades teológicas.

Na Idade Média, a totalidade do que chamamos "natureza" é o sistema de fatos inter-relacionados, revelados pelos sentidos e está, segundo Platão, distante do real conhecimento. Se a natureza está sempre em formação, nossas conjecturas são unicamente provisórias e nunca podem obter uma finalidade similar a da matemática e a da ética. A

${ }^{98}$ GILSON y BOEHNER, "História da Filosofia Cristã", 2008, p. 373-374. 
natureza é um sistema de símbolos, e ascendemos à verdade aprendendo a passar dos símbolos a realidades simbolizadas não sensíveis. O simbolizado pela natureza se atribui a Deus, que é o princípio da natureza e das formas que ela nos revela. Logo, Deus pode ser conhecido, unicamente, mediante inadequadas manifestações de si mesmo. O homem, decaído, se engana especialmente ao decifrar os símbolos pelos quais Deus se revela. Deus também se nos revela pelas Escrituras por meio de metáforas e analogias tomadas da natureza. É assim que a natureza se converte na chave para descobrir os "hieróglifos" divinos das Escrituras. Entretanto, a teoria criada por Alberto e Tomás é oposta a este platonismo cristianizado. Já não se considera a natureza como "linguagem divina", e sim como a obra de um artífice. Em vez de falarmos de uma mensagem direta de Deus na natureza, podemos unicamente esperar leves indícios do artista em sua obra. ${ }^{99}$

No século XIII, o neoaristotelismo de Tomás converteu a Ética de Aristóteles na causa principal da filosofia moral oficial da Igreja católica. No entanto, como cristão, Tomás tem de abandonar a concepção aristotélica de uma deidade absorta em sua própria contemplação. Daí a importância de mostrar que Deus, ao conhecer seu próprio ser, conhece todas as outras coisas, posto que sejam efeitos de seu próprio ser. Esta concepção é característica dos neoplatônicos e Tomás a aceita de Proclo, por intermédio de Dionísio. ${ }^{100}$

Em consonância com as tradições cristãs, São Tomás alega que aquele que possui um real saber acerca da natureza jamais a identificará com Deus, nem exagerará a necessidade interna dos processos naturais e nem deixará de subordinar o ser humano ao influxo necessitante dos astros. Mas, no entanto, há algo inteligente pelos quais todas as coisas naturais se ordenam ao fim, a que chamamos Deus. ${ }^{101}$

No término da Idade Média, à escolástica “dos aristotélicos” se contrapõe Nicolau de Cusa (1401-1464), que se associa à torrente mística que desde os tempos de Dionísio permeia os domínios da teologia cristã. Para Nicolau, Deus criou o mundo de acordo com as leis da aritmética, da geometria, da música e da astronomia, daí podermos usar das coisas sensíveis e dos conhecimentos matemáticos para penetrar nos mistérios de Deus. ${ }^{102} \mathrm{Se}$ em

\footnotetext{
99 TAYLOR, “El Platonismo”, 1946, p. 40-53.

${ }^{100}$ Ibidem, p. 137-141.

${ }^{101}$ GILSON y BOEHNER, "História da Filosofia Cristã”, 2008, p. 452.

102 Ibidem, p. 563-564.
} 
Dionísio a "divinização" se processa por força do princípio hierárquico, tal divinização é, para o cusano, um ato único no qual o homem se coloca em relação direta com Deus. ${ }^{103}$

O que existe é um único cosmos, homogêneo em si, e com isso descarta-se a oposição de valor entre o mundo sublunar e o celestial. De tais considerações decorre uma segunda ponderação que destitui o sistema cosmológico de Aristóteles de todo valor de verdade, pois à substância celeste perfeita deve corresponder um movimento perfeito, no entanto, o cosmos não representa uma esfera perfeita; assim Nicolau chega às considerações da nova cosmologia. No pensamento medieval, o tema da redenção significa a libertação do mundo; mas, Nicolau de Cusa não reconhece mais tal separação entre o homem e a natureza. O reino da graça e o reino da natureza estão inter-relacionados, surgindo o espírito da humanidade, como algo que é criador e criatura. É como se, com isso, o dogma do pecado original tivesse perdido as forças que exerceu sobre todo o pensamento medieval.

No universo organicamente inter-relacionado de Nicolau de Cusa, "é por firmarem suas próprias naturezas que os vários componentes do universo contribuem para a perfeição do todo" (KOYRÉ, 2006, p. 23). Seu mundo já não é o cosmos medieval, mas ainda não é o universo infinito dos modernos.

A partir do instante em que a Idade Média fora levada por Aristóteles a reconhecer a importância da Lógica, tornou-se inevitável que o pensamento levasse os homens a não mais se contentarem com os princípios da física aristotélica, adotados pela Escolástica, mas, ao contrário, observarem o próprio mundo perceptível, procurando formar opiniões novas, independentes ou até contrárias à Religião e à autoridade de Aristóteles sobre o universo. Um dos primeiros a escolher esse caminho foi Roger Bacon, que pretendia estudar o mundo não somente em suas relações com Deus e a Revelação, mas também, por meio de pesquisas na própria Natureza, através do empirismo e do método experimental. ${ }^{104}$

Segundo Eduardo A. Navarro num artigo denominado "Uma Sinopse da Literatura de Viagem no Brasil dos séculos XVI e XVII", nos atesta que com a profunda divisão no seio da Cristandade, ocasionada pela Reforma Protestante, em 1517, perdia-se a unidade religiosa do Ocidente. A Igreja Católica encontrava-se mergulhada em profunda crise desde

\footnotetext{
${ }^{103}$ CASSIRER, "Indivíduo e cosmos na filosofia do Renascimento", 2001, p. 05-25.

${ }^{104}$ MILLER, “Os Jesuítas - seus segredos e seu poder”, 1932, p. 434.
} 
o início do século XVI. O Concílio de Trento e a fundação da Companhia de Jesus viriam em resposta ao grande desafio representado pela Reforma Protestante” (NAVARRO, p. 01).

A Igreja Católica procurava defender a universalidade da sua concepção do Universo contra as tendências que procuravam destruir a unidade do pensamento da Idade Média. Coube aos jesuítas, em grande parte, a missão de fazer respeitar em todos os lugares os cânones do Concílio de Trento. Quando esse Concílio se reuniu em 1545, para restabelecer a unidade do pensamento católico frente à concepção do Universo, havia exatamente dois anos que Copérnico, em sua obra "De revolutionibus orbium caelestium" destruíra justamente esta harmonia reinante entre a ciência e a fé. Exprimira Copérnico em sua obra a convicção de que não era a terra e sim o Sol o que constituía o centro imóvel, em torno do qual o Universo gravitava. Ora, essa opinião minava os alicerces todos da concepção aristotélica e cristã do Universo.

Certamente que os padres estavam dispostos a aceitar as inovações, desde que fossem enquadradas dentro de certos limites, mas não podiam admitir a teoria de Copérnico. Galileu, corroborando com a nova interpretação copernicana, diz crer que os fenômenos naturais que verificamos por demonstrações comprovadas não podem ser invalidados por considerações baseadas nas passagens da Bíblia, pois as suas palavras não estão ligadas a normas tão estritas quanto o estão todos os fenômenos da Natureza. ${ }^{105}$

Os jesuítas procuraram criar um equilíbrio entre a herança da Idade Média e o espírito da época moderna, de modo que não estivesse em contradição com as exigências da Igreja, no qual se encontrariam conciliadas a fé dogmática e o impulso para o conhecimento racional, característica dos tempos modernos, despertado pelo Renascimento.

Somente nos séculos XVI e XVII se formaria um cenário de modificações nas imagens de natureza herdadas da Antiguidade e adaptadas pelos medievais. Ocorreu, então, não somente uma revolução astronômica, mas também uma revolução na "física terrestre", que culminou com a nova mecânica galilaico-newtoniana e pode ser vista como uma decorrência da revolução astronômica e cosmológica, já que a física de Aristóteles não é compatível com o heliocentrismo e com a infinitude do universo. ${ }^{106}$ Segundo Koyré, no prefácio a obra "Do Mundo Fechado ao Universo Infinito", essas mudanças parecem ser

\footnotetext{
${ }^{105}$ MILLER, “Os Jesuítas - seus segredos e seu poder”, 1932, p. 438.

${ }^{106}$ ABRANTES, "Imagens de natureza e de ciência", 1998, p. 53.
} 
redutíveis à destruição do cosmos, perpetrada através da "substituição da concepção do mundo como um todo finito e bem ordenado, [...], por um universo indefinido ou mesmo infinito, não mais unido por subordinação natural" (2006, p. 2).

A aceitação da lógica aristotélica pela escolástica medieval e sua fusão com o mundo cristão levou, depois, à adoção de um sistema cósmico original, hierarquicamente graduado, levando os habitantes imortais de suas esferas em gradação maravilhosa até ao Coelum empyreum. Essa concepção da Escolástica manteve-se viva no seio do Jesuitismo ainda além da Idade Média. No século XVI, justamente na época em que as ideias pregadas por Inácio de Loyola começavam a se propagar, alastrava-se pela Europa a Reforma de Lutero e Calvino, e, dentro em breve, a doutrina inaciana iria tornar-se o sinal característico do catolicismo na luta contra as inovações protestantes. ${ }^{107}$

Para os Gregos, o princípio do eterno retorno, teorizado por Aristóteles e pelos estoicos e pitagóricos, governa a sua concepção do tempo ciclicamente repetido e está em oposição à concepção cristã do tempo linear projetado para o futuro que "rumam agora para o 'Novo Mundo', e querem dar 'novos mundos ao Mundo"” (CRISTÓVÃO, 1999, p. 37).

Deste modo, segundo Miller "repercutia uma tendência para demolição do edifício aristotélico, e os novos sábios renascentistas rebaixavam Aristóteles a Platão, somente os jesuítas, a despeito de todas as concepções da época moderna guardavam fidelidade a Aristóteles" (1932, p. 190).

Mas, no entanto, a concepção da infinitude do universo que se origina com os gregos, através dos atomistas, passou a ser mais bem conhecida por intermédio do redescoberto Lucrécio, revalorizada por Giordano Bruno, que declara que o espaço do universo infinito lucreciano é perfeitamente homogêneo. Bruno substitui o espaço aristotélico pelo espaço geométrico valorizando a concepção copernicana, atingindo frontalmente o cosmos medieval. Mas foi Nicolau de Cusa quem rejeitou a concepção cosmológica medieval e afirmou a infinitude do universo que culminaram na transferência para o universo da pseudo-hermética caracterização de Deus como "uma esfera cujo centro está em toda parte e cuja circunferência está em parte alguma” (KOYRÉ, 2006, p. 20).

A astronomia copernicana removeu a Terra do centro do mundo e colocou-a entre os planetas, destruindo os "alicerces da ordem cósmica tradicional, com sua estrutura

${ }^{107}$ MILLER, “Os Jesuítas - seus segredos e seu poder”, 1932, p. 44-45. 
hierárquica e sua oposição qualitativa entre o domínio celeste do ser imutável e a região terrestre ou sublunar de mudança e corrupção" (KOYRÉ, 2006, p. 28-29). Copérnico utiliza as técnicas matemáticas elaboradas por Ptolomeu, mas vai buscar em Platão e nos pitagóricos as causas dos fenômenos que atribuía movimentos circulares à Terra esférica.

Deste modo, a filosofia natural do Renascimento estaria em ruptura com o aristotelismo escolástico e com o naturalismo renascentista. Quando Koyré reconhece a importância, para a Revolução Científica, do resgate do platonismo realizado pelo Renascimento, é para destacar o papel que a matemática passou a desempenhar no estudo da natureza. ${ }^{108}$

A destruição do cosmos e a perda da situação central da Terra levaram à perda pelo homem de sua posição privilegiada; contudo, esse deslocamento da Terra não foi sempre sentido como uma degradação, uma vez que, Nicolau de Cusa afirma sua promoção ao plano dos astros nobres e Giordano Bruno considerou que movimento e mutação são sinais de perfeição. Não há limites que nos possam usurpar a infinidade das coisas ou privar-nos dela, porque do infinito é engendrada uma abundância sempre renovada de matéria. ${ }^{109}$

Foram através destes fundamentos que Demócrito e Epicuro sustentavam que tudo através do infinito sofria renovação e servia de base à modernidade, ao propiciar a emergência de novas modalidades explicativas que causaram mudanças nas nossas imagens de natureza. Assim, o uso sistemático da experimentação como método só foi possível a partir do século XVI, com a rejeição de uma suposta teleologia nos processos naturais e a sua substituição pela emergência de uma imagem mecanicista de natureza. ${ }^{110}$

No decorrer do século XVII é incorporada esta imagem mecânica da natureza à construção de teorias científicas, visto que, na Antiguidade, prevaleceram as metáforas do organicismo. $\mathrm{O}$ que possibilitou essa mudança nas imagens de natureza ao ingressarmos na modernidade, foi "a emergência, com o Cristianismo, de uma nova concepção da relação Deus-Natureza" (ABRANTES, 1998, p. 56).

A concepção moderna de "lei natural" que surge no século XVII tem uma longa história, desde as origens arcaicas da noção de lei na Antiguidade, adquirindo diversas conotações religiosas, teológicas e jurídicas no período medieval, como em Galileu, em que

\footnotetext{
${ }^{108}$ ABRANTES, “Imagens de natureza e de ciência”, 1998, p. 77.

${ }^{109}$ KOYRÉ, "Do Mundo Fechado ao Universo Infinito", 2006, p. 40-41.

${ }^{110}$ ABRANTES, "Imagens de natureza e de ciência", 1998, p. 22.
} 
o conceito moderno de lei já estava presente; mas, foi, sobretudo, com Descartes que se fixa de modo sistemático o uso moderno do conceito de "lei física", associando as "leis naturais" à imutabilidade divina. "Deus criou a natureza e 'imprimiu' suas leis à matéria, numa particular concepção da relação Deus-natureza” (ABRANTES, 1998, p. 63).

$\mathrm{Na}$ concepção moderna, já se encontra, em Francis Bacon, completamente estabelecido que o conhecimento científico tem por objetivo aumentar o poder do homem sobre a natureza, e que o método para a obtenção de conhecimento dos fenômenos naturais é experimental, como também analisa Abrantes (1998, p. 67).

A doutrina cartesiana de uma ação paralela de uma substância mecânica e outra espiritual foi desenvolvida por Leibniz, que estabeleceu uma diferença rigorosa entre espírito e matéria, ele aceita um reino das causas eficientes e um reino das causas finais, numa "harmonia pré-estabelecida". Deste modo, os jesuítas dispensaram à obra de Leibniz uma grande benevolência, uma vez que, as suas concepções se encontravam em oposição às doutrinas de Lutero e Calvino. Será Leibniz o que está mais próximo da filosofia aristotélico-escolástica do pensamento cristão. ${ }^{111}$

A discussão, sobretudo no que concerne a Descartes, diz respeito à ordem do mundo e à passagem do caos à ordem. Para ele, as leis da natureza "bastarão para fazer que as partes do caos consigam desenredarem-se por si mesmas, dispondo-se em bela ordem”. A pretensão de poder descrever a passagem do caos à natureza e da confusão primogênita à atual ordem do mundo será reprovada pelos cartesianos. Na verdade, esse processo é narrado pela Bíblia e emana de Deus. Apenas o mundo compreendido após sua criação e antes de sua dissolução final, poderia ser objeto da indagação racional, assim, jamais o homem poderia conhecer o plano divino. ${ }^{112}$

A chamada revolução científica do século XVII consistiu na substituição de imagens de natureza da Antiguidade, que foram transformadas pelo período medieval, por novas imagens. E quando se falava em explicação, significava indicar como a matéria em movimento causa os fenômenos observados, rejeitando tanto as "formas substanciais" da Escolástica quanto às "qualidades ocultas" do Renascimento. E como nos traz Abrantes (1998, p. 83), ao “acrescentar 'forças' à ontologia tradicional da filosofia mecânica - o que

\footnotetext{
${ }^{111}$ MILLER, “Os Jesuítas - seus segredos e seu poder”, 1932, p. 154-158.

112 LEIBNIZ, "Protogaea", prefácio dos tradutores, 1997, p. 22.
} 
fez Newton - constituiu, portanto, uma reorientação fundamental, vista por muitos, como Leibniz, por exemplo, como um retorno às ‘qualidades ocultas’ da Escolástica”.

No entanto, para Newton, a concepção de um espaço absoluto era condição para assegurar a presença de Deus, como espírito extenso no mundo e, é por seu intermédio que se manifesta toda a atividade da natureza, inclusive através da possibilidade de variar as leis da Natureza e fazer diferentes mundos em várias partes do Universo, o que retira qualquer fundamento para um princípio de uniformidade da natureza. ${ }^{113}$

Newton afirma que a estrutura real do mundo é o resultado de uma escolha inteligente. O Deus de Newton não é meramente um Deus "fillosófico", como a desinteressada Causa Primeira dos aristotélicos ou o indiferente e ausente do mundo, o de Descartes. Ele é o Deus Bíblico, o Senhor efetivo do mundo por Ele criado, ele é a fonte das leis da Natureza. ${ }^{114}$

No entanto, Leibniz propôs uma espécie de harmonia pré-estabelecida entre a natureza e a graça divina, numa síntese da filosofia denominada de Monadologia. ${ }^{115}$ A mesma força e vigor subsistem sempre no mundo e "apenas passa de uma parte da matéria para outra, conformemente às leis da Natureza e à magnífica ordem preestabelecida" (KOYRÉ, 2006, p. 209). Para Leibniz, o mundo é um relógio que não precisa de reparo, uma vez que, antes de criá-lo, Deus previu tudo. O seu Deus não é o Deus newtoniano, ele é o Deus Bíblico do Sabá, que terminou sua obra e que vê que ela representa o melhor dos mundos possíveis. ${ }^{116}$ Resumindo esta ideia, no prefácio à obra de Leibniz "Protogaea”, “o mundo real é escolhido por Deus entre todos os mundos possíveis" (1997, p. 24).

À luz dessa metafísica, a história do universo é o desdobramento de possibilidades contidas em seu início, como em um embrião. Além disso, na origem dessa história não está o caos, mas os livres desígnios de Deus ou as leis de ordem geral do universo possível. Essa história realiza-se mediante "desordens" que são apenas aparentes, configurando-se como tais, aos nossos olhos humanos pelo fato de sermos incapazes da visão completa. ${ }^{117}$ Já que Deus implica o seu próprio ser e o das coisas, dever-se-á falar das próprias coisas, os objetos do mundo físico.

\footnotetext{
113 ABRANTES, "Imagens de natureza e de ciência", 1998, p. 84.

${ }^{114}$ KOYRÉ, "Do Mundo Fechado ao Universo Infinito", 2006, p. 199.

115 LEIBNIZ, "Protogaea", prefácio dos tradutores, 1997, p. 09.

${ }^{116}$ KOYRÉ, "Do Mundo Fechado ao Universo Infinito", 2006, p. 212-213.

${ }^{117}$ LEIBNIZ, "Protogaea", prefácio dos tradutores, 1997, p. 23-24.
} 


\section{II- As ideias de Natureza presentes na Literatura, sobretudo nas obras de Tratadistas Antigos e Medievais e seus influxos na Idade Moderna}

As ideias filosóficas dos antigos chegarão aos séculos medievais e à Idade Moderna também por meio da Literatura. Os grandes poetas do mundo greco-latino serão novamente, no século XVI, profundamente lidos.

A concepção de "natureza" que tais obras poéticas deixam entrever provém de embates principalmente entre o idealismo platônico e o materialismo de Epicuro. A obra “De natura rerum” de Lucrécio, discípulo de Epicuro, segundo Lenoble (1969, p. 103) darlhe a forma que reterá até o início da Idade Moderna.

A importância da poesia de Lucrécio é provada pela influência que exerceu sobre a poética dos seus sucessores, como Virgílio (71-19 a.C.) e Ovídio (43 a.C. - 17 d.C.), marcado, sobretudo, pelo entusiasmo pelo estudo da natureza. ${ }^{118}$

Virgílio escreveu as obras: "Geórgicas", a "Eneida" e as "Bucólicas”, que são uma coletânea formada por dez poemas pastoris, que relatam os cantos dos pastores, cujas éclogas se tornaram comuns para designar não apenas a obra virgiliana como todo o gênero pastoril na tradição Ocidental. Como gênero, uma bucólica é um poema que tem por cenário o campo e por personagens habituais pastores-cantores, numa paisagem amena, um lugar aprazível, muitas vezes à sombra de uma árvore. Os poetas cantam seus amores e se desafiam na contenda poética. É assim que eles se entregam às musas, numa posição espacial simbólica.

A obra "Bucólicas" cria, no imaginário ocidental, um espaço ideal, a Arcádia" ${ }^{119}$, que se torna, em Virgílio, um espaço vago, não localizável em uma só parte do mundo, um universo próprio que tenta se resguardar das duras realidades do exterior, povoada por pastores que celebram seus amores, cercados pela natureza. Além disso, paira sobre esse mundo à parte a perturbação infelicitadora da paixão amorosa, a natureza é acolhedora e confidente, mas incapaz de sanar certas feridas de amor. Um espaço de sonho onde às divindades gregas se mesclam divindades latinas. ${ }^{120} \mathrm{O}$ Éden bíblico voltado para o passado

\footnotetext{
118 LUCRÉCIO, “Da Natureza”, 1973, p. 38.

119 Arcádia é uma região grega, berço da poesia pastoril que, em Virgílio, transforma-se numa espécie de lugar ideal, não situável na geografia concreta, para abrigar o canto dos poetas-cantores bucólicos.

${ }^{120}$ VIRGÍLIO, "Bucólicas”, 1973, p. 12-13.
} 
em Ovídio, será deslocado para o futuro por Virgílio. Na Égloga I, Virgílio se expressa através de Melibeu:

Tu, sob a larga faia reclinado, Silvestre musa em tênue cana entoas: Nós, Títiro, da pátria os fins deixamos E a doce lavra, a pátria nós fugimos; As selvas tu, pausado à sombra, ensinas Amarílis formosa a ressoarem (1973, p. 29).

Neste trecho o pastor canta o nome da amada, Amarílis, que é ecoado por entre os bosques. Há, aqui, a personificação da natureza, que parece confraternizar com o pastorcantor, numa sinfonia harmoniosa. ${ }^{121} \mathrm{E}$, na Égloga IV, Virgílio postula que os vestígios da perversidade humana levarão o homem de novo a afrontar os mares, atitude que, no mito, é sentida como uma impiedade. Com efeito, "os mares separam as terras por obra dos deuses e vencer tais barreiras naturais é cometer sacrilégio", frase trazida por Odorico Mendes em nota à obra "Bucólicas" (1973, p. 89), que muito se assemelha à passagem de "O Uraguai" de Basílio da Gama, em que elementos naturais e morais se mesclam:

Gentes de Europa, nunca vos trouxera O mar, e o vento a nós. Ah! não debalde Estendeu entre nós a natureza Todo esse plano espaço imenso de águas (1996, p. 210).

Ao fechar suas notas às Bucólicas (1973, p. 192-193), Odorico Mendes se refere ao Brasil, cujos habitantes tinham certa cor pastoril, a ponto de representarem as mais salientes personagens da Antiguidade. Os naturais do Brasil formam três consideráveis divisões: os mais civilizados, cuja máxima parte se estende pelo litoral, com usos quase europeus, os selvagens e os sertanejos, em geral pastores. Quem descrever os mais civilizados, descreve os da Europa; os selvagens, de costumes quase homéricos, podem prestar-se a uma epopeia; e nossos Basílio e Durão, deles tiraram “O Uraguai” e o "Caramuru”. Quanto a divisão dos sertanejos, nunca foi cantada senão por eles próprios.

Outro tratadista da natureza foi Ovídio que escreveu a obra "Metamorfoses", coleção de lendas, derivada de associações mitológicas, a maioria de origem helênica, que

${ }^{121}$ MENDES apud VIRGÍLIO, “Bucólicas”, 1973, p. 41. 
relata a criação do mundo. Ovídio dotou os personagens divinos de emoções humanas e matizou as diferentes cenas com descrições da natureza, narrando a mudança da forma dos homens em animais, plantas e minerais desde a origem mitológica do mundo até o tempo do poeta, articulando-se em torno de fábulas que registram uma transformação que exerceu grande influência na poesia bucólica do Renascimento. ${ }^{122}$

Logo no proêmio das Metamorfoses, Ovídio inicia o argumento da criação do mundo, em que Caos reparte-se nos elementos zonas, ventos e criação do homem:

Antes do mar, da Terra e do céu que os cobre Não tinha mais que um rosto a Natureza:

Este era o Caos, massa indigesta, rude, E consistente só num peso inerte.

Das coisas não bem juntas as discordes, Priscas sementes em montão jaziam; O Sol não dava claridade ao mundo, [...] Não pendias, ó Terra, dentre os ares, $\mathrm{Na}$ gravidade tua equilibrada [...] Ar, pélago e Terra estavam mistos: As águas eram inavegáveis, Os ares negros, movediça a Terra.

Forma nenhuma em nenhum corpo havia, Que em cada qual dos embriões enormes Pugnavam frio, e quente, úmido, e seco, Mole, e duro, o que é leve, e o que é pesado.

Um Deus, outra mais alta Natureza À contínua discórdia enfim põe termo: A Terra extrai dos Céus, o mar da Terra, E ao ar fluido, e raro abstrai o espesso. [...] Súbito ao cume do convexo espaço $\mathrm{O}$ fogo se remonta ardente, e leve;

[...] Assim, depois que o Deus O grão corpo dispôs, quis dividi-lo, E membros lhe ordenou. Para que a Terra Não fosse desigual em parte alguma, Por todas a compôs na forma de orbe. Ao mar então mandou que se esparzisse, Que ao sopro inchasse dos forçosos ventos, E orgulhoso abrangesse as louras praias; Á mole orbicular deu fontes, lagos Rios cingindo com oblíquas margens... (2003, p. 15-16).

${ }^{122}$ OVÍDIO, "Metamorfoses", 2003, p. 12. 
Logo que tudo com limites certos

Foi pela eterna destra sinalado,

As estrelas que opressas, que abafadas

Houve em si longamente a massa escura,

A arder por todo o céu principiaram;

E porque não ficasse do universo

Alguma região desabitada,

Astros, e deuses têm o etéreo assento,

O mar aos peixes nítidos é dado,

Aves ao ar, quadrúpedes à Terra (2003, p. 18).

A estes animais faltava um ente

Dotado de mais alta inteligência,

Ente, que a todos legislar pudesse:

Eis o homem nasce, e - ou tu, suprema Origem

De melhor Natureza, e quanto há nela,

Ou tu, pasmoso Artífice, o formaste

Pura extração de divinal semente,

Ou a Terra ainda nova, inda de fresco

Separada dos céus, lhe tinha o germe.

[...], porém ao homem

O Fator conferiu sublime rosto,

Erguido para o céu lhe deu que olhasse (2003, p. 18).

Após a abertura do poema Ovídio descreverá as quatro idades do mundo. O dilúvio converte tudo em água e as pedras mudam-se em gente,

A Terra, pois, tão rude e informe dantes, Presenteou finalmente assim mudada, As humanas, incógnitas figuras.

Foi a primeira idade a idade de ouro: [...] O ferro sulcador não a rompia, E dava tudo à voluntária terra.

Depois que foi Saturno exterminado Ao Tártaro, e ficou a Jove o mundo, Veio outra idade, se inferior à de ouro, Sup'rior à de cobre, a idade argêntea. Jove contrai a primavera antiga, Verões, invernos, desiguais outonos, Curta e branda estação, que anime as flores. $\mathrm{O}$ ano repartem, variando os tempos. [...] Pela primeira vez o grão de Ceres Se esparziu, se escondeu nos longos sulcos, E oprimidos do jugo os bois gemeram. 
Às duas sucedeste, ênea prole,

De gênio mais feroz, mais pronto à guerra,

Mas não ímpio. - Eis a última, a de ferro,

Todo o horror, todo o mal rebentam dela (2003, p. 18-20).

Deste modo, após Ovídio elogiar o tempo ideal, em que a terra mesmo sem ser cultivada, dava frutos e colheitas, a raça humana passa a se degenerar, o que literalmente corresponde ao "atual" estado da humanidade. Esta teoria da degenerescência, liga-se a de um envelhecimento do mundo, que é admitida tanto por Lucrécio, que fala da terra esgotada, quanto por Sêneca, ao prever o cataclismo final, que será seguido de um novo período do mundo no qual as mesmas idades da humanidade se reproduzirão. ${ }^{123}$

Segundo Sérgio Buarque de Holanda, em sua obra "Visão do Paraíso", não carecia o mundo greco-romano da lembrança cultivada, de um estado de delícias que teria a humanidade vivido, no começo dos tempos, na infância do mundo, e que alguma terrível catástrofe viera a frustrar, deste modo, era natural que a situassem no passado, e representa o reverso necessário das misérias do presente; se não, leia-se o quadro da Idade de Ouro que se ostenta no pórtico das Metamorfoses. Aqui:

[...] a descrição daquele estado inaugural do homem e do cosmos traduz-se primeiramente no desaparecimento do intruso, que pretendendo administrar uma justiça exemplar e cruel, viria simplesmente transgredir as regras do jogo num universo lúdico por excelência, feito de tranqüila e ociosa irresponsabilidade. [...] A terra, bem comum de todos, produz continuamente, ainda ignorante da enxada e do arado que lhe ulcerassem a crosta, livre de cuidados ou solicitações, o fruto saboroso e a espiga loura e nutritiva. [...] Eterna é a primavera: um zéfiro amável abranda o ar e acaricia as flores que ninguém cultivou (HOLANDA, 1996, p. 151).

Também, conforme Sérgio Buarque Holanda, ainda que nessa cosmogonia a abolição da paisagem idílica e venturosa não se prenda ao erro do primeiro homem, mas à queda de Saturno, precipitado nas sombras do Tártaro por seu filho, nada de fundamental a separa do Éden bíblico. E como, em um e outro caso, o paraíso perdido fosse fabricado para responder a desejos e frustrações dos homens, não é de admirar se ele aparecesse, em vez de realidade morta, como um ideal eterno e, naturalmente, uma remota esperança. ${ }^{124}$

\footnotetext{
${ }^{123}$ HADOT, “O véu de Ísis”, 2004, p. 164.

${ }^{124}$ HOLANDA, "Visão do Paraíso", 1996, p. 151.
} 
Virgílio e Ovídio terão forte influência sobre os séculos vindouros e sobre os cronistas e viajantes do Brasil dos séculos XVI, XVII e XVIII. Outras importantes fontes de informações e de modelos epistemológicos que chegaram a Idade Moderna foram às obras dos naturalistas, isto é, dos autores de Tratados sobre a história natural.

Um tratadista de História Natural, que escreveu respeitável obra foi Estrabão (64-2 a.C. a 23 d.C.). Em sua "Geografia", ele mesmo se intitula filósofo estóico, ainda que seus primeiros mestres fossem peripatéticos. Das ideias estoicas provém sua fé firme nas obras da natureza e no papel da providência, que engendra os seres vivos. ${ }^{125}$

A investigação de Estrabão abarca relatos de viagens terrestres e marítimas com fins práticos, em que a exploração está a serviço da expansão política e do intercâmbio comercial. Com frequência seus escritos se limitavam a um catálogo de acidentes naturais, fazendo menção aos lugares habitados e aos diferentes povos, além de um esboço dos principais recursos econômicos.

Segundo Estrabão, o clima das regiões demasiado ao norte e demasiado ao sul torna difícil a vida civilizada e, dentro da zona temperada, o clima europeu é melhor devido à mescla que obriga a trabalhar, frente ao asiático que faz a vida demasiado fácil; mas o caráter particular de cada raça depende em grande medida do azar, não da providência e nele cooperam a natureza e o costume humano. Também, o Tratado de Hipócrátes "Dos ares, águas e lugares”, trouxe importantes avanços sobre o influxo do clima na saúde dos povos e será de uso corrente em toda a Antiguidade. ${ }^{126}$

Em Estrabão, há um equilíbrio instável entre a natureza e o homem, que pode romper-se a qualquer momento, visto que uma natureza difícil em regiões de climas extremos, seja pelos frios excessivos do norte ou pela seca da zona tropical, é um freio para uma vida plenamente civilizada. No entanto, boas condições naturais favorecem o progresso, mas não o garantem. Só os povos capazes de organizar-se social e politicamente conseguem aproveitar a ocasião. E uma natureza pródiga pode ser um obstáculo porque os homens tendem a cair na moleza e podem perder o bem-estar alcançado. A teoria de Estrabão tem um ar aristotélico, visto que a melhor civilização é um termo médio entre uma

\footnotetext{
${ }^{125}$ BLANCO, "Introdução", in: ESTRABÃO, “Geografia”, 1991, p. 46.

${ }^{126}$ ESTRABÃO, “Geografia”, 1991, p. 60-70 e p. 144.
} 
natureza demasiado pobre ou demasiado rica e entre uns povos que devem trabalhar em excesso, e outros que, com mínimo esforço, receberiam o máximo fruto da natureza. ${ }^{127}$

Contemporâneo de Estrabão é o naturalista Plínio, o Velho (23-79 d.C.) que vive num decadente mundo antigo. Sua obra "dominará os Bestiários da Idade Média; os escultores das catedrais representarão as plantas e os animais que ela descreve e construirão em parte o seu simbolismo a partir das propriedades" (1969, p.120) que terão aprendido na sua "História Natural". Ele se utiliza de um panteísmo sincrético, originário de correntes estoicas e platônicas, que permite um amplo recurso à finalidade de redescobrir a Natureza.

Plínio professa uma respeitosa humildade ante a Natureza, que é o mundo, que é Deus, numa evidente fundamentação estoica, resumindo os conhecimentos botânicos e meteorológicos de seu tempo. Ele quis eliminar todos os fantasmas de uma imaginação popular alimentada de magia oriental. Ainda que Deus seja igual à Natureza, a ideia de um Deus providente é útil numa perspectiva de ética social. ${ }^{128}$

No livro II da "História Natural", Plínio trata das concepções físicas do mundo, que correspondem à distinção dos quatro elementos fundamentais: fogo, ar, terra e água ${ }^{129}$, sendo que o mais elevado é o fogo; o seguinte, o ar, elemento vital que se infiltra e se mescla no conjunto das coisas. Graças à sua energia, a terra se sustenta em posição central, estando contrabalançada pelo quarto elemento, a água. ${ }^{130}$

A esfera que "encerra" o mundo obriga este todo a manter-se no lugar, sendo que a terra é o eixo do mundo, mantendo em equilíbrio o que a mantêm em suspenso. Neste sentido, o imobilismo da terra é a consequência de um sistema equilibrado de todo o Cosmos. Um século depois, esta astronomia vai encontrar-se cristalizada no Almagesto. ${ }^{131}$ O mundo que em cujo seio transcorre todas as coisas, á que crer que é igual à divindade, eterno e que não tem sido engendrado nem jamais perecerá, ${ }^{132}$ é sagrado, não só é a própria obra da natureza física, senão também a mesma natureza física. ${ }^{133}$

\footnotetext{
${ }^{127}$ ESTRABÃO, “Geografia”, 1991, p. 149-150.

${ }^{128}$ SERBAT, "Introdução", in: PLÍNIO, "História Natural”, 1995, p. 8-9.

${ }^{129}$ PLÍNIO, "História Natural", 1995, p. 71.

${ }^{130}$ Ibidem, p. 337-341.

${ }^{131}$ LENOBLE. "História da ideia de Natureza", 1969, p. 122-123.

132 BEAUJEU, em comentário a edição do Livro II de Plínio resume assim os usos dos termos: "céu" significa a esfera donde estão as estrelas; e o espaço intermédio de onde se movem os planetas; "mundo" tem o sentido do "conjunto do universo" (gr. kósmos). Apud, PLÍNIO, "História Natural", 1995, p. 337.

${ }^{133}$ Tal é o significado dos termos kósmos, em grego, e mundus, em latim.
} 
A definição de Natureza recebida dos Gregos, o natural como ordem independente das coisas humanas, aplicou-a Plínio a uma afetividade muito mais primitiva, em que

[...] a Natureza é construída como um conjunto de qualidades exteriorizadas: o quente e o frio, o pesado e o leve, etc.; a doutrina dos 'lugares naturais' exporta para as coisas a nossa apreciação do alto e do baixo e também os múltiplos valores mágicos ligados à orientação; finalmente, a ação causal permanece estreitamente concebida segundo analogias biológicas e artificialistas, como na teoria aristotélica das quatro causas ou na doutrina da simpatia e da antipatia (LENOBLE, 1969, p. 160).

A analogia da simpatia e antipatia impõe-se a um fato, os fenômenos não se produzem ao acaso, mas agrupados em conjuntos, permanecendo encoberta a sua lei, todos estes fenômenos estão ocultos na majestosa natureza. ${ }^{134}$ Deste modo, "há uma fauna e uma flora 'quentes', uma fauna e uma flora 'frias"' (LENOBLE, 1969, p. 162), mas, uma vez compreendidas, causarão sérios problemas, pois essa compreensão não reúne fenômenos comprovados, mas naturezas, numa verdadeira fisiomaquia, como na ação por simples contato, em que grande número de animais, sobretudo os venenosos matam pela simples presença ou pelo simples olhar. ${ }^{135}$ Esse tipo de compreensão por analogia psicológica também será encontrado no período renascentista, que influenciará os cronistas e viajantes portugueses na compreensão da fauna e flora do Novo Mundo.

Ao realizar uma análise da obra "Geografia", na história do pensamento ocidental, Lenoble nos apresenta sua reflexão sobre a importância do Tratadista, ao afirmar que Plínio deu à Natureza um rosto que ela vai manter durante mais de quinze séculos. Ele descreve o céu, as plantas e os animais: “salve, mãe de todas as coisas, ó Natureza". 136

\footnotetext{
${ }^{134}$ PLÍNIO, "História Natural”, 1995, p. 385.

135 LENOBLE, "História da ideia de Natureza", 1969, p. 162.

${ }^{136}$ Ibidem, 1969, p. 119.
} 


\section{III - As Representações da natureza brasileira}

\section{1 - A posição geográfica e os aspectos astronômicos}

Antes mesmo de estabelecer qualquer análise a respeito da posição geográfica é importante não nos esquecermos de que a delimitação das "terras brasileiras", a ocidente, mesmo que sem o efetivo conhecimento do que havia até o limite destas terras, já havia sido estabelecida a priori pelo Tratado de Tordesilhas de 1494, através do marco de 370 léguas a oeste da ilha de Santo Antão em Cabo Verde.

No entanto, se o limite territorial a ocidente já fora traçado, o reconhecimento das terras descobertas se efetivara no início do século XVI a partir do oriente por integrantes da esquadra de Cabral, conforme lemos nos relatos de Pero Vaz de Caminha, de João Faras e do Piloto Anônimo ${ }^{137}$, a partir do dia 22 de abril de 1500, em que avistaram o monte Pascoal. Ao ancorarem nestas novas terras, Bartolomeu Dias, Nicolau Coelho e Pero Vaz de Caminha foram à praia, em Porto Seguro, e puderam conhecer, ainda que superficialmente, os primeiros locais da costa brasileira.

É importante constatar que, logo após o descobrimento, em 1502, o Brasil teve o seu território representado no planisfério do cartógrafo lusitano Alberto Cantino, que é a primeira carta geográfica a localizar o território brasileiro, ainda que sem exatidão fronteiriça ao norte, ao sul e a oeste.

A nova terra recebeu algumas denominações, como de Vera Cruz pelo Mestre João Faras; Ilha de Vera Cruz por Pero Vaz de Caminha; Terra de Vera Cruz por Pedro Álvares Cabral; e foi descrita pelo Piloto Anônimo como "Terra dos papagaios". Entretanto, não teve nenhum desses nomes aprovados por D. Manuel, uma vez que, na carta de 1501, os reis católicos, Fernando e Isabel a tratam por Terra de Santa Cruz.

A nova descoberta acabou por atrair negociantes interessados no pau-brasil, preciosa madeira cor de brasa. Isso foi suficiente para que a terra descoberta mudasse de nome, ainda na primeira década do século XVI, passando de Terra do Brasil para Brasil. Assim, o nome nascido na lenda cartográfica medieval, confirmado pelos textos de Caminha e Vespúcio, que a davam como terra adâmica, fecha um ciclo na procura do

\footnotetext{
${ }^{137}$ PEREIRA, "Os três únicos testemunhos do Descobrimento do Brasil", 1999, p. 73. In notas: O historiador norte-americano William Brooks Greenlee pesquisou a identidade do autor desta Relação e chegou à conclusão de que o seu autor era o escrivão da nau Capitânia, João de Sá.
} 
Éden. ${ }^{138}$ Segundo Paulo Roberto Pereira "aquele encontro num porto seguro, [...] com todos os indícios de um Éden ainda não violado, justifica a cena amistosa do encontro entre mundos diferentes que a mão do destino viera entrelaçar para a posteridade" (1999, p. 66).

Em Portugal, a notícia do descobrimento do Brasil foi mencionada pelo grande poeta na segunda metade do século XVI, como "a Terra Santa Cruz pouco sabida", conforme a chamou Luís Vaz de Camões nos tercetos que antecedem à "História da Província Santa Cruz", de Pero de Magalhães Gandavo, que é o primeiro livro português dedicado exclusivamente ao Brasil, impresso em 1576. ${ }^{139}$

No primeiro capítulo da "História da Província de Santa Cruz" que trata de como se descobriu esta Província e a razão por que se deve chamar Santa Cruz e não Brasil, Gandavo escreve que Pedro Álvares Cabral chegou a um porto limpo onde entraram e o denominaram Porto Seguro, por lhes acolher da tempestade..$^{140}$ A partir desse momento, muitos navios vieram às tais terras, e assim, progressivamente o território foi sendo descoberto e povoado pelos portugueses, assim descrito por Gandavo:

Esta provincia Santa Cruz està situada naquella grande America, uma das quatro partes do mundo. Dista o seu principio dous graos da equinocial para a banda do Sul, e dahi vai estendendo para o mesmo sul atè quarenta e cinco graos. De maneira que parte della fica situada debaixo da Zona torrida e parte debaixo da temperada. Està formada esta Provincia á maneira de huma harpa, cuja costa pela banda do Norte corre do Oriente ao Ocidente e está olhando direitamente a Equinocial; e pela do Sul confina com outras Provincias da mesma America povoadas e possuidas de povo gentilico, com que ainda nam temos communicaçam. E pela do Oriente confina com o mar Oceano Africo. E pela do Occidente confina com as altissimas serras dos Andes e fraldas do Perú; as quaes sam tam soberbas ensima da terra que se diz terem as aves trabalho em as passar (1980, p. 81).

Ambrósio Fernandes Brandão nos "Diálogos das Grandezas do Brasil", através do interlocutor Brandônio nos relata que, "desde o Pará ou rio das Amazonas, que está situado na linha equinocial, até a capitania de São Vicente" (1943, p. 77), há bastante terra para se poder situar nela grandes reinos e impérios. O que mais espanta é ver que toda esta grandeza da costa, tanto no sertão, como no litoral, "tem excelentíssimo céu e goza de

\footnotetext{
${ }^{138}$ FONTANA, “O Brasil de Américo Vespúcio”, 1995, p. 135.

${ }^{139}$ PEREIRA, "Os três únicos testemunhos do Descobrimento do Brasil”, 1999, p. 27-28.

${ }^{140}$ GANDAVO, "Tratado da Terra do Brasil - História da Província de Santa Cruz”, p. 78-80.
} 
muito bons ares, sadia e disposta para a conservação da natureza humana" (BRANDÃO, 1943, p. 77).

No entanto, Simão de Vasconcelos, na "Crônica da Companhia de Jesus", nos conta que, ao ser descoberto este Novo Mundo pelos portugueses, deve averiguar que a linha imaginária que foi traçada de norte a sul, a partir de 370 léguas a oeste de Cabo Verde, tivera "diversas arrumações" das cartas geográficas, que vieram a ocasionar variedades. Sendo assim, está de posse o Brasil da terra, que se estende pela costa desde o grão Rio das Amazonas até o da Prata. ${ }^{141}$

Logo que soaram, em Portugal, as primeiras notícias do descobrimento de terras tão espaçosas e regiões tão férteis, enviou Dom Manuel, a princípio, um grande cosmógrafo chamado Américo Vespúcio a reconhecer e demarcar a costa marítima deste Novo Mundo. Sem muito sucesso, logo após ele, a mando do rei, veio o capitão Gonçalo Coelho explorar mais detalhadamente a costa e, assim, descobriu uma diversidade de portos, rios e enseadas. Contudo, pela pouca notícia que se teve, mandou Martim Afonso de Sousa, que percorreu a costa desde a capitania de São Vicente até o Rio da Prata, descobrindo portos, rios, enseadas, pondo nomes, demarcando e investigando a qualidade das terras.

Diante destes relatos de Pero de Magalhães Gandavo, de Ambrósio Fernandes Brandão e de Simão de Vasconcelos, pudemos constatar que se os contornos do Brasil, ao norte, já estavam relativamente delimitados pelo portentoso rio Amazonas e a leste pelas salinas águas do Atlântico, pairavam dúvidas, ao sul, se o limite estava próximo a Cananeia ou se este marco se alongava até o rio da Prata. A oeste, o Tratado de Tordesilhas estabelecia seu limite, mas, no que se refere ao conhecimento territorial, nada estava definido pela experiência, devido à vastidão territorial, ao perigo do canibalismo e conflitos com indígenas e à dificuldade de acesso nos dois primeiros séculos da colonização.

Como a maioria dos autores analisados são jesuítas, torna-se fundamental averiguarmos onde foram instalados os principais colégios da Companhia de Jesus que acompanharam fundamentalmente o desenvolvimento geral da colonização, bem como os principais campos de atividade intelectual e cultural do Brasil Colônia, que se localizavam em Recife e Olinda, em Salvador da Bahia, em Ilhéus, em Porto Seguro, no Espírito Santo, no Rio de Janeiro, em São Vicente e em São Paulo de Piratininga.

${ }^{141}$ VASCONCELOS, “Crônica da Companhia de Jesus”, 1977, v. 1, p. 57. 
A Bahia é a principal capitania do Brasil, e segundo Simão de Vasconcelos, é como um grande gigante, sendo que ao norte se estendem as capitanias de Sergipe, Pernambuco, Itamaracá, Paraíba, Rio Grande, Ceará, Maranhão e Grão-Pará, e ao sul localizam-se as capitanias de Ilhéus, Porto Seguro, Espírito Santo, Rio de Janeiro e São Vicente até o Rio da Prata. O primeiro descobridor desta Bahia foi Cristóvão Jacques, que demarcando os portos desta costa e adentrando-a, por sua formosura, "lhe pôs o nome de Bahia de Todos os Santos; assim chamada, ou porque parece um paraíso, onde habitam todos os santos; ou porque parece que todos os santos do paraíso influem nela alguma parte de suas qualidades" (VASCONCELOS, 1977, v. 1 p. 187).

No princípio da catequese promovida pelos jesuítas, chegou ao Brasil, em 1549, com Tomé de Souza, o padre Manuel da Nóbrega para efetivar a conversão das almas gentílicas através da fundação dos colégios da Bahia, de São Vicente, do Espírito Santo, de Pernambuco e de Porto Seguro. Não nos esqueçamos de que a Companhia de Jesus nascera por confirmação de Bulas Apostólicas em 1540, sendo designado Inácio de Loyola, para catequizar as almas dos indígenas, em que as águas do oceano Atlântico o privaram do meio comum da fé, uma vez que Deus guardava este novo mundo, por segredos ocultos de sua providência, para que fosse descoberto somente neste tempo e, assim, para que obtivessem a salvação eterna. ${ }^{142}$ E, conforme pensamento de Santa Rita Durão o Brasil “infunde-me a confiança que ali renasça o português império" (2005, p. 210).

Quando o governador Tomé de Souza e o padre Nóbrega chegaram ao Brasil, viram os sinais da desejada terra, os claros ares, os ventos serenos, as águas de prata que arrebentavam os olhos, os montes altos, verdes e aprazíveis que enlevavam junto com a vista os corações dos navegantes. Todavia, o que mais admira e faz todo este recôncavo mais útil, é a providência exclusiva com que a natureza nos ofereceu portos e comércio a todas estas lavouras, que ao se juntar aos rios maiores uma grande quantidade de riachos encontrados por esta terra:

[...] com tão alegre confusão, que se não pode facilmente julgar, se está aqui a terra no mar, se o mar na terra. [...] As margens, e ribeiras dos rios por ordinário estão galanteadas da verdura dos mangues, mui engraçados, não só por verdes, mas por aquelas singulares laçadas, com que a natureza vigorosa os enredou (VASCONCELOS, 1977, v. 1, p. 188).

${ }^{142}$ VASCONCELOS, “Crônica da Companhia de Jesus”, 1977, v. 1, p. 169-170. 
Fernão Cardim, em missão jesuítica pela Bahia, Ilhéus, Porto Seguro, Pernambuco, Espírito Santo, Rio de Janeiro, São Vicente e São Paulo, desde o ano de 1583 ao de 1590, narra ao padre provincial de Portugal, Christovão Gouvêa, que a Bahia, por estar sobre o mar, é de vista aprazível para a terra e para o mar e sua terra é farta de mantimentos. ${ }^{143}$

No “Tratado Descritivo do Brasil”, Gabriel Soares descreve as qualidades existentes na Bahia e afirma que o rei D. João III de Portugal gostava tanto do Brasil, especialmente da Bahia, que se vivesse por mais alguns anos, edificaria nele um dos mais notáveis reinos e engrandeceria a cidade de Salvador, "porque esta baía é grande e de bons ares, mui delgados e sadios, de muito frescas e delgadas águas, e mui abastada de mantimentos naturais da terra, de muita caça, e muitos e mui saborosos pescados e frutas" $(1987$, p. 141).

A capitania de Pernambuco se localiza entre o Rio São Francisco e rio Igaruçu. Toda a terra é bem assentada, formada por montes e campinas, composta de solo fértil que propicia bons cultivos. Os campos são fecundos, com muitos rios caudalosos e navegáveis, abundantes de fontes e águas salutíferas. Seu arvoredo compete com as nuvens, constituído de perpétua verdura. Da bondade do clima, ares vitais e mais comodidades para a vida humana basta dizer que é parte principal do Brasil, conforme a descreveu Simão de Vasconcelos. ${ }^{144}$ Também nos faz uma bela descrição desta capitania Santa Rita Durão ao dizer que:

A oito graus do equinócio se dilata Pernambuco, província deliciosa, A pingue caça, a pesca, a fruta grata, A madeira entre as outras mais preciosa: O prospecto, que os olhos arrebata $\mathrm{Na}$ verdura das árvores frondosa, Faz que o erro se escuse a meu aviso De crer que fora um dia o Paraíso (2005, p. 204).

Bento Teixeira em sua obra "Prosopopeia", faz uma descrição do porto de Recife, localizado na capitania de Pernambuco, em que a natureza aparece representada como uma mãe prudente, conforme lemos na estrofe XVII:

\footnotetext{
${ }^{143}$ CARDIM, "Tratados da Terra e Gente do Brasil", 1980, p. 144.

${ }^{144}$ VASCONCELOS, “Crônica da Companhia de Jesus”, 1977, v. 1, p. 226.
} 
Era a parte do Sul,

onde a pequena, ${ }^{145}$

Ursa, se vé de guardas rodeada,

Onde o Ceo luminoso,

mais serena,

Tem sua influyção ${ }^{146}$, e temperada.

Iunto da noua Lusitania ordena,

A natureza, mãy bem atentada,

Hum porto tam quieto, \& tam seguro,

Que pera as curvas naos serve de muro (1969, p. 127).

A capitania do Espírito Santo foi fundada no ano de 1525 por Vasco Fernandes Coutinho, está situada em lugar que possibilita sua defesa, é cômoda para a vida humana, cercada de água, armada de penedia, horrível por natureza e habitável por arte, junto ao rio, perto da barra, contendo muita pesca e mariscos em grande quantidade. Seus arredores são de terra fértil e seus campos amenos, cortados por rios e fontes, suas matas exalam muitos cheiros deliciosos, bálsamos, copaíbas, almácegas e seus montes estão cheios de minas de muitas pedras, bem como de prata e ouro. ${ }^{147}$

Na capitania do Rio de Janeiro segundo Fernão Cardim, a cidade de mesmo nome está situada em um monte de boa vista para o mar e dentro da barra tem uma baía que bem parece que "a pintou o supremo pintor e arquiteto do mundo Deus Nosso Senhor" (1980, p. 170), e assim é a coisa mais formosa e aprazível que há em todo o Brasil, toda cheia de ilhas com grandes arvoredos, sendo muito sadia e contendo bons ares e águas,

No verão tem boas calmas algumas vezes, e no inverno mui bons frios; mas em geral é temperada. $\mathrm{O}$ inverno se parece com a primavera de Portugal: tem uns dias formosissimos tão aprazíveis e salutiferos que parece estão os corpos a beber vida. É terra muito fragosa [...] tudo são serrarias e rochedos espantosos, [...] destas serras descem muitos rios caudaes (CARDIM, 1980, p. 170).

Ambrósio Fernandes Brandão, em sua obra "Diálogos das Grandezas do Brasil", apresenta através do interlocutor Brandônio a capitania de São Vicente, que era a última povoada na costa do Brasil, e que aos poucos vai expandindo, principalmente a partir da

\footnotetext{
${ }^{145}$ TEYXEIRA, 1969, p. 127, in notas: Neste verso, fala o autor da "pequena Ursa", isto é, a menor estrela da constelação da Grande Ursa. Os astrônomos a chamam de Astor ou Cavaleiro. No Nordeste, o povo a designa por Carreiro. Supomos que esta designação coexista ao lado de outra, a de Úrsula, a qual estaria presente na mente do poeta. Há, em Caruaru (PE), uma "serra da Úrsula".

${ }^{146}$ Ibidem, p. 127, in notas: Palavra arcaizada, para designar, especialmente, a influência astral. A influyção "mais serena e temperada" era característica do hemisfério boreal.

${ }^{147}$ VASCONCELOS, “Crônica da Companhia de Jesus”, 1977, v. 1, p. 225.
} 
descoberta de ouro. Ele afirma ter visto grão de ouro, "tirado de suas minas, como a natureza o criou" (BRANDÃO, 1943, p. 76).

Simão de Vasconcelos, ao descrever a capitania de São Vicente, afirma ser esta uma das primeiras capitanias a terem sido instaladas e a primeira em que se fez açúcar, possuindo terras fecundas e abundante gado:

[...] a região é alegre, aprazível e saudável: tem a variedade de verão e inverno, fora do comum de toda a outra terra do Brasil dela para o Norte, com os mesmos frios e calmas, que experimentam na Europa, com mais rigor pela terra dentro: trocadas porém as sessões; porque o verão, são os seis meses do inverno e o inverno são os seis meses do verão do clima da Europa (que assim soube trocar as mãos o Autor da Natureza para os fins que pretendia). O terreno é fertilíssimo, não só dos frutos comuns do Brasil, mas dos frutos, frutas e flores melhores da Europa: especialmente se formoseia de abundantes searas de trigo e fecundas vinhas. Os campos recreiam os olhos, igualmente vestidos de erva, flores e gado em número excessivo, e de todos os gêneros. É a fartura de todo o estado de carnes e trigo, esta capitania: e pode dizer-se dela [...] que é o celeiro de todo o Brasil (1977, p. 206-207).

Em 1553, durante o governo de Duarte da Costa, Manuel da Nóbrega funda um colégio nos campos de Piratininga, que merece o nome de alísios ou de bem afortunados, devido a melhor natureza do mundo. Depois de atravessada toda aquela notável serrania, Simão de Vasconcelos era recompensado, porque ao sentar em um alto cume, "parecia que olhava do céu da lua, e que via todo o globo da terra posto debaixo de meus pés; e com notável formosura, pela variedade de vistas do mar, da terra, dos campos, dos bosques e serranias, tudo vário, e sobremaneira aprazível" (1977, v. 1, p. 252-253).

Esta segunda região do ar de que fala Simão de Vasconcelos, provém daquela antiga filosofia aristotélica, que envolve o mundo supralunar, consubstanciado pelo éter, a "quinta essência" localizada numa segunda região, e a dos quatro elementos corruptíveis do sistema de Empédocles que correspondem ao mundo supralunar que vigorou como se vê no imaginário de nossos cronistas.

Deste modo, a colonização portuguesa inicia-se com a instalação de enclaves, que atuam como bases de difusão do processo, que evoluem para regiões, que abrigam assentamentos e fluxos permanentes e consolidados. Tais conjuntos regionais acabam por conformar efetivos territórios do Brasil Colônia. 
Quanto aos aspectos astronômicos, Sérgio Buarque de Holanda afirma que nada prova, de modo decisivo, que, antes de 1480, fosse conhecida a navegação astronômica. Quando muito pode supor-se que essa possibilidade foi aventada por G. Beaujouan em suas viagens ao longo da costa africana, que, "os portugueses fariam desembarcar eventualmente algum astrônomo para determinar em terra a altura alcançada, ora - ao norte do Equador mediante a observação da estrela polar, ora - ao sul - pela altura do sol” (1960, p. 30).

Quem nos deu os primeiros testemunhos, especificamente do Atlântico sul, próximo ao litoral brasileiro durante a chegada da frota cabralina a Porto Seguro, em abril de 1500, foi o astrônomo João Faras, tradutor do manual de Geografia e Cosmografia, "De situ orbis", de Pompônio Mela, escritor latino do século I, numa época em que a Astronomia ainda se encontra associada à Astrologia.

João Faras, que fez parte do humanismo ibérico, foi quem realizou as primeiras observações astronômicas próximas ao território brasileiro. Escreveu uma carta em que se identificam as estrelas da constelação do Cruzeiro do Sul, dirigida ao rei D. Manuel, e que consta como o único texto escrito na semana em que a frota ficou ancorada na Baía Cabrália que contém um esboço descritivo das estrelas do céu, visto a partir de terras brasileiras, assim narrado por ele:

[...] estas Guardas nunca se escondem, antes sempre andam ao derredor sobre o horizonte, e ainda estou em dúvida que não sei qual de aquelas duas mais baixas seja o pólo antártico; e estas estrelas, principalmente as da Cruz, são grandes quase como as do Carro; e a estrela do pólo antártico, ou Sul, é pequena como a do Norte e muito clara, e a estrela que está em cima de toda a Cruz é muito pequena (Apud PEREIRA, 1999, p. 70). ${ }^{148}$

Pretendia-se negar até o próprio céu, comum às criaturas todas, que em toda a zona tórrida não havia céu correspondente, porque afirmavam os antigos filósofos e astrólogos que não era esférico. Notadamente Procópio afirmava que é contra a Sagrada Escritura a sentença de Aristóteles, de ser o céu esférico e se mover ao redor da terra. Por esta via pretendiam diversos doutores aniquilar a terra do Brasil e de toda a América. Simão de

\footnotetext{
${ }^{148}$ PEREIRA, 1999, p. 70, in notas: guardas são as estrelas Alfa e Gama da constelação do Cruzeiro do Sul, cujo alinhamento fornece a direção do polo celeste; Cruz é a identificação da constelação austral formada pelas estrelas Alfa, Beta, Gama, Delta Crucis e Epsilon Crucis, denominada pela primeira vez de Cruz por João Faras; Carro: nome pelo qual também é conhecida a constelação da Ursa Maior, sobretudo por causa das sete estrelas que formam o Carro ou a Grande Carroça já representada pelos romanos.
} 
Vasconcelos se perguntava por que razões criaria o Autor da natureza terra que não havia de ser habitada, pela inclemência dos astros, quando nela admitíssemos Céu. Autores sapientíssimos como Tales, Pitágoras, Aristóteles, Ptolomeu e Platão provam, para Simão de Vasconcelos, com razões evidentes que à toda a terra corresponde o céu, por ser esférico. Através da experiência do movimento do sol, da lua e das estrelas, as vemos passar todos os dias do horizonte oriental ao ocidental. Da mesma forma vai o céu rodeando a terra com suas estrelas fixas igualmente distantes, conforme o Eclesiastes, na Sagrada Escritura, que diz que o sol põe-se e torna a seu lugar. ${ }^{149}$

No entanto, Simão de Vasconcelos, em sua obra "Crônica da Companhia de Jesus", ironiza os antigos filósofos, por anunciarem interpretação tão descabida referente à inexistência de céu nesta terra brasílica, ao nos relatar que a Bahia

[...] está em altura de treze graus e meio, entre a linha, e trópico Austral; e, contudo zombam seus naturais da doutrina dos antigos filósofos, que tinham para si que era inabitável esta parte do mundo, que não tinha Céu, que carecia de antípodas, e outros sonhos contrários do que hoje nos mostra a experiência. Faltava só que fosse também melhor o Céu desta parte; e não será temeridade afirmá-lo; segundo a doutrina que temos assentado no livro segundo das Curiosidades do Brasil. Parece na verdade se pôs a natureza a formar esta parte do mundo, quando estava com a mão mais folgada; como lá disse Plínio na sua Campanha (1977, v. 1, p. 190).

Segundo Robert Lenoble (1969), Plínio afirma que "o mundo tem a forma de um globo perfeito", sendo que o interior desta esfera encerra os quatro elementos que compõem todas as coisas. A esfera que "encerra" o mundo obriga este todo a manter-se no lugar, e acrescenta que "nesta revolução eterna do universo, a terra é o eixo do mundo, mantendo em equilíbrio o que a mantém em suspenso. Desta forma, só ela está imóvel, enquanto tudo se move em redor dela". Neste sentido, o imobilismo da terra é a consequência de um sistema equilibrado de todo o Cosmos. ${ }^{150}$ Também para Estrabão, o universo e o céu são esféricos, uma vez que os astros giram em torno do centro, sendo que nesse centro se encontra a terra imóvel, ao redor da qual gira o céu. ${ }^{151}$

Para Simão de Vasconcelos, os astros que predominam nesta região do Brasil, conhecidamente são bons e se não excedem, nada ficam aquém às mais partes do mundo.

\footnotetext{
149 VASCONCELOS, “Crônica da Companhia de Jesus”, 1977, v. 1, p. 138-140.

${ }^{150}$ LENOBLE, "História da ideia de Natureza”, 1969, p. 122-123.

${ }^{151}$ ESTRABÃO, “Geografia”, 1991, p. 110.
} 
Porque nesta terra a formosura, candura, pureza e resplendor do sol, lua e estrelas parece estar no mesmo ponto de sua primeira criação. Podemos ver através da formosura e claridade das estrelas, "que é bem conhecida a de um Cruzeiro, que são as quatro estrelas puras postas em Cruz, e uma mais que lhe forma o pé, princesa destes céus, ornato das estrelas Antárticas e guia segura dos navegantes" (1977, v. 1, p. 159). As notícias da terra dadas pelos capitães e cosmógrafos, davam conta de que:

[...] não viram cousa igual no universo todo à perspectiva desta nova terra, porque ao longe, parece uma glória o avultar dos montes e serranias, com tal compostura e altura, que representam formas muito para ver, e sobem, parece, à região segunda do ar, levando consigo os olhos e os corações ao Céu. À meia vista, começa a aparecer o alegre dos bosques, campos, e arvoredos, verdes sempre, e sempre aprazíveis. Mais ao perto, alvejam-se as praias formosas e vão logo aparecendo nelas uma imensidade de portos, barras, enseadas, rios, ribeiras despenhadas, e com tão grande variedade, que é um espanto da natureza (VASCONCELOS, 1977, v. 1, p. 60).

Torna-se importante precisar que esta descrição feita por Simão de Vasconcelos, ao se referir à "segunda região do ar", quando via as nuvens na serra do mar a caminho de São Paulo, está em consonância com a visão aristotélica de que o conjunto da natureza estaria dividido na região sublunar, em que cada um dos elementos teria seu "lugar natural" e na região supralunar, constituída por uma quinta essência. E assim fica certificada a existência de um céu visto de qualquer parte da Terra, inclusive do Brasil. 


\section{2 - Os climas}

De uma maneira geral, aparecem frequentemente nos escritos dos cronistas e viajantes inúmeras referências que tratam da benignidade dos climas, dos seus bons ares, da propriedade medicinal dos ventos e de suas amenidades, por não possuírem nem calor nem frio excessivo.

Segundo Sérgio Buarque de Holanda, na obra "Etimologias" de Isidoro de Sevilha, encontramos os mesmos ingredientes utilizados pelo poeta Prudêncio na sua descrição do Paraíso. Nesse horto de delícias predomina a perene primavera, pois não se conhece ali nem frio nem calor, mas uma constante temperança do ar. A influência duradoura de Isidoro sobre teólogos e eruditos há de transformar-se em patrimônio comum a toda Idade Média. A mesma paisagem agradável, a mesma eterna primavera que os descobridores renascentistas irão buscar nas terras desconhecidas do outro lado do Oceano já tinham comovido os primeiros autores medievais. ${ }^{152}$

Esta ideia, que percorre toda a Idade Média participará também dos relatos dos Cronistas e Viajantes portugueses, como podemos averiguar na "Carta" de Caminha, em que neste Brasil a "atrra em sy he de mujto boos aares asy frios e tenperados" (1968, p. 56). E Gandavo, em sua obra "História da Província de Santa Cruz", nos relata que:

[...] he esta Provincia sem contradição a melhor pera a vida do homem que cada huma das outras de América, por ser commummente de bons ares e fertilissima, e em gram maneira deleitosa e aprazivel á vista humana. O ser ella tam salutifera e livre de enfermidades, procede dos ventos que geralmente cursão nella: os quaes são Nordestes e Sues, e algumas vezes Lestes e Lessuestes. E como todos estes procedão da parte do mar, vem tam puros e coados, que nam somente nam dânam; mas recream e acrescentam a vida do homem (1980, p. 81).

Em sua obra "Tratado da Terra do Brasil”, Gandavo também afirma haver nestas partes do Brasil, seis meses de verão e seis de inverno, e os dias quase sempre são iguais às noites. Esta terra é sempre quente, quase a mesma coisa no inverno e no verão. A viração do vento geral que chega em torno do meio dia, é tão fresca e fria que não se sente mais

\footnotetext{
${ }^{152}$ HOLANDA, "Visão do Paraíso", 1996, p. 169.
} 
calor, e ficam recreados os corpos das pessoas. ${ }^{153}$ Provavelmente ele se refere à região que vai da Bahia para o sul do Brasil, visto que não chegou a conhecer as capitanias ao norte.

Ambrósio Fernandes Brandão, no segundo diálogo de sua obra nos explica, através do interlocutor Brandônio, que a amenidade do clima se deve aos "ventos da Guiné", que são ventos provenientes do mar que predominam na costa brasileira. Estes ventos são mais frescos do que os ventos da terra, fato que propicia um clima excelente e poucas moléstias vigentes no Brasil.

No entanto, apesar de predominar o vento puro proveniente do mar, Gandavo nos relata que o vento da terra é muito perigoso e doentio, e se por acaso este vento permanece alguns dias, o que não é frequente, muita gente acaba por morrer, tanto os portugueses como os índios da terra. Tirado este mal, esta terra é muito saudável e de bons ares, onde as pessoas vivem por muitos anos e bem dispostas. ${ }^{154}$

Em outro trecho da obra "História da Província de Santa Cruz", Gandavo refere-se à benignidade predominante do clima brasileiro proporcionada pela Natureza:

Esta Provincia he à vista mui deliciosa e fresca em gram maneira: toda està vestida de mui alto e espesso arvoredo, regada com as águas de muitas e mui preciosas ribeiras de que abundantemente participa toda a terra, onde permanece sempre a verdura com aquella temperança da primavera que cá nos offerece Abril e Maio. E isto causa não haver là frios, nem ruinas de inverno que offendão as suas plantas, como cà offendem às nossas. Em fim que assi se houve a Natureza com todas as cousas desta Provincia, e de tal maneira se comedio na temperança dos ares, que nunca nella se sente frio nem quentura excessiva (1980, p. 82).

Este relato, no que se refere à inexistência dos excessos climáticos é, na verdade, um tema muito difundido durante as descrições medievais do Éden, conforme nos aponta Sérgio Buarque de Holanda em prefácio a segunda edição da "Visão do Paraíso", que "esta imagem do "non ibi frigus non aestus", que atravessa toda a Idade Média, chega aos tempos modernos. Tal ideia, que no Brasil, é retomada por Gandavo quando diz que nesta província de Santa Cruz de tal maneira foi comedida a natureza na temperança de seus ares, “que nunca se sente frio, nem quentura excessiva". Como ressonância daquelas palavras,

\footnotetext{
${ }^{153}$ GANDAVO, “Tratado da Terra do Brasil - História da Província de Santa Cruz”, 1980, p. 45.

${ }^{154}$ Ibidem, p. 45-46.
} 
também escreverá Fernão Cardim em um de seus "Tratados", que a terra do Brasil "geralmente não tem frios nem calmas". ${ }^{155}$

Como também explicita nesta passagem, Fernão Cardim, ao tratar do clima do Brasil, descreve sucintamente algumas representações da natureza brasileira e confirma a tese da sua benignidade climática ao alegar que:

O Clima do Brasil geralmente he temperado de bons, delicados, e salutiferos ares, donde os homens vivem muito até noventa, cento e mais annos, e a terra he cheia de velhos; geralmente não tem frios, nem calmas, ainda que do Rio de Janeiro até São Vicente ha frios, e calmas, mas não muito grandes; os céos são muitos puros e claros, principalmente de noite; a lua he muito prejudicial á saude, e corrompe muito as cousas; as manhãs são salutíferas, têm pouco de crepusculos, assi matutinos, como vespertinos, porque, em sendo manhã, logo sae o sol, e em se pondo logo anoitece. O inverno começa em Março, e acaba em Agosto, o Verão começa em Setembro e acaba em Fevereiro; as noites e dias são quasi todo o anno iguaes (1980, p. 25).

No diálogo segundo dos "Diálogos das Grandezas do Brasil”, Ambrósio Fernandes Brandão, através do interlocutor Alviano, declara ignorar a causa da morte dos naturais da terra ao serem levados a Portugal. Contudo, Brandônio argumenta que o fato de o gentio brasileiro não se dar bem em Portugal corrobora a razão do bom temperamento dos ares:

[...] como vão de terra tão sadia e de tão bons ares pera essa outra que lhes fica inferior em tanta cantidade, não soffre a natureza acostumada a tão excellente habitação e temperamento, como é a terra do Brasil, de onde os levam, padecer as injurias que o tempo com seus calores e frios causa na nossa Espanha, e por isso não se podem lograr nella, e vêm a perder a vida brevemente o que não succede ao gentio que se leva pera lá do reino de Angola e de todo Guiné, que, como vão de terra doentia e de ruim habitação, se contenta a sua natureza de gozar do clima de nossa Espanha que lhe sobrepuja em todas as calidades de mais sadia e isto mesmo succede ao gentio que se lá leva das Indias Orientaes; mas no Brasil se acha isto ao revez, porque toda gente de qualquer nação que seja prevalece nelle com saude perfeita, e os que vêm doentes cobram melhoria em breve tempo. E a razão é o serem estas terras do Brasil mais sadias e de melhor temperamento que todas as demais (1943, p. 115-116).

Brandônio continua a venerar o bom temperamento das terras do Brasil, tanto onde passa a linha equinocial, como nas demais áreas, e afirma ter esta convicção devido a sua experiência no Pará, também chamado o Rio das Amazonas, que se localiza nesta linha, e

${ }^{155}$ HOLANDA, "Visão do Paraíso", 1996, p. XIX - XX. 
nem por isso "deixa de ser mesmo temperada e sadia, e de maravilhosa habitação para a natureza humana, porque tem tão bom céo e goza de tão bons ares toda terra do Brasil" (BRANDÃO, 1943, p. 116).

Também apoia a tese dos "bons ares" encontrados em terras brasileiras Simão de Vasconcelos, quando em sua obra "Crônica da Companhia de Jesus", nos diz que na Bahia a região do ar é vital, “um quase segundo paraíso, uma perpétua primavera, onde raramente se sente excesso de frio, ou de calma, donde andam desterradas as pestes, e ramos delas, as doenças contagiosas; e sem esta injúria dos climas morrem os homens por seus cabais, cheios de dias, e de anos" (1977, v. 1, p. 190).

Esta ideia de clima ameno do "horto das delícias", já existente entre os gregos habitantes da planície de Mecona e da Arcádia, reaparece em Ovídio em sua obra "Metamorfoses", onde a humanidade primitiva, antes de inventar a agricultura, alimentavase dos frutos que as árvores espontaneamente produziam. Concepção também adotada por Virgílio, na obra "Geórgicas":

[...] antes de meter ferro a incognita campanha cumpre os ventos saber-lhe, a compleição dos ares, as praxes dos avós, o próprio dos lugares. [...]. Leis são, que a natureza, origem de harmonias, aos vários sitios pôz n'esses remotos dias, em que Deucalião ${ }^{156}$ pedras lançava aos ermos das quaes no duro ser provamos descendermos (VIRGÍLIO, 1930, p. 12-13).

Depois de constatada a tese predominante da benignidade dos climas do Brasil e de seus bons e salutíferos ares, aparece uma outra questão de fundamental importância referente à possibilidade de existir vida na chamada zona tórrida, que, segundo os antigos, era inabitável devido ao calor existente, questão que será analisada, debatida e concluída pela própria experiência dos cronistas e viajantes, como Simão de Vasconcelos e Ambrósio Fernandes Brandão.

Simão de Vasconcelos, em sua obra "Crônica da Companhia de Jesus", nos diz que a Bahia "está em altura de treze graus e meio, entre a linha, e trópico Austral; e contudo

\footnotetext{
156 VIRGÍLIO, “As Geórgicas”, 1930, p. 13, in notas de Antonio Feliciano de Castilho: “Júpiter decretado extinguir a humanidade por meio de um dilúvio, Deucalião ouviu os conselhos do oráculo de Delphos, que, para repovoar a terra, bastava que ele e sua esposa Pyrrha, arremessassem para trás as pedras, que eram os ossos de sua mãe terra, e, ao arremessá-las, viu que a terra se repovoava”.
} 
zombam seus naturais da doutrina dos antigos filósofos, que tinham para si que era inabitável esta parte do mundo" (1977, v. 1, p. 190).

No segundo diálogo dos "Diálogos das Grandezas do Brasil" se apresenta a questão da linha equinocial e de suas implicações climáticas, em que o interlocutor Brandônio afirma que esta linha não é outra coisa senão um círculo imaginado dos astrólogos na oitava esfera, que divide em duas metades iguais a chamada zona tórrida, localizada entre os trópicos, que possibilita regular os movimentos dos orbes celestes. ${ }^{157}$

Esta discussão sobre a inabitabilidade da zona tórrida afirmada pelos antigos filósofos é desmentida pela experiência de Ambrósio Fernandes Brandão. Alviano, que é o outro interlocutor de tal obra, diz duvidar que esta terra do Brasil seja de tão bom temperamento e tão sadia para a natureza humana, uma vez que a maior parte de sua costa se localiza na zona tórrida, tão vituperada pelos antigos. Contudo, Brandônio afirma que, apesar de grande parte da costa do Brasil estar localizada nesta zona e ser julgada pelos antigos por inabitável, ela se apresenta propícia para a humana natureza, devido à inexistência de uma brusca alternância de suas temperaturas. ${ }^{158}$

Brandônio assevera que Ptolomeu, Lucano, Averróis, bem como outros filósofos afirmaram erradamente ser a zona tórrida inabitável, por estar entre o Trópico de Câncer e o de Capricórnio. No entanto, Pedro Paduense, Alberto Magno e Avicena disseram ser terra habitável. Alviano acrescenta que devemos desculpar os filósofos que afirmaram a inabitabilidade da zona tórrida devido à falta de experiência em conhecer a costa brasileira, já que não puderam ter notícia dos ventos que por ela fluem. ${ }^{159}$

Ambrósio Fernandes Brandão principia por contestar a Ptolomeu e a seus discípulos sobre a inabitabilidade da tórrida zona, como nos afirma Rodolfo Garcia:

[...] no parecer de outros filósofos, [...] a intensidade daquele calor é moderada pelos ventos frescos que de ordinário cursam na mesma zona e por outras condições atmosféricas, bastantes para temperar os ares e tornar a vida humana [...] deliciosa. Fundado nessas razões, chega a assegurar que nenhuma parte do mundo é mais sadia e de melhor temperamento do que a terra do Brasil. E é tanto assim que não faltam autores que querem afirmar estar nesta parte situado o paraíso terreal (GARCIA apud BRANDÃO, 1943, p. 128). ${ }^{160}$

\footnotetext{
157 BRANDÃO, "Diálogos das Grandezas do Brasil”, 1943, p. 97.

${ }^{158}$ Ibidem, p. 94-95.

${ }^{159}$ Ibidem, p. 95 e 97.

${ }^{160}$ Rodolfo Garcia nos relata, em nota, que o diálogo segundo é dedicado à definição do clima do Brasil e para esta discussão, Brandão se utiliza de vasta bibliografia. Dentre elas, Aristóteles, que na "Física"
} 
Para se fazer justiça à terra do Brasil, Simão de Vasconcelos nos relata as bondades de que Deus a dotou e desfaz as calúnias realizadas em outros tempos por todos os sábios da Europa em desacreditar em tudo desta quarta parte do mundo. Ressalta que Aristóteles, no livro segundo de sua obra "Meteoros", foi o primeiro que infamou a zona tropical, ao dizer que ela corresponde à zona tórrida, e que era "terra inútil, seca, requeimada, e incapaz de fontes, rios, pastos, e arvoredos; e por conseguinte, deserta para sempre, e inabitável aos homens, pelos excessivos ardores causados da proximidade do sol, que anda sempre sobre ela" (1977, v. 1, p. 137-138).

A este filósofo seguiram Plínio, o Velho, que desacredita a mesma região por ser requeimada, tórrida, acesa dos veementes raios do sol e intratável à gente humana. Plínio, na obra "História Natural", nos assegura que a terra tem cinco zonas. Tudo o que está situado em torno a ambos os polos está coberto por um gelo eterno e um frio terrível, mas, pelo contrário, a zona central da terra, por onde passa a órbita do sol, é tórrida e queimada pelo calor que a cerca. Somente as zonas entre a tórrida e a fria são temperadas e habitáveis. ${ }^{161}$ Conforme introdução geral realizada por Guy Serbat à obra "História Natural", Plínio afirma claramente "la existencia de vastas zonas inexploradas, al Sur a causa del calor, al Norte a causa del frío” (Apud PLÍNIO, 1995, p. 77).

Para Virgílio, no livro primeiro de "As Geórgicas", se utiliza da mesma infâmia quando diz que "existem cinco zonas nos céos: a média, eternamente coruscante de sol, e em fogo eterno ardente" (VIRGÍLIO, 1930, p. 26). Tal interpretação também é apresentada por Ovídio no primeiro livro de suas "Metamorfoses": "aquela que das mais está no meio em calores inóspitos se abrasa" (OVÍDIO, 2003, p. 17). Esta tópica está literalmente presente na obra do cronista Simão de Vasconcelos ao citar Virgílio: "quinque tenent

apresenta os tratados do céu, dos meteoros e do mundo, e na "História Natural" os tratados dos animais e das plantas. Segue-se Cláudio Ptolomeu, cuja principal obra é o "Almagesto". Vem logo citado Lucano, filósofo grego que viveu no século V a.C., autor do tratado "Da natureza do Universo", dirigido a Platão. Também se refere à Averróis, que foi o introdutor de Aristóteles no Ocidente; a Alberto Magno que foi um dos comentadores de Aristóteles na Idade Média; e a Avicena, filósofo árabe, autor do Canon. Seguem-se ainda, o astrônomo Juntino, de quem se conhecem o Tractatus judicandi revolutionis nativitatum de 1570 e o Speculum astrologiae de 1580; Sacro-Bosco, monge inglês que viveu no século XIII e escreveu De sphera mundi, em 1472, a primeira obra de Astronomia divulgada no Ocidente após a queda de Roma; e Vatablo, que traduziu para o latim os Parva naturalis de Aristóteles; também, o botânico grego Dioscórides, com o tratado sobre medicina, além da Bíblia. Apud, BRANDÃO, "Diálogos das Grandezas do Brasil”, 1943, p. 128.

${ }^{161}$ PLÍNIO, "História Natural", 1995, p. 427-428. 
caelum Zona, quarum una corusco. Semper sole rubens, et torrida semper ab igne" (Apud VASCONCELOS, 1977, v.1, p. 138) e Ovídio: “Quarum quae media est, non est habitabilis aestu" (Apud VASCONCELOS, v. 1, 1977, p. 138).

O tratadista de História Natural Estrabão (64-2 a.C. a 23 d.C.) na obra "Geografia" nos relata que, em geografia, é natural a hipótese de que a Terra inteira tem forma de esfera, igual ao universo e a de que esta tem cinco zonas. Traz-nos que Posidônio atribui à Parmênides a autoria da divisão da Terra em cinco zonas, ainda que atribua à zona tórrida quase o dobro de sua largura. E que, segundo Aristóteles, (apud Estrabão, 1991, p. 451), chama-se de tórrida a zona situada entre os trópicos e de temperadas as situadas entre estes e os círculos árticos. Para Estrabão, mais da metade da largura do espaço compreendido entre os trópicos é habitável e as zonas mais meridionais têm uma atmosfera temperada com uma terra mais fértil; e chama de Tórrida a zona inabitável pelo calor. ${ }^{162}$

A divisão em cinco zonas para Estrabão se aplica tanto física, como geograficamente. Fisicamente porque está de acordo com os fenômenos celestes e com as condições atmosféricas, pois, ao julgar as condições da atmosfera com relação ao Sol, há três diferenças gerais e fortemente marcadas em respeito à disposição de animais e plantas e de tudo quanto vive: o excesso de calor na zona tórrida, sua falta nas zonas glaciais e o termo médio, nas zonas temperadas. A divisão também se aplica geograficamente, pois no centro é temperado para as plantas e seres vivos, ao mesmo tempo em que, a cada lado está pouco equilibrado por excesso ou por falta de calor. E para notar estas diferenças, é necessária a divisão em cinco zonas: seccionando a esfera terrestre por meio do Equador em duas partes, o hemisfério boreal e o austral; as regiões situadas no Equador e na zona tórrida são inabitáveis pelo calor e as situadas no polo, pelo frio; e as intermediárias são temperadas e habitáveis. ${ }^{163}$

Estrabão também rechaçava as pretensões de uma terra habitada ao sul do Equador. Para ele só a metade do hemisfério norte é habitável. Na natureza, por obra da Providência "tudo está em perpétuo movimento e sofre grandes transformações". Desde o século V, a teoria da influência do clima sobre todo tipo de vida vinha se estendendo. Em Estrabão, o duplo sentido de clima, referindo-se à latitude e ao clima, é patente, posto que a latitude

\footnotetext{
${ }^{162}$ ESTRABÃO, “Geografia”, 1991, p. 451.

${ }^{163}$ Ibidem, p. 455.
} 
determine o calor, o frio e as condições atmosféricas. A temperatura média e o excesso de calor ou de frio servem para determinar as zonas. ${ }^{164}$ Ao analisar a natureza das regiões tropicais, Estrabão relata que os que vivem no trópico vivem numa região arenosa e seca, ao mesmo tempo que as mais meridionais estão bem regadas e são férteis. ${ }^{165}$

No entanto, Simão de Vasconcelos, contraria grande parte dos filósofos antigos, ao afirmar que a chamada zona tórrida "é uma região temperada, amena, abundante de chuvas, orvalhos, fontes, rios, pastos, verdura, arvoredos e frutos para perfeita habitação de viventes como puderam constatar Colombo e Cabral que as descobriram" (1977, p. 141). Houve também muitos dos antigos, que chegaram a defender que nesta parte abaixo da linha Equinocial, Deus criara o Paraíso terrestre, tais como Eratóstenes, Prolíbio, Ptolomeu, Avicena e Santo Tomás. ${ }^{166}$

Como encontramos na obra "Visão do Paraíso", Holanda concorda com a constatação de Vasconcelos, ao apontar que muitos teólogos, entre eles o próprio Santo Tomás de Aquino, teriam colocado o paraíso debaixo da linha equinocial, dizendo ser a parte do mundo mais temperada, "mais deleitável e mais amena para a perfeita habitação dos homens. Sucede ainda que entre as regiões equatoriais, nenhuma, segundo o cronista da Companhia, tinha em si as bondades que mostra o Brasil” (1996, p. 142-143).

Assim como Frei Vicente do Salvador, na obra "História do Brasil - 1500-1627", resgata e acata o argumento de Aristóteles de que o sol esquenta mais na zona tórrida, mas que esta intensidade é moderada pelos ventos frescos do mar, pela umidade da terra e pela frescura do arvoredo, fazendo com que os homens vivam nesta terra alegremente. Deste modo, entra na defesa do "clima e temperamento do Brasil", em que a experiência tem mostrado

[...] que a zona tórrida é habitável, e que em algumas partes dela vivem os homens com mais saúde que em toda a zona temperada, principalmente no Brasil, onde nunca há peste nem outras enfermidades comuns, senão bexigas de tempos em tempos, de que adoecem os negros e os naturais da terra, e isto só uma vez sem a segundar em os que já as tiveram e, se alguns adoecem de enfermidades particulares, é mais por suas desordens que por malícia da terra (SALVADOR, 1982, p. 61).

\footnotetext{
${ }^{164}$ ESTRABÃO, “Geografia”, 1991, in: introdução geral de J. García Blanco.

165 ESTRABÃO, “Geografia”, 1991, p. 529.

${ }^{166}$ VASCONCELOS, “Crônica da Companhia de Jesus”, 1977, v. 1, p. 141.
} 
Outro fator comum, apontado por Simão de Vasconcelos, na região equinocial, é serem os dias iguais às noites, em que ficam quase temperados calor e frio. Como é o sítio da terra, mais alta e vizinha à meia região do ar, que é mais fria, ela fica mais isenta da repercussão dos raios do sol e,

[...] a maior vizinhança do mar, as virações contínuas vitais, e benignas, que comumente se experimentam, e é força mitiguem o calor: parece este singular dom de Deus, tirado dos tesouros de sua onipotência. [...] de que o Autor da natureza dotou a esta região do princípio do mundo, além da bondade dos astros (1977, v. 1, p. 143).

Deste modo, o Brasil se livra das calúnias impostas a ele, de que a nossa região nem é sem céu, nem a nossa terra é inútil, seca e tórrida, nem há falta de chuvas, fontes, rios, pastos e arvoredos, e nem deserta e inabitável aos humanos. Segundo Simão de Vasconcelos, é notório, em toda boa filosofia, que da bondade das propriedades provém a bondade do ser, que a terra se vista de verde, que contenha erva, pastos e arvoredos de variados; que tenha bom clima, boas influências do céu, do sol, da lua e das estrelas; que suas águas sejam abundantes de peixes e seus ares abundantes de aves e que produza todos os gêneros de animais. ${ }^{167}$ Deste modo, o Autor da natureza, prova que esta terra é boa:

[...] averiguada cousa, é que a bondade do clima de uma região, se há de contar pela maior felicidade dela; e que esta só, excede a todas; e que todas as que pode dar a natureza, cedem à bondade daquele. Porque como a bondade do clima, e da concórdia de suas quatro qualidades, dependa a vida, saúde, e contentamento dos viventes (VASCONCELOS, 1977, v. 1, p. 157-158).

A medida de toda a felicidade natural foi o estado do Paraíso terreno, que consistia no equilíbrio proporcionado dos quatro humores precedidos das quatro qualidades do clima. Vinculando a estes fatores o modo de vida naquela região, "quanto mais distante está cada qual das regiões do mundo daquele clima, e temperamento primeiro, tanto mais distante está daquela primeira felicidade" (VASCONCELOS, 1977, v. 1, p. 158). Para Simão de Vasconcelos, o estado do Brasil decaiu menos, porque a bondade do clima compõe-se da bondade dos astros que nele predominam, junto à bondade dos ares e melhor pasto dos viventes. ${ }^{168}$

\footnotetext{
${ }^{167}$ VASCONCELOS, “Crônica da Companhia de Jesus”, 1977, v. 1, p. 144.

${ }^{168}$ Ibidem, p. 158-159.
} 


\section{3 - A terra e as águas}

Uma visão que predomina entre os cronistas e viajantes em análise é a da abundância das terras, da sua boa fertilidade e da farta oferta de mantimentos. Também é característica geral desta terra do Brasil, segundo eles, a imensa quantidade e a pureza das águas, onde a natureza se apresenta de forma portentosa.

Deste modo, a combinação entre a quantidade de terras e a imensidade das águas serão muito aclamadas, como podemos averiguar nos dizeres de Gandavo que sua intenção não foi outra, senão denunciar a fertilidade e abundância da terra do Brasil, para que esta fama venha a ser conhecida por muitas pessoas pobres que vivem nestes reinos, por que esta terra é tão natural e favorável que a todos acolhe. ${ }^{169}$ Ao fazer uma análise geral das capitanias Gandavo nos diz que, nas capitanias de Ilhéus, de Porto Seguro, do Espírito Santo e do Rio de Janeiro existem muitas terras férteis aos seus entornos, muita caça e muitos peixes pelos rios junto às povoações, onde os moradores vivem abastados de mantimentos, sendo que:

Esta terra he mui fertil e viçosa, toda coberta de altissimos e frondosos arvoredos, permanece sempre a verdura nella no inverno e verão; isto causa chover-lhe muitas vezes e não haver frio que offenda ao que produz a terra. Ha por baixo destes arvoredos grande mato e mui basto e de tal maneira está escuro e serrado em partes que nunca participa o chão da quentura nem da claridade do Sol, e assi está sempre humido e manando agoa de si (1980, p. 46).

Gabriel Soares de Sousa, no "Tratado Descritivo do Brasil”, realiza um roteiro geral da costa brasílica, uma vez que a terra do Brasil "é quase toda muito fértil, mui sadia, fresca e lavada de bons ares e regada de frescas e frias águas" (1987, p. 39). Praticamente em todos os capítulos este cronista ressalta a boa qualidade e a ótima fertilidade da terra.

Simão de Vasconcelos relata aos reis D. Manuel e D. João III, as descrições de seus capitães e cosmógrafos das belas formas da costa do Brasil, das montanhas extraordinárias que começam a aparecer a partir da Capitania de Ilhéus até o Rio da Prata, onde "parece descansou a natureza um pouco e tornou logo a continuar com a fábrica desta máquina fatal do terreno, correndo com elas na mesma direitura [...] pelos Reinos de Chile, Quito, Peru e

${ }^{169}$ GANDAVO, “Tratado da Terra do Brasil - História da Província de Santa Cruz”, 1980, p. 22. 
Granada" (1977, v. 1, p. 78). A imensa altura destes informes montes é semelhante ao seu comprimento "parece que querem competir com o Céu: [...] ficam como em outro mundo, como se estivessem isentos da jurisdição dos tempos; qual do cume do monte Olimpo cantam os poetas" (VASCONCELOS, 1977, v. 1, p. 78).

Como também Santa Rita Durão, na obra "Caramuru”, faz alusão a imensidão de seus cumes,

[...] Tem a terra brasílica composta

De montes de grandeza desmedida:

Os Guararapes, Borborema posta

Sobre as nuvens na cima recrescida,

A serra de Aimorés, que ao pólo é raia,

As de Ibo-ti-catu e Itatiaia (2005, p. 214).

Logo que os portugueses chegaram ao Brasil, descreveram-no com muitas informações de uma geografia fantástica, falavam em montanhas tão altas que as aves não podiam transpô-las, em lagoas abundantes em pérolas e em um lago imenso de que nasciam o Amazonas, o São Francisco e o Prata. ${ }^{170}$

As montanhas foram sempre um marco que tiveram à vista aqueles homens empreendedores. Além disso, uma montanha abrange grande parte do país, e dela pode fazer-se um reconhecimento prévio do espaço a percorrer. Os rios foram os caminhos seguidos preferencialmente; estes garantiam a água, condição indispensável de vida, facilitavam a alimentação, diretamente pelos peixes e indiretamente pela caça que vem beber no seu leito. ${ }^{171}$

Do mesmo modo, Simão de Vasconcelos mostra-nos as propriedades da natureza brasileira, sendo que a terra do Brasil é:

[...] por excelência sempre verde, cheia de ervas e arvoredos, de vários gêneros, entre todas as mais terras do mundo, na conformidade do Texto de sua primeira criação. [...]. A primeira cousa que admiram os que de novo vêm a esta terra, é o enfeite de sua perpétua verdura, quer de inverno, quer de verão: parece estar sempre em uma eterna primavera, que recreia os olhos e convida as almas a louvar o Autor da natureza, porque sem dúvida excede nesta formosura a todas as outras partes do orbe, a essas só enfeita de meias a natureza na primavera, emprestando-lhes a tapeçaria, que no inverno lhes desarma. Porém a nossa parte enfeita de todo no verão, e inverno (1977, v. 1, p. 145).

\footnotetext{
${ }^{170}$ ABREU, “O descobrimento do Brasil”, 1999, p. 59-60.

${ }^{171}$ Ibidem, p. 64.
} 
E, especificamente ao tratar da Bahia, Simão de Vasconcelos nos descreve que a terra desse lugar é como:

um pintado mapa, sempre verde e sempre alegre; porque conservam todo o ano a folha seus arvoredos. Na compostura da natureza, bem assombrada, levantada em outeiros, estendida em campinas, povoada de bosques, abundante de pastos, retalhada de rios, fecunda de fontes, sempre a mesma, sempre vária; donde nasce, que é inumerável o gado, e todo o gênero de criação abundantíssimo (1977, v. 1, p. 189).

Nos "Diálogos das Grandezas do Brasil", de Ambrósio Fernandes Brandão, no momento em que Alviano relata a maldade da terra, Brandônio, indignado com tal incisiva, assevera o engano do colega diante de tal afirmação, porque a terra "é disposta pera se haver de fazer nella todas as agriculturas do mundo pela sua muita fertilidade, excellente clima, bons céus, disposição do seu temperamento, salutiferos ares, e outros mil attributos que se lhe ajuntam" (1943, p. 45).

Mas, Alviano prossegue dizendo que faz tanto tempo que esta terra é povoada de gente portuguesa que já deveriam ter descoberto esses segredos, e que se até agora não os acharam é por que nada há. Brandônio intentado a dar uma resposta cabal lhe diz que:

Não vêdes vós que o Brasil produz tanta quantidade de carnes domesticas e selvaticas, que abunda de tantas aves mansas, que se criam em casa, de toda sorte, e outras infinitas, que se acham pelos campos; tão grande abundancia de pescado excellentissimo, e de differentes castas e nomes; tantos mariscos e cangrejos que se colhem e tomam á custa de pouco trabalho; tanto leite que se tira dos gados; tanto mel que se acha nas arvores agrestes; ovos sem conto, fructas maravilhosas, cultivadas com pouco trabalho e outras sem nenhum que os campos dão liberalmente; tantos legumes de diversas castas, tanto mantimento de mandioca e arroz, com outras infinidades de cousas salutiferas e de muito nutrimento pera a natureza humana, que ainda espero de vo-las relatar mais em particular. Pois á terra que abunda de todas estas cousas como se lhe póde attribuir falta dellas? (BRANDÃO, 1943, p. 45).

Já no diálogo terceiro, Alviano pede a Brandônio para tratar da riqueza, fertilidade e abundância da terra deste Brasil; Brandônio the diz que são grandes as riquezas da terra deste novo mundo, sua fertilidade e abundância, e que as riquezas do Brasil consistem em 
seis coisas: a lavoura de açúcar, o comércio, o pau-Brasil, os algodões e madeiras, a lavoura de mantimentos e a criação de gados. ${ }^{172}$

No quarto diálogo, Ambrósio Fernandes Brandão nos descreve ligeiros quadros da vida vegetal, relata que o milho que dá nesta terra é melhor e em maior quantidade do que em Portugal, mas aqui não é tanto utilizado, porque a gente da terra se contenta somente com aquilo que os antepassados deixaram em uso, sem quererem criar outras novidades. E ressalta Alviano que "são todos ingratos a Deus, em não saberem aproveitar dos benefícios que lhes faz e promette neste Estado" (1943, p. 195).

Além da abundância e da fertilidade das terras do Brasil, os cronistas e viajantes tecem grandes louvores ao descreverem a quantidade e a qualidade das águas aqui encontradas. São unânimes ao afirmar que elas são fartas e de ótima qualidade. Segundo Pero Vaz de Caminha, as águas encontradas em terras brasileiras "sam mujtas jmfimdas. E em tal maneira he graciosa que querendoa aproveitar darsea neela tudo per bem das agoas que tem" (CAMINHA, 1968, p. 56). Ou, também, como nos descreve Santa Rita Durão, na obra "Caramuru" que,

Vêm-se dentro campinas deleitosas,

Geladas fontes, árvores copadas,

Outeiros de cristal, campos de rosas,

Mil frutíferas plantas delicadas:

Coberto o chão das frutas mais mimosas,

E à maneira, entre as flores, de serpentes,

Vão volteando as líquidas correntes (2005, p. 95)

Gabriel Soares de Sousa, na primeira parte do "Tratado Descritivo do Brasil", realiza um roteiro geral da costa brasílica, uma vez que o Brasil

[...] está capaz para se edificar nele um grande império, o qual com pouca despesa destes reinos se fará tão soberano que seja um dos Estados do mundo porque terá de costa mais de mil léguas [...] e regada de frescas e frias águas. Pela qual costa tem muitos, mui seguros e grandes portos, para nele entrarem grandes armadas, com muita facilidade, para as quais tem mais quantidade de madeira que nenhuma parte do mundo (1987, p. 39-40).

${ }^{172}$ BRANDÃO, "Diálogos das Grandezas do Brasil”, 1943, p. 138. 
Entre os cronistas e viajantes analisados, é Simão de Vasconcelos, na obra "Crônica da Companhia de Jesus", quem faz os maiores louvores às águas encontradas no Brasil. Ele nos diz que o território brasileiro tem seu princípio junto ao rio das Amazonas ou GrãoPará e vai até o rio da Prata. Ambos os rios são portentos da natureza, sendo que, o rio Amazonas

[...] é o Imperador de todos os rios do mundo; e qualquer dos que celebra a antiguidade, à vista deste fica sendo um pequeno pigmeu em comparação de um grande gigante. Chamam-lhe os naturais Paraguaçu, que quer dizer mar grande: e tem razão, pois para ser um mar, falta-lhe só serem suas águas salgadas (1977, v. 1, p. 61).

Vários autores e moradores da Capitania de São Paulo que excursionaram por este grande rio, dizem coisas maravilhosas "que nenhum pecado cometeriam os que dissessem que, junto a este rio, plantará Deus Nosso Senhor o Paraíso terreal”, conforme louvor de Simão de Vasconcelos (1977, v. 1, p. 65).

Ambrósio Fernandes Brandão nos relata, através de Brandônio, que as nascentes do rio Amazonas provêm segundo "os naturaes da terra [...] de uma alagoa, que dizem estar no meio do sertão, de onde affirmam nascerem os demais rios reaes e caudalosos, que sabemos por toda esta costa do Brasil” (1943, p. 50).

Tais rios da costa do Brasil, vindos do sertão com suas poderosas águas, se fossem todos descritos, como afirma Simão de Vasconcelos, seriam necessários livros inteiros, porque "todo o sertão está feito um bosque, entretalhado como em canteiros, da mesma natureza, com suas águas: e a praia toda se vê autorizada com a grandeza e variedade de suas bocas, barras, baías, enseadas e alagoas” (1977, v. 1, p. 67).

É visão comum entre os cronistas e viajantes que os rios aqui encontrados em terras brasileiras são inúmeros, caudalosos e repletos de peixes. Segundo nos informa Simão de Vasconcelos, os rios Maranhão e Grande possuem águas abundantes provenientes de uma lagoa formosa na qual afirmam os naturais existirem preciosas pérolas. Logo ao sul do Rio Grande encontra-se o rio Jaguaribe e o Beberibe, junto ao qual foi fundada a vila do Recife e, próximo a ela, a vila de Olinda. ${ }^{173}$

${ }^{173}$ VASCONCELOS, “Crônica da Companhia de Jesus”, 1977, v. 1, p. 67-68. 
Pero de Magalhães Gandavo, na obra "Tratado da Terra do Brasil" diz que entre a capitania de Pernambuco e a Bahia há dois grandes rios caudalosos, um chamado São Francisco e o outro Real. ${ }^{174}$ Este cronista realça, entre outros rios, o Paraíba na capitania do Espírito Santo, por ser muito grande, formoso e com infinitos peixes. Nos diz também, que há na capitania do Rio de Janeiro um rio muito largo, no qual há muita terra aproveitável ao seu redor, tanto para cultivo de mantimentos como para cana-de-açúcar e algodão.

Do Cabo de Santo Agostinho até o formoso rio São Francisco, desembocam dez outros rios. No entanto, o São Francisco, que já reconhecido por Simão de Vasconcelos como um dos mais célebres do Brasil, provém da famosa lagoa formada pelas águas das serras do Chile e Peru, de onde procedem os rios Grão-Pará e da Prata. O rio São Francisco é navegável até quarenta léguas pelo sertão, até ser visível um mar de águas em sua cachoeira, após ela, as águas deste rio continuam navegáveis até chegar ao sumidouro:

[...] é este sumidouro uma notável invenção com que saiu a natureza, porque vai sorvendo todo este rio com suas grandes águas, pelas cavernas de uma furna medonha subterrânea, aonde se escondem de maneira, que não se vê mais rastro delas, senão quando, depois de passadas doze léguas, é visto tornar a rebentar com o mesmo brio, e poder das águas. [...] Do sumidouro para cima é da mesma maneira navegável [...]. Os arvoredos destas ribeiras vão-se às nuvens; tudo é um bosque, em muitas partes tão fechado que impede o céu, e a luz (1977, v. 1, p. 69$)$.

Na capitania da Bahia temos os rios Tinharé e Camamu, em que há terras muito viçosas e muitas águas com abundância de peixes e caça. Nos Ilhéus, segundo Gandavo, há uma imensa lagoa doce em que nasce um rio com abundância de água, nela "tem muita infinidade de peixes grandes e pequenos. Crião-se nella muitos Peixes-bois" (1980, p. 2930). Da Bahia para o sul, formoseiam as praias vinte rios de águas belíssimas, sendo que muitos destes são caudalosos, em que só esta região do Brasil daria para formar um reino. ${ }^{175}$

A região que vai desde o rio Santa Cruz até o rio Doce, os inúmeros e caudalosos rios que ali chegam, são descritos por Vasconcelos devido a abundância de peixes e a fertilidade das terras ao entorno. Do rio Doce até chegar ao Cabo Frio existe uma baía, "obra particular da natureza, cavada como de propósito entre o duro de uma penedia, que lhe serve de muro e fortaleza em sua entrada" (1977, v. 1, p. 74). Havia também um rio

\footnotetext{
${ }^{174}$ GANDAVO, "Tratado da Terra do Brasil - História da Província de Santa Cruz”, 1980, p. 27.

${ }^{175}$ VASCONCELOS, “Crônica da Companhia de Jesus”, 1977, v. 1, p. 71.
} 
entre estes, chamado Espírito Santo, acompanhado de uma vila de mesmo nome, cheio de terras férteis e abundantes, é, sobretudo, defensável, porque de uma parte a outra "muralhas altíssimas de penedia tosca da natureza, assombro de inimigos" (1977, v. 1, p. 74).

Já o rio Paraíba das serras de Piratininga, desemboca no mar onde a natureza lhe concedeu saída, "cobertas de arvoredo que sobe ao céu” (VASCONCELOS, 1977, v. 1, p. 74). Para leste de Cabo Frio está o rio a que os índios chamavam Niterói. É uma baía espaçosa, limpa e segura, em que foi edificada a cidade do Rio de Janeiro, ao sul encontrase o rio São Vicente, onde se edificou a vila de mesmo nome. E, desde o rio Cananéia ao da Prata se estende uma formosa parte da terra do Brasil com duzentas léguas. ${ }^{176}$

Também nos faz importante relato da imensidade das águas existentes no Brasil, Santa Rita Durão, nas estrofes que se seguem:

Nos vastos rios e altas alagoas Mares dentro das terras representa; Coberto o Grão-Pará de mil canoas, Tem na espantosa foz léguas oitenta. Por dezessete se deságua boas O vasto Maranhão; léguas quarenta O Jaguaribe dista; outro se engrossa De S. Francisco, com que o mar se adoça.

O Sergipe, o real de licor puro, Que com vinte o sertão regando correm, Santa Cruz, que no porto entra seguro, Depois de trinta, que no mar concorrem; Logo o das Contas, o Taigipe impuro, Que abrindo a vasta foz no oceano morrem, O Rio Doce, a Cananéia, a Prata, E outros cinqüenta mais, com que arremata (2005, p. 214-215).

De forma geral, os Cronistas e Viajantes analisados nos afirmam, conforme o exposto, que as águas do Brasil são infindas, límpidas e de ótima qualidade, configurando um dos motivos para que nesta terra se forme um poderoso império.

\footnotetext{
${ }^{176}$ VASCONCELOS, “Crônica da Companhia de Jesus”, 1977, v. 1, p. 75.
} 


\section{4 - A Vegetação}

A vegetação descrita pelos cronistas e viajantes no Brasil é geralmente exuberante, sempre verde, tanto no inverno quanto no verão, e de aprazível formosura.

Segundo Simão de Vasconcelos, há no Brasil dois gêneros de verdura, conforme o Divino Texto, que são as ervas e os verdes arvoredos, que saíram das mãos do criador. A bondade dos arvoredos do Brasil é bem conhecida, devido a sua formosura, é "ornato da terra e, abono das mãos do Criador, ver aquelas matas imensas, glória, e coroa de todo o arvoredo do universo, os pés na terra, as copas no Céu, formando bosques deleitosos, brutescos sombrios, os mais agradáveis do mundo" (1977, v. 1, p. 146).

Fernão Cardim assegura que, no Brasil não semeiam o trigo, o pão é feito com a farinha de mandioca e com milho zaburro que há na terra, em todas as Capitanias, e os bolos são feitos com aipim, que é uma raiz encontrada em abundância. Há nesta terra muito arroz, fava, feijões, inhames e batatas, e outros legumes que fartam muito a terra; com estes mantimentos se sustentam os moradores do Brasil. Há muitas frutas neste reino, tais como: melões, pepinos, figos, romãs, parreiras que várias vezes ao ano dão uvas, limões e laranjas há uma infinidade, desta maneira, salienta que o Brasil nunca fica sem frutas. ${ }^{177}$ Também nos diz que legumes e hortaliças não faltam nesta terra, tais como berinjelas, alfaces, couves, abóboras, dentre outros. ${ }^{178}$

Nos "Diálogos das grandezas do Brasil”, Ambrósio Fernandes Brandão louva a grandeza, a excelência e a amenidade da selva brasileira ao dizer que:

[...] por toda parte que ponho os olhos, vejo frondosas arvores, entrebastecidas matas e intricadas selvas, amenos campos, composto tudo de uma doce e suave primavera; porquanto, em todo o decurso do anno, gozam as arvores de uma fresca verdura, e tão verdes se mostram no verão como no inverno, sem nunca se despirem de todo de suas folhas, como costumam de fazer na nossa Espanha; antes, tanto que lhe cahe uma, the nasce immediatamente outra, campeando a vista com formosas paizagens, [...] porque aqui as matas, e bosques são naturaes, e não industriosos, acompanhados de tão crescidos arvoredos, que, além de suas tapadas, frescas folhas defendem aos raios do sol poder visitar o terreno de que gozam, não é bastante uma flecha despedida de um teso arco por galhardo braço, a poder sobrepujar a sua alteza; e destas semelhantes plantas e arvores ha tantas e diversas castas que se

\footnotetext{
177 GANDAVO, “Tratado da Terra do Brasil - História da Província de Santa Cruz", 1980, p. 48.

${ }^{178}$ CARDIM, “Tratados da terra e gente do Brasil”, 1980, p. 144.
} 
embaraçam os olhos na contemplação dellas, e somente se satisfazem com dar graças a Deus de as haver criado daquella sorte. Donde certamente cuido que se neste Brasil houvera bons arbolarios, se poderiam fazer da qualidade e natureza das plantas e arvores muitos volumes de livros maiores que os de Dioscorides; porque gozam e encerram em si grandissimas virtudes e excellencias occultas, e enxerga-se o seu mérito em algumas poucas dellas, de que nos aproveitamos (1943, p. 165-166).

Alviano acata a exposição de Brandônio e afirma que, desta forma, "temos no Brasil como novos campos de Thesalia; porque tendes encarecido os seus com tão efficazes palavras, que me vem o desejo de me transformar em um agreste pastor, sómente pera poder gozar de tanta frescura" (BRANDÃO, 1943, p. 166).

Conforme Capistrano de Abreu, Pero de Magalhães Gandavo está convicto de que sob a aparência das coisas se escondem mistérios, uma vez apenas indicando-os, outras vezes revelando-os, ${ }^{179}$ como no caso da banana, que há na terra em abundância, sendo que a qualidade das pequenas "têm dentro em si huma cousa estranha, a qual he que quando as cortão pelo meio com huma faca ou por qualquer parte que seja, acha-se nellas hum signal á maneira de Crucifixo, e assi totalmente o parecem" (GANDAVO, 1980, p. 51). Na obra “Tratados da terra e gente do Brasil”, Fernão Cardim ao tratar da pacoba nos diz que

Esta he a figueira que dizem de Adão, nem he arvore, nem erva, porque por huma parte se faz muito grossa, e cresce até vinte palmos em alto; o talo he muito molle, e poroso, as folhas que deita são formosissimas e algumas de comprimento de huma braça, e mais, todas rachadas como veludo de Bragança, tão finas que se escreve nellas, tão verdes, e frias, e frescas que deitando-se um doente de febres sobre ellas fica a febre temperada com sua frialdade (1980, p. 42).

Reaparece em Cardim a mesma visão que já havíamos percebido em Gandavo, de uma flora que se estende aos homens como um livro da natureza que expressa os desígnios divinos e que também nos descreverá Gabriel Soares de Sousa na segunda parte do “Tratado Descritivo do Brasil”, em que objetiva realizar um memorial e declaração das grandezas da Bahia e de sua fertilidade, ao nos relatar "que a pacoba é uma fruta natural desta terra, a qual se dá em uma árvore muito mole e fácil de cortar” (1987, p. 188), e que, as bananeiras "têm árvores, folhas e criação como as pacobeiras, e não há nas árvores de

\footnotetext{
${ }^{179}$ CAPISTRANO, "Prefácio", apud GANDAVO, "Tratado da Terra do Brasil - História da Província de Santa Cruz", 1980, p. 15.
} 
umas às outras nenhuma diferença, as quais foram ao Brasil de São Tomé [...] quem as cortar atravessadas, ver-lhes-á no meio uma feição de crucifixo, sobre o que contemplativos têm muito que dizer" (SOUSA, 1987, p. 189).

Diante de tais descrições vemos a presença da noção de utilidade, a busca dos significados da natureza, bem como as comparações com a flora europeia já conhecida por eles. Como podemos notar claramente em Fernão Cardim, Gabriel Soares e Simão de Vasconcelos, que referenciam à ótima fertilidade da terra do Brasil e de suas inúmeras frutas, e tratam especialmente das pacobas e dos ananases, que são frutas "de bom gosto, cheiram bem, para dôr de pedra são salutíferos” (CARDIM, 1980, p. 144). E também, Gabriel Soares de Souza nos relata que o ananás é uma fruta mais cumprida que uma cidra grande e lembra uma alcachofra, cuja "a natureza deste fruto é quente e úmida, e muito danosa para quem tem ferida ou chaga aberta" (1987, p. 200-201). Simão de Vasconcelos nos informa que uma das espécies mais "galante, e causa de louvar o Autor da natureza é, a que chamamos ananás; seu fruto é a modo de pinha de Portugal; [...]. A cabeça do fruto galanteou a natureza com um penacho, ou grinalda de cores aprazíveis" (1977, p. 147).

Em sintonia com a visão do Paraíso, na obra "Caramuru”, Santa Rita Durão também trata das qualidades de nossas frutas e declara que a mais louvada "é o régio ananás fruta tão boa,/ que a mesma natureza namorada/ quis como a rei cingi-la da coroa:/ tão grato cheiro dá, que uma talhada/ surpreende o olfato de qualquer pessoa;/ que a não ser do ananás distinto aviso,/ fragrância a cuidará do paraíso" (2006, p. 221).

É acerca deste simbolismo divino inserido neste imenso livro da natureza, observado principalmente na fauna e na flora, que D. Antonio de León Pinelo, na obra "El Paraiso en el Nuevo Mundo”, ao tratar do maracujá nos relata:

[...] que assim como emprega Deus a providência no bem e a favor do homem, também insinua, embora secreto e oculto, o reparo, antes mesmo do dano cometido. Nasceu esse da fruta, a que naturalmente precede a flor, de sorte que, pondo na flor insígnias e sinas do remédio, pode-se, com piedade, entender que a antepôs à culpa, prevenindo, senão o socorro, para deixar o homem em mãos de seu alvedrio, a promessa para o caso de cair, como caiu. E assim, com grandes fundamentos, podemos dizer (não afirmar) que essa fruta, que com tantos mistérios produz a natureza, foi aquela com que quebrou Adão o preceito divino. E que não se achando, como não se acha, senão nas Índias ibéricas, é argumento em favor da idéia de que pode nelas estar o Paraíso Terreno (Apud HOLANDA, 1996, p. 235). 
Gabriel Soares de Sousa nos descreve os benefícios medicinais proporcionados pelo maracujá, cujas folhas serviam para aliviar as chagas, que foi também descrita por Fernão Cardim, evidenciando que a flor-da-paixão tem um odor e sabor proveitosos para a saúde e é um ótimo remédio para as boubas "pois que, fria de sua natureza, se recomenda contra as febres" (Apud HOLANDA, 1996, p. 237-238).

Simão de Vasconcelos corrobora a mesma visão de Sérgio Buarque de Holanda, ao afirmar o que já nos havia dito Gandavo e Cardim, isto é, que uma das espécies de plantas singulares em todo o mundo, como a um brinco da natureza e devoção da piedade cristã, é a erva da Paixão, chamada pelos índios maracujá, cuja folha é das mais agradáveis e frescas do Brasil e, devido a este fato, sua sombra mais apetecida. "A flor é o mistério único das flores. Tem o tamanho de uma grande rosa e neste breve campo formou a natureza um como teatro dos mistérios da Redenção do mundo" (VASCONCELOS, 1977, v. 1, p. 151), nos explicita que a esta flor chamam da Paixão "porque mostra aos homens os principais instrumentos dela; que são a coroa, coluna, açoites, cravos e chagas” (1977, v. 1, p. 152).

Santa Rita Durão, numa bela passagem, conclama encantadamente a bela flor do maracujá, em que novamente aparecem inscritos os símbolos e sinais divinos:

Nem tu me esquecerás, flor admirada,/ em quem não sei se a graça, se a natura/ fez da Paixão do Redentor sagrado uma formosa e natural pintura [...]/ Com densa cópia a folha se derrama,/ que muito à vulgar hera é parecida,/ entressachando pela verde rama/ mil quadros da paixão do Autor da vida:/ milagre natural, que a mente chama/ com impulsos da graça, que a convida,/ a pintar sobre a flor aos nossos olhos/ a cruz de Cristo, as chagas e os abrolhos./ [...] Prodígio raro, estranha maravilha,/ com que tanto mistério se retrata!/ Onde em meio das trevas a fé brilha,/ que tanto desconhece a gente ingrata:/ assim do lado seu nascendo filha/ a humana espécie, Deus piedoso trata,/ e faz que quando a graça em si despreza,/ lhe pregue co'esta flor a natureza (2006, p. 219220).

Ambrósio Fernandes Brandão, na obra "Diálogos das Grandezas do Brasil”, nos diz através de Brandônio que há muitas flores, tais como a flor da laranjeira, que se dá em grande abundância, ou a flor chamada camará-açu, mas, a mais estimada é a flor do maracujá, devido a sua formosura e variedade de cores que a compõe. Há uma infinidade 
de flores que a terra naturalmente produz, que ele nem se atreve a tratar de todas elas. Alviano declara estar admirado, porque não pintava o Brasil assim. ${ }^{180}$

Também, nos notifica da formosura desta flor Frei Vicente do Salvador, na obra "História do Brasil", ao dizer que é misteriosa, visto que começa com três folhinhas, que representa as três divinas pessoas em uma divindade ou os três cravos com que Cristo foi encravado, e abaixo outras cinco folhas "que se rematam em uma roxa coroa, representando as cinco chagas e coroa de espinhos de Cristo Nosso Redentor" (1982, p. 66-67). Uma correlação existente entre a temática do Paraíso e da maçã ou maracujá, é realizada por Sérgio Buarque de Holanda, que semelhante ao verdadeiro Éden, a árvore da ciência do bem e do mal, não seria a maçã, e sim, o maracujá. ${ }^{181}$

É notadamente descrito pelos cronistas, ao se referirem à vegetação brasileira, que ela é exuberante, por conter muitas qualidades medicinais, com grande variedade de espécies e misteriosamente manifesta, como se fora um livro aberto, cabendo ao homem cristão não só a incógnita tarefa de decifrar seus símbolos, mas também a divina arte de contemplar a natureza. Eles também se referem à enorme diversidade da flora e as classifica em vários tipos, tais como as espécies arbóreas, arbustivas, ervas, trepadeiras dentre outras.

Segundo Simão de Vasconcelos, as árvores do Brasil são frutíferas, verdes em todo ano e muito aprazíveis, algumas destas que se encontram pelas matas, além da natural verdura, se enfeitam de formosas flores que ao vermos todas juntas "parece que se pôs à natureza a debuxar a mais pintada primavera" (1977, v. 1, p. 156).

Pero de Magalhães Gandavo, na obra "História da Província de Santa Cruz", nos relata que há uma fruta que nasce pelo mato, numas árvores grandes como pereiras ou macieiras, chamada caju, tem muito sumo e come-se para se refrescar do calor, "porque sua natureza é muito fria” (1980, p. 98). Também, Gabriel Soares de Sousa nos informa que os cajueiros são árvores muito estimadas, que têm umas frutas chamadas cajus, cuja natureza é fria e são medicinais. E também cria a natureza no olho deste pomo uma castanha, que tem a casca muito dura e de natureza quentíssima. ${ }^{182}$

\footnotetext{
${ }^{180}$ BRANDÃO, "Diálogos das Grandezas do Brasil”, 1943, p. 212.

${ }^{181}$ HOLANDA, "Visão do Paraíso", 1996, p. 140.

182 SOUSA, "Tratado Descritivo do Brasil", 1987, p. 187.
} 
Muitas outras árvores têm fins medicinais e são constituídas de grandes virtudes, como nos descreve Gabriel Soares de Sousa, ao tratar de algumas árvores de fruto que vivem próximas ao mar da Bahia, chamadas mangabeiras, que propiciam boa digestão, cuja natureza é fria, pelo que é muito boa para os doentes de febres por ser muito leve. Há também o cajá, que é uma árvore comprida, contém uma fruta de sabor precioso, cuja natureza é fria e sadia; dá-se esta fruta aos doentes de febres, por ser fria e apetitosa. Este cronista também faz importante referência à árvore dos umbus, encontrada pelo sertão da Bahia, em plena caatinga, que tem a terra seca, "onde a natureza criou a estas árvores para remédio da sede que os índios por ali passam" (SOUSA, 1987, p. 192). Podemos constatar assim, que o conceito de natureza é empregado como algo imanente ao ser, cuja finalidade é servir de remédio aos enfermos.

Uma concepção semelhante a esta é observada em Ambrósio Fernandes Brandão, na obra "Diálogos das Grandezas do Brasil", através do interlocutor Brandônio, ao nos dizer que, quando o gentil natural da terra é ferido nas guerras, proveu a natureza em lhes dar um azeite retirado da árvore chamada copaúba, que serve para curar as feridas, por ter uma maravilhosa virtude. ${ }^{183}$

No primeiro diálogo realizado entre Brandônio e Alviano, ao fazerem referência sobre uma lanugem produzida por uma árvore que dá um fruto semelhante à lã, eles chegam à conclusão que ainda há muitas coisas por descobrir, como frutos e minerais, e segredos não achados que ainda irão se manifestar, que os homens não alcançaram sua propriedade e natureza, visto que sabem muito bem que "as cousas todas foram produzidas de um principio, o qual foi a primeira criação que nellas fez Deus” (BRANDÃO, p. 40).

Gandavo trata de uma notável erva, chamada erva viva, cuja qualidade causará grande espanto, pois quando alguém lhe toca, naquele momento ela se encolhe e murcha de maneira que parece criatura sensitiva que se enoja, mas passado algum tempo, torna lentamente a estender-se até ficar outra vez como antes. Segundo ele,

[...] esta planta deve ter alguma virtude mui grande, a nós enconberta, cujo effeto nam será pela ventura de menos admiraçam. Porque sabemos de todas as hervas que Deos criou, ter cada huma particular virtude com que fizessem diversas operações naquellas cousas pera cuja utilidade foram criadas e quanto

${ }^{183}$ BRANDÃO, "Diálogos das Grandezas do Brasil”, 1943, p. 123. 
mais esta a que a natureza nisto tanto quiz assinalar dando-lhe hum tam estranho ser e differente de todas as outras (1980, p. 101).

Ao tratar desta erva, considerada sensitiva por Gandavo, Simão de Vasconcelos afirma ser "planta êmula do sol: enquanto ele vive, vive ela e em se pondo, com ele se sepulta, $[\ldots]$ até passar o triste da noite e tornar o alegre do dia: segredo só do Autor que a fez" (1977, v. 1, p. 151).

Também alude as qualidades ocultas da erva viva, Frei Vicente do Salvador, ao afirmar que podem chamar de sensitiva:

Se o não contradissera a filosofia, a qual ensina o sensitivo ser diferença genérica que distingue o animal da planta, assi se define o animal, que é corpo vivente sensitivo. Mas contra isto vemos que, se tocam esta erva com a mão ou com qualquer outra coisa, se encolhe logo e se murcha, como se sentira o toque, e depois que a largam, como já esquecida do agravo que lhe fizeram, se torna a estender e abrir as folhas. Deve isto ser alguma qualidade oculta (1982, p. 68).

No “Tratado Descritivo do Brasil em 1587”, segundo Gabriel Soares há relatos das qualidades das ervas de virtude que se criam na Bahia, como a erva-santa e outras ervas como o petume. Afirmam os índios que, quando andam pelo mato e lhes faltam mantimentos, matam a fome e a sede com este fumo, que tem virtude contra a asma, cuja natureza é muito quente. ${ }^{184}$

Daremos por encerrada a descrição da vegetação, especificamente das ervas, com o relato de Santa Rita Durão que "outras mil ervas, que se usar quiseres, acharás na opulenta natureza" (2005, p. 217).

${ }^{184}$ SOUSA, “Tratado Descritivo do Brasil em 1587”, 1987, p. 206. 


\section{5 - Os animais}

A fauna brasileira é descrita pelos cronistas e viajantes como riquíssima e de variadas espécies. No entanto, o que os cronistas chamam de animais são somente os animais terrestres ou aquáticos, porque as aves e os peixes recebem uma denominação própria, como se não fizessem parte do reino animal, como hoje em dia são classificados. Mas, de uma maneira geral, a fauna do Brasil é muito rica em insetos, répteis, aves, peixes e em pequenos animais, como nos descrevem incansavelmente.

Os primeiros animais vistos em terras brasileiras foram descritos por Pero Vaz de Caminha, na chegada da frota cabralina, numa quarta-feira, em abril de 1500: "topamos aves aque chamã fura buchos" (1968, p. 08). Ele também relata que enquanto andavam na mata a cortar lenha, atravessavam por entre as árvores alguns papagaios, uns verdes e outros pardos, grandes e pequenos, de que há muitos por esta terra; porém outras aves não viam, somente algumas pombas seixas, as quais pareciam maiores e em maior quantidade do que as de Portugal. ${ }^{185}$

Gandavo também nos informa que há muitos bichos nesta terra, sendo impossível conhecer e escrever tamanha quantidade, devido a vastidão do território e a diversidade de qualidades e aparências das criaturas que Deus nela criou. ${ }^{186} \mathrm{Na}$ obra "Caramuru", Santa Rita Durão também fará menção a grande quantidade e variedade de animais: "Nutre a vasta região raros viventes/ Em número sem conto e em natureza/ Dos nossos animais tão diferentes, Que enchem a vista da maior surpresa” (2005, p. 225).

Simão de Vasconcelos nos esclarece em seus escritos, que os exploradores portugueses viram somente o litoral brasileiro, estas eternas aparências, e só com elas ficaram admirados; mas, se penetrassem aos seus interiores e vissem a multidão de feras que por ali se criam, cansariam de contar as espécies de animais nocivos, tais como

[...] tigres, onças, gatos silvestres, serpentes, cobras, crocodilos e raposas. Outras de animais de caça, antas, veados, porcos monteses, e aquários, pacas, tatus, tamanduás, lebres e coelhos [...]. Outras de animais de gosto, e recreação, monos, macacos, bugios, sagüis, preguiças, cotias e outras espécies sem conto. Veriam aves as mais formosas, e numerosas, que se vêem em alguma parte do mundo. [...] admiráveis em variedade, penas, cores e formosura (1977, p. 79).

\footnotetext{
185 Apud ABREU, “O descobrimento do Brasil”, 1999, p. 186.

${ }^{186}$ GANDAVO, “Tratado da Terra do Brasil - História da Província de Santa Cruz”, 1980, p. 62.
} 
Fernão Cardim afirma que este Brasil já é outro Portugal, melhor no clima, que é muito mais sadio, no mar que tem muito mais pescado e nas coisas da terra provenientes de Deus, bem como, pelas muitas comodidades que os homens têm para viver. ${ }^{187}$ Também, comenta Brandônio que, se quisermos ouvir as naturezas e qualidades dos animais que naturalmente habitam esta terra, provavelmente nos causará espanto, tanto pela quantidade, quanto pela estranheza, desconhecidos no mundo e diferentes em sua natureza. Deste modo, ele afirma não querer se meter no labirinto de tratar das várias castas, estranhas feições e difíceis nomes das feras de que é povoado todo este imenso Brasil. ${ }^{188}$

Pero de Magalhães Gandavo nos assegura que existem no Brasil muitos animais de vários gêneros para sustentar os moradores desta terra. Há muitos veados, antas, capivaras, coelhos e pacas que têm carne muito saborosa, como também porcos monteses de variadas castas, sendo que os mais interessantes são uns porcos menores que têm o umbigo nas costas, e outros que vivem na terra e andam debaixo da água o tempo que quiserem, visto que, como correm pouco por terem os pés compridos e as mãos curtas, proveu a natureza de maneira que pudessem viver debaixo da água. ${ }^{189}$ Corrobora com esta análise referente à estranha característica dos porcos o interlocutor Brandônio, nos "Diálogos das Grandezas do Brasil", ao nos informar que há uma casta chamada teaçu e outra tahitetê, que têm os umbigos nas costas, porque parece que assim os criou a natureza. ${ }^{190}$

Outra característica que perpassa as obras destes cronistas analisados é a maneira como eles descrevem alguns dos animais totalmente estranhos ao mundo europeu, como nesta menção realizada por Pero de Magalhães Gandavo, na obra "Tratado da Terra do Brasil" quando diz que há uns bichos encontrados nesta terra, chamados tatus, que,

[...] são do tamanho de coelhos e tem o casco como de cágado, parecem um cavalo armado, tem um rabo do mesmo casco comprido, o focinho é como de leitão e tem as pernas baixas, crião-se em covas, sua carne tem o sabor parecido com galinha, esta caça é muito estimada na terra (1980, p. 49).

\footnotetext{
${ }^{187}$ CARDIM, “Tratados da terra e gente do Brasil”, 1980, p. 57.

188 BRANDÃO, “Diálogos das Grandezas do Brasil”, 1943, p. 246.

${ }^{189}$ GANDAVO, “Tratado da Terra do Brasil - História da Província de Santa Cruz”, 1980, p. 102.

190 BRANDÃO, “Diálogos das Grandezas do Brasil”, 1943, p. 251.
} 
Outra interessante descrição é a de um estranho e admirável animal chamado sarigué feita por Simão de Vasconcelos, que é

[...] do tamanho de um cachorro, cabeça de raposa, focinho agudo, dentes, e barba à maneira de gato, as mãos mais curtas que os pés, negro pela maior parte. O que é mais extraordinário nele, é que na parte inferior do ventre, lhe formou a natureza um bolso, a que os índios chamam tambeó, e neste mesmo lhe incluiu os peitos com oito tetas. Aqui que concebe, gera, forma e cria os filhos, enquanto por si não são capazes de buscar de comer (1977, v. 1, p. 165).

Curiosamente, encontra-se semelhante descrição realizada por Ambrósio Fernandes Brandão, ao tratar um animal chamado mocó ou guaqui, que tem um bolso na barriga, em que abrigam os filhos após o nascimento, "quando caminham, os levam ali dentro metidos, e estando parados, os soltam para que pastem e comam pelo campo" (1943, p. 255).

Outro tema recorrente entre os cronistas é o da enorme quantidade de animais ferozes e venenosos que há pelo Brasil. Relata-nos Pero de Magalhães Gandavo, que, o Brasil por ser imenso e pouco habitado, cheio de altíssimos arvoredos e espessos matos, não é de espantar que haja nele muitos animais ferozes e venenosos, visto que, mesmo, que os homens os matem sempre, não acabam nunca, ainda mais nesta Província, "onde os climas e qualidades dos ares terrestres, nam são menos dispostos para os gerarem, do que a terra em si, pelos muitos matos que digo, acomodada pera os criar” (1980, p. 102), que geram-se, com a influência do sol, muitos animais peçonhentos, dos quais são encontrados uma infinidade por toda a terra. ${ }^{191}$

Vemos aqui, que ainda vigia nessa época, a concepção aristotélica da geração espontânea, que só viria a ser derrubada completamente no século XIX, com as experiências de Pasteur, que provaram que vida só se gera a partir de vida pré-existente.

Porém, com tamanha imundície e variedade de animais que pela terra espalhou a natureza, os portugueses passaram a conhecer a terra e a entender o proveito da criação, pois, nesta terra, os animais são todos bravos por natureza, sendo alguns tão estranhos que nunca foram vistos em outras partes. A princípio, Gandavo interpreta a variedade de tão imundos animais, como algo repugnante, o que entraria em contradição com o bom e o belo Criador. Todavia, à medida que estes seres foram mais bem compreendidos, vêm a desfazer tão imprópria interpretação, passando a enxergar o proveito de sua criação.

${ }^{191}$ GANDAVO, “Tratado da Terra do Brasil - História da Província de Santa Cruz”, 1980, p. 109-110. 
Fernão Cardim ao tratar dos animais peçonhentos, nos diz que "parece que este clima influe peçonha, assi pelas infinitas cobras que ha, como pelos muitos Alacrás, aranhas e outros animaes immundos" (1980, p. 31). E, também, Gabriel Soares de Sousa, nos diz que na Bahia se cria muita diversidade de aranhas tão estranhas que convém declarar a natureza de algumas, como a nhanduçu, "as quais são tamanhas como grandes caranguejos, e muito cabeludas e peçonhentas; remetem à gente de salto e têm os dentes tamanhos como ratos, cujas mordeduras são mui perigosas” (1987, p. 268).

Ao tratar da diversidade das rãs e sapos que há no Brasil, Gabriel Soares tece um curioso comentário: "nem tudo é a vontade dos homens, ordenou Deus que entre tantas coisas proveitosas para o serviço dele, como fez na Bahia, houvesse algumas imundícias que os enfadassem muito, para que não cuidassem que estavam em outro paraíso terreal” (1987, p. 265). É a primeira vez que este cronista inclui Deus como ordenador das coisas, não obstante com uma concepção estranha, já que ordenou que entre tantas coisas proveitosas para os homens, houvesse algumas imundícies que os enfadassem muito, ou seja, algo de ignóbil é criado, para que se diferencie da perfeição do paraíso. Isto é, Gabriel Soares busca enfraquecer uma ética secularizante que a Idade Moderna vê crescer, em oposição ao teocentrismo. Ele quer mostrar que a verdadeira felicidade só poderia estar na outra vida, para os que a merecessem.

Outro tema que aparece nas interpretações dos cronistas é a fantasiosa descrição de alguns animais ou fatos estranhos ao seu imaginário, como nos afirma Gandavo, que há no Brasil muitas cobras peçonhentas, dentre elas existe as hebijaras que,

[...] tem duas bocas huma na cabeça outra no rabo, mordem com ambas [...]. Ha outra qualidade dellas que não tem dentes nem mordem. Estas não são peçonhentas nem tam pouco muito grandes, chamão-lhes japaranas. Tambem affirmão alguns homens que virão serpentes nesta terra com azas mui grandes e espantosas, mas achão-se raramente (1980, p. 60).

Do mesmo modo, Frei Vicente do Salvador nos relata numa fantasiosa descrição que há cobras de duas cabeças a morder tanto com o rabo, como com a cabeça. ${ }^{192}$

Comenta Brandônio que, entre as cobras, viu umas tão grandes e estranhas, que, “depois de mortas e comidas dos bichos, tornam a renascer como a Phenix, formando

${ }^{192}$ SALVADOR, "História do Brasil, 1500-1627”, 1982, p. 72. 
novamente sobre o espinhaço carne e espírito" (BRANDÃO, 1943, p. 263). Também nos afirma Gabriel Soares de Sousa, ao tratar de um bicho estranho que se cria na Bahia, a que os índios chamam buijeja, que ele é do tamanho de uma lagarta de couve e, ao ser de noite, parece uma candeia acesa "tem este bicho uma natureza tão estranha que parece encantamento, e tomando-o na mão parece um rubi, mui resplandecente, e se o fazem em pedaços, se torna logo a juntar e a andar como dantes" (1987, p. 267).

Segundo Pero de Magalhães Gandavo, há no Brasil muitos bugios de variadas castas, mas há uns pretos que são muito bravos de natureza, tem a barba como homem e, ao serem alvejados pelos índios, retiram as flechas do corpo e tornam a arremessá-las a quem lhes atirou. ${ }^{193}$ A mesma história nos conta Fernão Cardim, ao tratar dos bugios, especialmente do aquigquig, que são muito grandes, pretos e tem grande barba debaixo do queixo. Destes, às vezes, nasce um macho ruivo que dizem que é seu rei, há também pardos e amarelos; dizem os naturais da terra que, quando alguém lhes atira uma flecha, tornam a atirá-la à pessoa que a jogou. ${ }^{194}$

Brandônio comenta que também há nesta terra um estranho animal chamado preguiça, pelos portugueses, e ahum, pelo gentio natural. É do tamanho de um cachorro, tem a cor parda e preta, e as mãos e pés com dedos muito distintos e acompanhados de grandíssimas e agudas unhas. É bicho dotado por natureza de grande preguiça, que ao subir em uma pequena árvore gasta pelo menos dois dias. ${ }^{195}$

A fauna, encontrada tanto no litoral quanto nas matas, apresenta um vistoso colorido, principalmente as borboletas e as aves, que são encontradas em grande quantidade e possuem variadas e notórias belezas. De uma maneira geral, os cronistas e viajantes nos relatam, ao tratar especificamente das aves, que há uma enorme quantidade delas por esta terra, de variadas cores e muito belas.

Relata Gandavo que a maior beleza que se apresenta à vista humana é a grande variedade das alegres cores das muitas aves. Há muitos papagaios de diversas castas e muito formosos, sendo que os mais raros de todos são uns grandes, maiores que dos Açores a que chamam Anapurus. Há também uns pequeninos papagaios falantes chamados tuyns “aos quaes vestio a natureza de uma fina penna verde muito fina sem outra nenhuma

\footnotetext{
${ }^{193}$ GANDAVO, “Tratado da Terra do Brasil - História da Província de Santa Cruz”, 1980, p. 109.

${ }^{194}$ CARDIM, "Tratados da terra e gente do Brasil", 1980, p. 28.

195 BRANDÃO, "Diálogos das Grandezas do Brasil”, 1943, p. 257.
} 
mistura, e tem o bico e as pernas brancas, e hum rabo muito comprido. Estes também falam, e sam muito fermosos” (1980, p. 113). Há umas notáveis aves marinhas chamadas Goarás, cuja primeira pena de que a natureza as veste é inteira branca, mas após dois anos nasce outra de cor parda e, após o mesmo tempo, torna a mudar, e fica vestida de uma pena muito preta distinta de toda outra cor. ${ }^{196}$

Segundo Fernão Cardim, assim como este clima influi peçonha, também parece influir formosuras aos pássaros, pois, toda a terra cheia de bosques e arvoredos é habitada por pássaros de todas as cores. ${ }^{197}$ Há várias espécies de passarinhos chamados guainumbig, conhecidos como pássaros ressuscitados nas Antilhas:

[...] seis mezes dorme e seis mezes vive; he o mais fino pássaro que se póde imaginar, tem um barrete sobre sua cabeça, a qual se não pode dar cor propria, porque de qualquer parte a tomão mostra vermelho, verde, preto e mais cores todas muito finas, e resplandescentes, e o papo he tão formoso que de qualquer parte que o tomão, mostra todas as cores principalmente hum amarello mais fino que ouro. $\mathrm{O}$ corpo he pardo, tem o bico muito comprido, e a lingoa de dous comprimentos do bico; são muito ligeiros no voar, e quando voão fazem hum estrondo como abelhas, e mais parecem abelhas na ligeireza que passaros, porque sempre comem de vôo sem pousar na árvore; asi como abelhas andam chupando o mel das flores; tem dous principios de sua geração; uns se gerão de ovos como outros passaros, outros de borboletas, e he cousa para ver, huma borboleta começar-se a converter neste passarinho, porque juntamente he borboleta e passaro, e assi se vae convertendo até ficar neste formosissomo passarinho; cousa maravilhosa, e ignota aos philsophos, pois hum vivente sem corrupção se converte noutro (1980, p. 33).

Simão de Vasconcelos, ao se referir às aves do Brasil, nos diz que em todo o universo não viu tantas espécies e nem mais formosas, que parecem as mesmas dos primitivos ares, criadas no Paraíso da terra. Ele nos notifica que há um pássaro chamado pica-flor, que nasce da borboleta, que só naquele primeiro Céu terreno podiam pintar-se tão finas cores,

Um só exemplo não posso deixar de referir que mostra muito a fecundidade, e variedade das aves destes ares: e é que de um passarinho se contam nove espécies, diversas todas, a qual mais galante, e enfeitada da natureza; chamam a este passarinho em geral os naturais da terra goanhambig: em particular a umas espécies, chamam goaraciaba, que quer dizer raio do sol; a outras quoaraciaba, que quer dizer cabelo do sol e a outras põem outros nomes,

\footnotetext{
196 GANDAVO, “Tratado da Terra do Brasil - História da Província de Santa Cruz”, 1980, p. 113.

${ }^{197}$ CARDIM, "Tratados da terra e gente do Brasil", 1980, p. 32.
} 
segundo o modo de sua formosura, que é tão vária, e aprazível, que não poderá arremedá-la o mais destro pintor com as mais finas tintas: rouba o verde do colo do pavão, o amarelo do pintassilgo, o louro do papagaio, e o vermelho do guará, ou tié, [...]. Chamam-lhe os portugueses pica-flor. É ave mui pequena: quatro delas não fazem o corpo de um só pintassilgo: tem cabeça redonda, bico comprido, vive somente do orvalho das flores, por cuja falta, sendo tomada viva, morre logo. Seu vôo é ligeiríssimo; quase não se enxerga no ar, e voando pasce nas flores. Esta avezinha suposto, que fomenta seus ovos, e deles nasce, é cousa certa, que é produzida muitas vezes de borboletas. Sou testemunha, que vi com meus olhos uma delas meia ave, e meia borboleta, ir-se aperfeiçoando debaixo da folha de uma latada, até tomar vigor, e voar (1977, v. 1, p. 163).

No Brasil, segundo Sérgio Buarque, só aos poucos parece ir perdendo terreno aquele realismo fantástico repousado nos escritos dos primeiros cronistas. Abrem exceção, mesmo antes de Simão de Vasconcelos, algumas biografias, como a de Anchieta, mas as concessões ao milagroso não são novidade nem escândalo, num gênero que por definição se abre ao sobrenatural, porém,

[...] já em Vasconcelos, porém, essa imaginação piedosa irá complicar-se através da fascinação mirífica dos segredos e "curiosidades" da terra. E a tanto vai a fascinação, que não se contenta ele apenas com o invocar testemunhos alheios, mas procura sustentar-se, em um ou outro caso, nas próprias e delirantes visões. Assim é que trata de abonar com seu depoimento pessoal os mais extravagantes fenômenos, como o é a metamorfose de uns bichinhos brancos, nascidos à tona da água, que julga ver, com seus olhos, fazerem-se mosquitos, estes mudarem-se em lagartixas, estas tornarem-se borboletas e finalmente as borboletas transformarem-se em colibris. Ainda aqui é preciso dizer que os olhos do cronista se deixaram simplesmente iludir pelo prestígio de uma opinião corrente e já tradicional entre os índios da costa, que costumavam dar os colibris por mensageiros de outra vida. Apesar de oposta à lei da natureza e ainda à velha doutrina de que nenhum vivente se pode converter em outro sem corrupção, a mesma crença, já registrada, ainda que mais discretamente, por Anchieta e Cardim, teria em seu favor manifestas aparências. Sabe-se, com efeito, de certas borboletas do Brasil, que são muitas vezes vistas a esvoaçar junto aos beija-flores em busca do mesmo pasto (HOLANDA, 1966, p. 135).

Ambrósio Fernandes Brandão nos relata através do interlocutor Brandônio, que as aves encontradas por toda esta terra são inumeráveis, por ser o clima disposto para sua criação. E que, além das aves domésticas, é encontrada, pelos bosques e campos, grande quantidade de galinhas silvestres e uns pássaros de cor preta tristonha, chamados anuns, que são constituídos de uma estranha qualidade, porque, além do seu canto se assemelhar a 
choro, este pássaro não tem nenhum sangue pelo corpo. Mas, Alviano acha estranha a natureza desse pássaro, já que nunca ouviu dizer de outro que carecesse de sangue. ${ }^{198}$

Na obra "Caramuru", Santa Rita Durão nos descreve os exemplares da fauna existentes nesta terra do Brasil,

[...] nutre a vasta região raros viventes

Em número sem conto e em natureza/

Dos nossos animais tão diferentes, Que enchem a vista da maior surpresa.

[...] Negou às aves do ar a natureza

Na maior parte a música harmonia;

Mas compensa-se a vista na beleza

Do que pode faltar na melodia:

A pena do tucano mais se preza,

Que feita de ouro fino se diria,

Os guarazes pelo ostro tão luzidos,

Que parecem de púrpura vestidos (2006, p. 225 e 228).

Gandavo descreve alguns peixes notáveis que há nesta partes, como as baleias de onde provém o âmbar, que muitos dizem ser esterco de baleias e, outros, que é o seu esperma. Mas, o que se tem por certo, é que este licor nasce em algumas partes do fundo do mar, que a natureza acha disposta para criá-lo. Ele é o manjar das baleias que chega às praias. Afirma-se que os naturais da terra comem tanto deste âmbar até se embebedarem. ${ }^{199}$

Fernão Cardim ao se referir aos peixes peçonhentos, descreve o caramuru, que são peixes como as moreias de Portugal; eles têm estranha dentadura e há muitos homens aleijados, porque suas mordidas lhes apodrecem as mãos ou pernas: "tem por todo o corpo muitos espinhos, e dizem os naturaes que têm ajuntamento com as cobras, porque os acham muitas vezes com elas enroscados, e nas praias esperando as ditas moreas" (1980, p. 49). Cardim também afirma que não faltam rãs nos rios, fontes e lagoas, e são de muitas espécies, especialmente do guararigeig que,

[...] he cousa espantosa o medo que della têm os Indios naturaes, porque só de a ouvirem, morrem, e por mais que lhes preguem não têm outro remédio senão deixar-se morrer, tão grande he a imaginação, e apprehensão que tomão de a ouvir cantar; e qualquer Índio que a ouve morre, porque dizem que deita de si hum resplandor como relâmpago (1980, p. 57).

\footnotetext{
198 BRANDÃO, “Diálogos das Grandezas do Brasil”, 1943, p. 227.

199 GANDAVO, "Tratado da Terra do Brasil - História da Província de Santa Cruz”, 1980, p. 116-118.
} 
Gabriel Soares de Sousa ao discorrer sobre os peixes que se criam tanto no mar quanto nos rios da Bahia, trata de um peixe não conhecido, encontrado na costa, em 1584, num local chamado Tapoã, em que os moradores disseram,

[...] vir um grande vulto do mar fazendo grande marulho de diante após o peixe miúdo que lhe vinha fugindo para a terra, até dar em seco; e como vinha com muita força, varou em terra pela praia, de onde se não pôde tornar ao mar por vazar a maré e lhe faltar a água para nadar; ao que acudiram os vizinhos daquela comarca a desfazer este peixe, que se desfaz todo, em azeite, como faz a baleia; o qual tinha trinta e sete palmos de comprido, e não tinha escama, mas couro muito grosso e gordo como toucinho, de cor verdoenga; o qual peixe era tão alto e grosso que tolhia a vista do mar, a quem se punha detrás dele; cuja cabeça era grandíssima, e tinha por natureza um só olho no meio da frontaria do rosto; as espinhas e ossos eram verdoengas; ao qual peixe não soube ninguém o nome, por não haver entre os índios nem portugueses quem soubesse dizer que visse nem ouvisse que o mar lançasse outro peixe como este fora, de que se admiraram muito (1987, p. 276).

Brandônio comenta que se acham diferentes castas de caranguejos, que são verdadeiro sustento dos pobres, dos índios naturais e escravos da Guiné, pela abundância que há deles; há diferentes castas como uçá, siri, goajá, guoazaranha e aratu que se utiliza contra peçonha. Também se acham uns de outra qualidade, chamados garauçá e, sobretudo, os guanhamús, cuja natureza causa espanto. ${ }^{200}$

Para encerrarmos este tópico, aproveitamos a descrição da fauna do Brasil realizada por Simão de Vasconcelos na qual apresenta uma natureza que é um paraíso terreno criado por Deus, exuberante e farta, com imensa variedade de animais aquáticos, terrestres e aviários. Deste modo, notifica este cronista sobre as bondades da terra do Brasil, que são as mesmas com que Deus a criou em sua primeira formação.

${ }^{200}$ BRANDÃO, "Diálogos das Grandezas do Brasil”, 1943, p. 245. 


\section{6 - O homem}

Em princípio pode soar estranho, numa pesquisa referente à análise das representações da natureza, haver um capítulo que trata do homem, uma vez que paradoxalmente ele está inserido no limiar entre cultura e natureza; no entanto, em vários relatos dos cronistas e viajantes em análise, eles os denominam os "naturais da terra", justamente porque viviam em plena natureza ou, como os denomina Capistrano de Abreu, eram os "filhos da natureza" (1988, p. 190).

Segundo Afonso Arinos de Melo Franco, em sua obra "O Índio Brasileiro e a Revolução Francesa", quando as caravelas de Cabral chegaram às praias de Vera Cruz, "o espanto maior dos nautas não foi causado pela estranheza ou formosura da terra, mas pelo fato de seus habitantes serem homens, como outros quaisquer, criaturas normais, iguais às das geografias conhecidas, seres criados à imagem de Deus” (2000, p. 29).

O primeiro relato do homem da terra foi realizado por Pero Vaz de Caminha, em 1500, na região de Porto Seguro. Ele nos descreve que andavam pela praia aproximadamente vinte homens pardos, todos nus, com arcos e flechas, e sem nenhuma coisa que lhes cobrisse suas vergonhas, com tanta inocência como têm em mostrar o rosto. E, logo após, acrescenta que o capitão recebeu alguns índios com muito prazer e festa, e eles eram pardos, meio avermelhados, de bons rostos e narizes bem feitos. ${ }^{201}$

Também foi descrita uma índia toda pintada e que "acjma daquela timtura aqual çerto era tã bem feita e tam rredomda e sua vergonha que ela nõ tijnha tam graçiossa que amujtas molheres de nossa trra vendolhe taaes feições fezera vergonha por nom teerem asua comeela" (CAMINHA, 1968, p. 20). Para Afonso Arinos, a comparação que Caminha faz dos índios em relação aos europeus se resume na ideia de que "o ser que vive à lei da natureza é sempre mais perfeito do que o deformado pela civilização. É, pois, a velha teoria da bondade natural que se expressa sob esta forma" (FRANCO, 2000, p. 50).

Deste modo, fica evidente, através do relato de Pero Vaz de Caminha, que o primeiro contato entre os portugueses e os naturais da terra foi amistoso, que estes estranhos homens eram formosos e viviam num estado de completa inocência: "a innocencia desta gente é tal que a de Adão não seria mais quanta em vergonha"

${ }^{201}$ CAMINHA, “Carta de Pero Vaz de Caminha”, 1968, p. 08-12. 
(CAMINHA apud ABREU, 1999, p. 98), fato corroborado por Gandavo quando nos relata que estes naturais da terra "vivem livres de toda a cobiça e desejo desordenado de riquezas" (1980, p. 128) o que, segundo ele, justificaria o fato de não obterem fazendas nem estados pois, todos eles são iguais e ainda vivem conforme a lei da natureza.

Em sua, "Carta", o Piloto Anônimo nos descreve o selvagem e a terra brasileira. Para ele, os homens e as mulheres eram formosos, andavam nus inocentemente, "pescavam, caçavam dormiam suspensos em redes, cercavam-se de aves lindas e multicores. No meio do clima doce, viviam em pleno estado natural" (FRANCO, 2000, p. 50). Lembramos que, devido a sua rápida divulgação na Europa, em 1507, esta narrativa teve maior importância do que a Carta de Caminha, que só posteriormente seria divulgada.

Uma diferente interpretação foi realizada por Simão de Vasconcelos, já no século XVII, relativa aos primeiros contatos entre os portugueses e os naturais da terra, no momento do descobrimento do Brasil, em que, segundo ele, a armada atracou em um lugar chamado Porto Seguro para descansar da viagem e experimentar terra tão formosa; e que Cabral mandou que fossem investigar a natureza da terra, ao retornarem disseram que era “terra fértil, amena, vestida de erva, e arvoredo, e cortada de rios; e que vira andar junto às praias uns homens nus, que tiravam de vermelhos, cabelo corredio, com arco, e flechas nas mãos. [...] vinham a vê-los com espanto, como a monstros da natureza" (1977, v. 1, p. 54).

Por outro lado, a ideia da corrupção deste nosso mundo e da natureza, em consequiência do Pecado e da Queda, acha-se implantada em todo o sentimento e pensamento cristãos, e deita claramente suas raízes nas Sagradas Escrituras. E ainda, para recorrer ao Novo Testamento, onde está dito que toda a criação, e não somente a espécie humana, "geme e padece até hoje" por culpa do primeiro homem. O perfeito acordo entre todas as criaturas, a feliz ignorância do bem e do mal, são elementos constitutivos da condição primeira do homem, que há de ser abolida com o Pecado e a Queda. Sobre esse núcleo inicial, que pertence ao Gênese, ampliado, em seguida, de traços oriundos do Apocalipse e, depois, de novos e sucessivos atributos tomados geralmente às crenças do paganismo, irão engastar-se pouco a pouco os juízos interpretativos dos padres da Igreja e dos teólogos, para formar, finalmente, a ideia do Paraíso Terrestre. ${ }^{202}$

${ }^{202}$ HOLANDA, "Visão do Paraíso", 1996, p. 187. 
O esteio mais poderoso dessa doutrina foi sempre Agostinho, cuja autoridade não cede senão em muito pouco a da própria Sagrada Escritura. Para Agostinho somente Adão possuíra a liberdade de não pecar, ao passo que, em consequiência da queda dos primeiros pais, toda humanidade decai conjuntamente. Também Tomás de Aquino apela para o fato de que ele reconhecera em suas obras, a livre escolha da graça divina, em que havia degraus muito elevados aos eleitos e degraus mais baixos para os condenados. ${ }^{203}$

Estas duas tendências interpretativas, ora a bondade, ora a maldade do natural da terra, permeará todo o período colonial brasileiro. Assim como o descobrimento da América veio fixar geograficamente uma série de monstros humanos, veio, também, dar pátria aos nossos naturais, por serem homens belos e felizes, que viviam numa espécie de Idade de Ouro, conforme a lei da natureza, e cuja existência era admirada. Aos cronistas desta última tendência, o índio aparecia não mais como um monstro, mas, ao contrário, como um homem bem constituído física e moralmente, que desfrutava de uma existência idílica, no meio de uma natureza acolhedora. ${ }^{204}$

No entanto, Simão de Vasconcelos não nos explica o que ele quis dizer ao chamar os naturais de "monstros da natureza", isto é, se alude à temática fantasiosa proveniente da Idade Média, ou a outra coisa. Também Pero Vaz de Caminha nos relata na "Carta" que, ao mesmo tempo em que os naturais da terra amansam, de repente se esquivam, como pardais e, assim, parece ser gente bestial e de pouco saber. Devido a isso são tão esquivos, mas que, no entanto, eles andam muito saudáveis, limpos e formosos. ${ }^{205}$

Efetivamente, o conceito de bondade natural do homem não data, apenas, do humanismo filosófico do Renascimento nem do individualismo enciclopédico do século XVIII. Trata-se de uma teoria que provém da Antiguidade, sendo que no pensamento ocidental a encontramos nas obras dos estoicos e dos epicuristas gregos. No tempo de Roma, Sêneca afirma um estado natural, no qual o homem era inocente e feliz. Esta ideia será repetida na Idade Média e no Renascimento, "pela convicção de que o homem é naturalmente bom, através das leituras das narrativas de viagens, fantásticas ou verídicas" (FRANCO, 2000, p. 45).

\footnotetext{
${ }^{203}$ MILLER, “Os Jesuítas - seus segredos e seu poder”, 1932, p. 116-117.

${ }^{204}$ FRANCO, "O Índio e a Revolução Francesa”, 2000, p. 43-44.

205 CAMINHA, “A Carta de Pero Vaz de Caminha”, 1968, p. 34.
} 
Diante do relato dos cronistas e viajantes, fica claro que, à medida que houve maior contato entre estas diferentes culturas, os naturais da terra foram perdendo aquelas primeiras impressões paradisíacas de completa inocência.

Ao se referir aos hábitos indígenas, Ambrósio Fernandes Brandão nos diz, através de Brandônio, que antigamente e ainda nos dias em que vive, no sertão, os naturais andavam e andam todos despidos. Mas que, agora, o gentio que habita entre nós anda coberto, costume que introduziram custosamente entre eles os Padres da Companhia, pois não havia quem o fizesse separar de sua natureza, a qual os incitava a andarem nus. ${ }^{206}$

Aquela tênue amizade propiciada pelos primeiros contatos foi-se transformando, a partir da instauração do projeto colonizador português, e assumiu outras interpretações, como podemos averiguar na constatação de Pero de Magalhães Gandavo, segundo o qual:

[...] são estes indios mui deshumanos e crueis, não se movem a nenhuma piedade: vivem como brutos animaes sem ordem nem concertos de homens, são mui deshonestos e dados á sensualidade e entregão-se aos vícios como se nelles não houvera rezão de humanos, ainda que todavia sempre têm resguardo os machos e as fêmeas em seu ajuntamento, e mostrão ter nisto alguma vergonha. Todos comem carne humana, e têm na pela melhor iguaria de quantas pode haver: não de seus amigos com quem elles têm paz se não dos contrarios (1980, p. 57).

O mesmo Gandavo nos relata, na "História da Província de Santa Cruz", que os índios Tapuias que vivem junto a um rio do Maranhão, além de também não comerem carne de nenhum contrário, são inimigos daqueles que a costumam comer, mas, apesar disso, eles tem outro rito muito mais diabólico contra a natureza, pois, quando algum está doente, com risco de morrer: os pais, irmãos ou parentes, o acabam de matar, usando-se de piedade, para livrá-lo do sofrimento vagaroso da morte. ${ }^{207}$

Cabral mandou, na caravela de Gaspar de Lemos, um dos índios da terra descoberta, e que, segundo Simão de Vasconcelos, este nosso selvagem

[...] foi recebido em Portugal com alegria do Rei e do Reino. Não se fartavam os grandes e pequenos de ver e ouvir o gesto, a falla, os meneios daquelle novo indivíduo da geração humana. Huns o vinhão a ter por hum

\footnotetext{
206 BRANDÃO, “Diálogos das Grandezas do Brasil”, 1943, p. 274.

${ }^{207}$ GANDAVO, “Tratado da Terra do Brasil - História da Província de Santa Cruz”, 1980, p. 141.
} 
Semicargo, outros por um Fauno, ou por alguns daquelles monstros antiguos, entre poetas celebrados (Apud FRANCO, 2000, p. 75-76).

No entanto, apesar desta dúbia interpretação que perpassa as obras dos cronistas e viajantes, a visão da bondade do natural da terra foi adquirindo uma importância maior do que a maldade desta "besta selvagem", conforme foi descrito. Este mito do bom selvagem foi uma representação contrária à do homem-monstro da Idade Média. Os descobrimentos geográficos deram grande impulso ao humanismo individualista, em que o homem volta às bases filosóficas e políticas da Antiguidade greco-romana, que prosperamente renascia, contra o coletivismo da Idade Média. ${ }^{208}$

Diante dos relatos destes cronistas e viajantes disseminam-se inúmeras interpretações, muitas vezes incoerentes com o verdadeiro modo de vida dos naturais da terra, como podemos ver nestas palavras expressas por Gandavo:

A língua deste gentio toda pela costa he, huma: carece das letras, não se acha nella $\mathrm{F}$, nem $\mathrm{L}$, nem $\mathrm{R}$, cousa digna de espanto, porque assi não têm Fé, nem Lei, nem Rei; e desta maneira vivem sem Justiça e desordenadamente. Estes indios andão nús, sem cobertura alguma, [...] trazem descoberto quanto a natureza lhes deu. [...] Não adorão cousa alguma nem têm pera si que ha na outra vida gloria pera os bons, e pena pera os maos, tudo cuidão que se acaba nesta e que as almas fenecem com os corpos, e assi vivem bestialmente sem ter conta, nem peso, nem medida (1980, p. 52).

Assim como Gabriel Soares de Sousa, ao tratar do modo de vida e da linguagem dos tupinambás, relata que, apesar de eles viverem divididos e se inimizarem uns com os outros, todos falam uma língua que é quase geral pela costa do Brasil e todos têm os mesmos costumes em seu modo de viver. Não adoram a coisa alguma, nem têm nenhum conhecimento da verdade e são mais bárbaros que todos os seres que Deus criou. ${ }^{209}$ Neste fragmento, aparece a ideia de que os índios eram criaturas geradas pela natureza, mas que, segundo Gabriel Soares, são apresentadas agora como criação divina. Deste modo, pode-se afirmar que, para os cronistas, Deus é o criador das coisas e da natureza. Como segundo Simão de Vasconcelos, na "Crônica da Companhia de Jesus",

\footnotetext{
${ }^{208}$ FRANCO, “O Índio e a Revolução Francesa”, 2000, p. 46-47.

${ }^{209}$ SOUSA, “Tratado Descritivo do Brasil", 1987, p. 302.
} 
São incompreensíveis os juízos de Deus: 6691 anos havia, que aquela sua imensa bondade, e onipotência infinita tirara do nada ao ser esta máquina terrena, que vemos igualmente umas partes, e outras, [...] igualmente formadas em um globo, e assentadas em um mesmo centro, com a mesma formosura de montes, campos, rios, plantas e animais, para perfeita habitação dos homens. E contudo não sei com que destino lhe caiu mais em graça ao Criador uma parte desta mesma terra, que outra, porque aquela que de três partes, Europa, África e Ásia, compõe uma só, escolheu Deus para criar o homem, formar Paraíso terreno autorizá-la com Patriarcas, cabeça dos viventes racionais; e o que mais é, com sua divina presença feita humana, luz verdadeira de nossa bemaventurança. Porém a outra parte da terra, outro mundo igual, não menos aprazível, da qual dissera o mesmo Criador, que era muito boa; deixou-a ficar em esquecimento, sem Paraíso, sem Patriarcas, sem sua divina presença humanada: sem luz da Fé, e salvação; até que depois decorridos os séculos de 6691 anos, deu ordem como aparecesse este novo, e encoberto mundo (1977, v.1, p. 50).

Simão de Vasconcelos nos declara que, ao ser considerada com atenção a liberdade com que o Autor do universo repartiu seus bens naturais com esta terra do Brasil, a fertilidade de seus solos, a frescura de suas campinas, a verdura de seus montes, o ameno de seus bosques, a riqueza de seus tesouros, e a delícia de seus ares e climas, sem dúvida que julgaria que, à medida de tão bem adornado palácio, faria o Senhor a escolha dos homens, que o haviam de habitar, qual lá escolheu Adão e Eva à medida do terreal Paraíso, que para eles preparara, mas, aqui tudo sucedeu ao contrário:

Lançará os olhos por esses campos, por essas brenhas, por essas serranias; e verá nelas espécies de gentes inumeráveis, que vivem a modo de feras, e como tais contentes com o tosco das brenhas, e solidão da penedia, desprezando todo o polido dos palácios, cidades, e grandezas de todas as mais partes do mundo (1977, v. 1, p. 97).

Assim, para Simão de Vasconcelos, todas estas nações de gentes que habitam seus sertões são feras selvagens e desumanas, que vivem ao som da natureza; ele reafirma a ideia de que estas nações não seguem fé, nem lei, nem rei, e que lhes foi negado pelo Autor da natureza às letras, F, L e R. Analisa, assim, que seu Deus é seu ventre posto que quem os rege são seu apetite e gosto; "andam em manadas pelos campos de todo nus, assim homens, como mulheres, sem empacho algum da natureza. Vive neles tão apagada a luz da razão, quase como nas mesmas feras" (1977, v. 1, p. 97). Ainda segundo este cronista, muitos dos primeiros povoadores da América consideraram que os índios não eram verdadeiramente homens racionais, nem indivíduos da verdadeira espécie humana, e que, por conseguinte, 
eram incapazes dos sacramentos da Santa Igreja "que podia tomá-los para si, qualquer que os houvesse, e servir-se deles, da mesma maneira que de um camelo, de um cavalo, ou de um boi, ferilos, maltratá-los, matá-los, sem injúria alguma, restituição ou pecado. E o pior é que pôs o interesse dos homens em praxe usual tão desumana opinião" (1977, v. 1, p. 114).

A este lastimável estado socorreu o dominicano Fr. Domingos de Betanços que mandou a Roma um religioso da mesma Ordem, por nome Fr. Domingos da Minaja, a tratar esta causa no Tribunal do Sumo Pontífice no ano de 1537. Este Tribunal determinou com a autoridade do Papa Paulo III, na célebre bula Veritas ipsa, que "os índios da América são homens racionais, da mesma espécie, e natureza de todos os outros; capazes dos Sacramentos da Santa Igreja e por conseguinte livres por natureza, e senhores de suas ações" (VASCONCELOS, 1977, v. 1, p. 115). É diante deste documento que o Papa, “apoiado nas ideias que circulavam na Europa sobre a bondade natural dos nossos índios, declara que eles são verdadeiros homens e não simples bestas de carga, e, portanto, capazes de acudir ao chamado de Cristo" (FRANCO, 2000, p. 54). Ainda segundo Vasconcelos,

[...] quando viam aqueles primeiros portugueses um índio Tapuia, um corpo nu, uns couros, e cabelos tostados pelas injúrias do tempo, um habitador das brenhas, companheiro das feras, tragador da gente humana, armador de ciladas; um selvagem enfim cruel, desumano e comedor de seus próprios filhos: sem Deus, sem lei, sem Rei, sem pátria, sem república, sem razão: não era muito que duvidassem, se era antes bruto posto em pé, ou racional em carne humana. [..] sabemos que seus progenitores foram homens racionais, em cuja geração é cousa certa não nega o Autor da Natureza a infusão de alma racional (1977, v. 1, p. 117 e 119).

De acordo com Afonso Arinos, na primeira metade do século XVII, a noção do selvagem cruel e monstruoso havia sido suplantada pela ideia do bom selvagem, uma vez que eram gentes que desfrutavam uma verdadeira Idade de Ouro. Esta velha concepção interpretativa do homem natural passara do plano especulativo, em que se situava desde a Antiguidade, para o da experiência vivida, graças aos escritos dos cronistas e viajantes. ${ }^{210}$ Da segunda metade do século XVII em diante, o selvagem americano já começa a ser considerado menos como objeto de curiosidade do que como modelo.

\footnotetext{
${ }^{210}$ FRANCO, "O Índio e a Revolução Francesa”, 2000, p. 63.
} 


\section{Conclusão}

Ao finalizarmos esta pesquisa, percebemos que aquela antiga concepção de natureza, vinculada à ideia de "nascer", encontrada nas mitologias homérica, hesiódica e órfica, e que sugere a origem, sendo sinônimo de "gênese", continuará presente na visão dos cronistas e viajantes analisados no período colonial brasileiro. Contudo, tal ideia será cristianizada e, no Novo Mundo, a natureza se apresenta segundo Sérgio Buarque de Holanda, "como nos primeiros dias da Criação, tudo aqui era dom de Deus" (1996, p. X).

Deste modo, há uma só natureza, criada por Deus a partir do nada, conforme fundamento judaico-cristão. Pois, se a natureza é uma natureza criada, ela se distancia dos fundamentos oriundos das mitologias: Homérica e Hesiódica, que nos afiançam uma natureza somente ordenada pelos deuses, mas jamais criada por eles. Não obstante, apesar da exclusão destas mitologias na fundamentação da concepção judaico-cristã da natureza ex nihilo, não implica que não houve influência dessas mitologias nas concepções da Natureza nas obras dos Cronistas e Viajantes do Brasil Colonial.

Podemos verificar certas influências, como nos relatos de Bento Teixeira na obra "Prosopopéia" em que a visão cristã do Deus único se funde a antigos construtos mitológicos: "as Delphicas irmãs, chamar não quero, que tal invocação, he vão estudo, Aquelle chamo só, de quem espero, a vida que se espera em fim de tudo" (1969, p. 121) ou quando paradoxalmente a esta citação ele diz ser "Oceano pay de mor idade" (1969, p. 125), referindo-se a fundamentos Homéricos.

Pode-se também constatar que houve influência da mitologia Órfico-pitagórica, que participou do construto filosófico-teológico cristão, sistematizado por Platão e desenvolvido pelos neoplatônicos, principalmente ao adentrar à Idade Média, em que a natureza material é oriunda de uma natureza imaterial e mais bela, que fundamentou a visão da Natureza nas descrições dos Cronistas e Viajantes do Brasil Colonial, que exerceu influência tanto sobre a astrologia quanto sobre a astronomia, temática encontrada nos escritos de Simão de Vasconcelos e de Bento Teixeira.

É importante pontuar que os pensamentos “puros" de Platão e Aristóteles também não concebem a Natureza criada por um Deus, mas, somente ordenada por ele. Também teorizam assim: os estoicos, que não admitiam a ideia de criação, concebiam um Deus 
imanente ao mundo, para eles, Natureza e Deus se identificam, sendo Deus a razão seminal, cuja semente possui em potência todos os eventos futuros do desenvolvimento, orientados para a perfeição, fundamentos encontrados na obra "O Uraguai" de Basílio da Gama; a filosofia pré-socrática, já que a natureza é dominada pela Necessidade, o princípio que inspira essa corrente é de "nihilo nihil in nihilum posse reverti"; e a corrente atomista de Demócrito e Epicuro cujos átomos são incriados e indestrutíveis, que ao alterar somente seus arranjos, podem criar diferentes mundos, ideia do melhor mundo possível recuperada por Leibniz na Idade Moderna que reaparece na obra "Caramuru" de Santa Rita Durão: "Desde a origem da imensa eternidade, que tudo sem princípio ordena e rege, devemos presumir da Divindade que onde o ótimo encontra, em tudo o elege: e sendo em nós tão grande a iniquidade, não temos cousa que a qualquer se inveje, onde se os mais possíveis vendo fores, nós fomos os eleitos por melhores" (DURÃO, 2005, p. 154).

Contudo, segundo Sérgio Buarque, a ideia predominante no Novo Mundo, é de que,

[...] do outro lado do Mar Oceano se acharia, se não o verdadeiro Paraíso Terreal, sem dúvida um símile em tudo digno dele, perseguia, com pequenas diferenças, a todos os espíritos. A imagem daquele jardim fixada através dos tempos em formas rígidas, compêndio de concepções bíblicas e idealizações pagãs, não se podia separar da suspeita de que essa miragem devesse ganhar corpo num hemisfério ainda inexplorado, que os descobridores costumavam tingir da cor do sonho. E a suspeita conseguia impor-se até mesmo aos mais discretos e atilados, àqueles cujo espírito se formara no convívio assíduo com os autores da Antiguidade (HOLANDA, 1996, p. 184).

Essa ideia defendida por Sérgio Buarque pode ser observada em Simão de Vasconcelos, para quem as qualidades da terra e do clima, a frescura dos arvoredos, a variedade das plantas, a abundância dos frutos e das ervas medicinais, a diversidade dos animais e mais prodígios da Natureza é obra que o "autor dela enriqueceu este novo mundo: poderíamos fazer comparação ou semelhança, de alguma parte sua, com aquele paraíso da terra, em que Deus Nosso Senhor, como em jardim pôs a nosso primeiro pai Adão" (1977, v. 1, p. 166). Ou, como nos dissera Santa Rita Durão que "um só senhor, que todo o ser governa, que só com dizer seja o fez de nada; que a natureza desde a idade eterna, certa época fixou de ser criada" (2005, p. 27).

No entanto, a filosofia cristã restringe o determinismo natural, reduzindo às leis de uma razão superior a aparente desordem da natureza, que encontramos em toda a Patrística 
e Escolástica na Idade Média, cuja ideia será corroborada tanto pelo Concílio de Trento, quanto pela Companhia de Jesus, que se incumbiu da catequização oficial dos "naturais da terra", a mando da Igreja Católica em quase todo o Período Colonial brasileiro. Assim, a Natureza fundamentada pelo Cristianismo é composta por criaturas cuja existência e ordenação depende essencialmente dos desígnios divinos, que a criou e que pode intervir alterando a ordem "natural" dos fenômenos.

A ideia de Natureza que chega ao Novo Mundo proveniente da teologia judaicocristã é apresentada como um sistema de símbolos, que o homem decaído, por causa do pecado, se engana ao tentar decifrar. É assim que a natureza se converte na chave para descobrir os "hieróglifos" divinos, ideia presente em todo o Período Colonial brasileiro.

Neste período aludido, os escritos de Plínio, o Velho, dominarão os Bestiários da Idade Média, ele se utiliza de um panteísmo sincrético, originário de correntes estoicas e platônicas, que permite um amplo recurso à finalidade de redescobrir a Natureza, que é construída como um conjunto de qualidades exteriorizadas, concebida segundo analogias biológicas e artificialistas, como na doutrina da simpatia e da antipatia, cuja analogia psicológica impõe-se com facilidade a um fato. Há uma fauna e uma flora "quentes" ou "frias" em que todos esses fenômenos estão ocultos na Natureza. ${ }^{211}$

Estas propriedades são utilizadas por Pero de Magalhães Gandavo e Gabriel Soares ao relatarem que o caju serve para se refrescar do calor, porque sua natureza é muito fria, e também criou a natureza no olho do pomo uma castanha de natureza quentíssima. Além do cajueiro, nos aponta Gabriel Soares que muitas outras árvores são constituídas de grandes virtudes, como as mangabeiras, que propiciam boa digestão, cuja natureza é fria, sendo muito boa para os doentes de febres por sua leveza.

Com o passar do tempo, a interpretação religiosa passará a um segundo plano, cedendo lugar ao estudo das próprias coisas. Mas, por maior que seja a diversidade das coisas, há entre elas certas analogias, que concernem às próprias essências dos seres. Há uma transição contínua das correspondências analógicas para as simbólicas impressas pelo próprio Criador, ao se manifestar pela natureza.

Estas correspondências simbólicas nas coisas reaparecem em Pero de Magalhães Gandavo, Gabriel Soares e Fernão Cardim, no que se refere à descrição da flora,

${ }^{211}$ PLÍNIO. "História Natural”, 1995, p. 382-385. 
especificada através da análise da banana, como uma representação da natureza que se estende aos homens como um livro divino, cabendo a eles não só a contemplação da natureza, mas também, a responsabilidade de decifrar os sinais. Também merece destaque em "Caramuru" de Santa Rita Durão a "flor da paixão" do maracujá, que representa as coroas de Cristo.

Também tiveram enorme influência sobre os Viajantes e Cronistas dos séculos XVI, XVII e XVIII, os Tratadistas da Natureza Estrabão e Plínio o Velho, visto que suas ideias da natureza, criadas e transformadas, durante todo o pensamento ocidental puderam fundamentar a Literatura de Viagens que se desenvolvia desde o fim da Idade Média e início do Renascimento até a Idade Moderna. Conforme apresenta Sérgio Buarque,

[...] para os teólogos da Idade Média não representava o Paraíso Terreal apenas um mundo intangível, incorpóreo, perdido no começo dos tempos, nem simplesmente alguma fantasia vagamente piedosa, e sim uma realidade ainda presente em sítio recôndito, mas porventura acessível. Debuxado por numerosos cartógrafos, afincadamente buscado pelos viajantes e peregrinos, pareceu descortinar-se, enfim, aos primeiros contatos dos brancos com o novo continente. Mesmo quando não se mostrou ao alcance de olhos mortais, como pareceu mostrar-se a Cristóvão Colombo, o fato é que esteve continuamente na imaginação de navegadores, exploradores e povoadores do hemisfério ocidental. Denunciam-no as primeiras narrativas de viagem, os primeiros tratados descritivos, onde a todo instante se reitera aquela mesma tópica das visões do Paraíso que, inaugurada desde o IV século num poema latino atribuído, erradamente segundo muitos, a Lactâncio, e mais tarde desenvolvida por Santo Isidoro de Sevilha, alcançara, sem sofrer mudança, notável longevidade (HOLANDA, 1996, p. IX-X).

Fernão Cardim nos relata que "a baia do Rio de Janeiro bem parecia que a pintara o supremo pintor e arquiteto do mundo, era coisa formosíssima e a mais aprazível de todo o Brasil” (1980, p. 20). E, Simão de Vasconcelos mostra-nos as propriedades da natureza brasileira, sendo que a terra do Brasil é "por excelência sempre verde, cheia de ervas e arvoredos, de vários gêneros, entre todas as mais terras do mundo, na conformidade do Texto de sua primeira criação" (1977, p. 145).

Como os Cronistas faziam parte do católico mundo ibérico, sendo que em sua maioria compuseram a Companhia de Jesus, muitas das suas concepções da natureza estão embebidas desta religiosidade, como podemos observar em Santa Rita Durão que há de "florescer nesta pátria de improviso uma imagem do ameno paraíso" (2005, p. 176). 
Segundo Fernando Cristóvão as preocupações com a História Natural que vinham desde Aristóteles e Plínio, o Velho, "vieram aprofundar o conhecimento dos reinos da Natureza, por terem facultado um enquadramento científico às descrições dos viajantes" (1999, p. 33). A naturalidade com que estas tradições foram absorvidas pela Literatura de Viagens evidencia-se no modo como se inseriam nos textos ao descreverem países e regiões, com seus tipos humanos e suas paisagens e com a exuberante flora e variada fauna.

Com efeito, conceitos antigos e medievais estão na base das elaborações teóricas dos viajantes e cronistas, no entanto, a narração-descrição da Literatura de Viagens é tipicamente europeia, não podendo identificar-se as obras da Antiguidade, embora elas se reconheçam na sua continuidade histórica. Os séculos XV e XVI representam uma ruptura com os textos de viagens, participantes de outra mundividência, que também referenciou a ideia de utilidade. Para Gabriel Soares de Sousa a terra do Brasil é muito rica, fato que possibilitaria a formação de um poderoso Império. Ele revigora a atitude que exprime o deslumbramento diante dela e de sua valorização, já iniciada por Pero Vaz de Caminha e seguida por Pero de Magalhães Gandavo. ${ }^{212}$

Ao experienciar a natureza brasileira, numa passagem emblemática, Gandavo atesta que "a natureza ainda reflete o tradicional tema do horto das delícias, mas um horto apresentado, quase sempre, sob o ponto de vista da produção: Gandavo descreve plantas e animais com a preocupação de indicar sua utilização" (2004, p. 23-24). Também Santa Rita Durão dirá que, “... há por todo o Brasil em quantidade madeiras para fábricas tão boas, que trazendo-as ao mar por vastos rios, pode encher toda a Europa de navios" (2005, p. 224).

Mas, aos poucos, novas representações da natureza derrubaram concepções formuladas por aqueles que nunca as tinham visto, pois, se na descrição da natureza do Brasil há encantamento, há também ceticismo. Ideias antigas e medievais já passam a ser vistas com ressalvas pelos escritores quinhentistas e seiscentistas.

Assim, cai por terra a ideia da inexistência do céu em todo o orbe, devido aos testemunhos do astrônomo João Faras, onde são identificadas as estrelas da constelação do Cruzeiro do Sul, confirmando a existência do céu nos antípodas, como também é descrito pelo interlocutor Brandônio nos "Diálogos das Grandezas do Brasil", ao nos relatar que, o

${ }^{212}$ LACOMBE. "Prólogo". In: SOUSA. “Tratado Descritivo do Brasil”, 1987, p. 9. 
que mais espanta é ver que toda esta costa "tem excelentíssimo céu e goza de muito bons ares, sadia e disposta para a conservação da natureza humana” (BRANDÃO, 1943, p. 77).

Para Simão de Vasconcelos, os astros que predominam nesta região do Brasil, são bons e, se não excedem, nada ficam aquém às mais partes do mundo. Porque nesta terra a "formosura e resplendor do sol, lua e estrelas parece estar no mesmo momento da sua primeira criação" (1977, p. 158-159). Esta temática da influência dos astros pode ser averiguada, na obra "Prosopopéia" de Bento Teixeira, em uma descrição do porto de Recife que sofre influência dos astros, a natureza é representada como uma mãe prudente: "Era a parte do Sul, onde a pequena, Ursa, se vé de guardas rodeada, onde o Ceo luminoso, mais serena, tem sua influyção, e temperada. Junto da nova Lusitania ordena, a natureza, mãy bem atentada, hum porto tam quieto, \& tam seguro, que pera as curvas naos serve de muro" (TEYXEYRA, 1969, p. 127), esta ideia é semelhante à encontrada em Plínio o Velho, ao dizer: "salve, mãe de todas as coisas, ó Natureza". ${ }^{213}$

Cai por terra também a ideia da insalubridade dos climas, uma vez que, nos dizeres de Sérgio Buarque de Holanda, "a mesma paisagem amena, a mesma eterna primavera, que os descobridores renascentistas irão buscar nas terras incógnitas do outro lado do Oceano, já tinham empolgado os primeiros autores medievais" (1996, p. 169). Essa ideia que percorre toda a Idade Média participará também dos relatos dos Cronistas e Viajantes, como podemos averiguar na "Carta" de Pero Vaz de Caminha, em que neste Brasil a terra em si é de muito bons ares assim frios e temperados. ${ }^{214}$ Esta ideia pode ser constatada em Santa Rita Durão ao nos relatar que no Brasil "admira o clima doce, o campo ameno e entre o arvoredo imenso, a fértil erva na viçosa extensão do áureo terreno” (2005, p. 195).

E, segundo Ambrósio Fernandes Brandão relata nos "Diálogos das Grandezas do Brasil", através do Brandônio, a amenidade do clima se deve aos "ventos da Guiné”, que são ventos frescos provenientes do mar que predominam na costa, fato que propicia um clima excelente e poucas moléstias ao Brasil. Mas, apesar de predominar este vento, Gandavo nos relata que o vento da terra é muito perigoso e doentio, visto que se tornam inficionados pelas podridões das ervas, matos e alagadiços, de onde se geram com a influência do sol, muitos animais peçonhentos, dos quais são encontrados uma infinidade

\footnotetext{
${ }^{213}$ LENOBLE. "História da ideia de Natureza", 1969, p. 119.

${ }^{214}$ CAMINHA. "A Carta de Pero Vaz de Caminha”, 1968, p. 56.
} 
por toda a terra. ${ }^{215}$ Como podemos constatar, ainda é vigente a ideia da geração espontânea, formulada por Aristóteles, que só viria a ser derrubada completamente no século XIX.

Também, aparece na descrição dos cronistas e viajantes a visão aristotélica de que o conjunto da natureza estaria dividido entre a região sublunar, em que cada um dos elementos teria seu "lugar natural" e a região supralunar, constituída por uma quinta essência. Esta visão é encontrada em Simão de Vasconcelos, ao se referir à segunda região do ar, quando via as nuvens na serra do mar a caminho de São Paulo, pois “... parece uma glória o avultar dos montes e serranias, com tal compostura e altura, que representam formas muito para ver, e sobem, parece, à região segunda do ar, levando consigo os olhos e os corações ao Céu" (1977, p. 60), em consonância com a ideia do estagirita.

Outra questão fundamental se refere à possibilidade de existir vida na chamada zona tórrida, que, segundo os antigos, era inabitável devido ao calor existente, questão que será analisada pela própria experiência dos Cronistas e Viajantes, como Simão de Vasconcelos que nos diz que a Bahia "está em altura de treze graus e meio, entre a linha do equador e o trópico Austral; e, contudo zombam seus naturais da doutrina dos antigos filósofos, que tinham para si que era inabitável esta parte do mundo" (1977, p. 190).

Ou seja, também cai por terra a ideia da inabitabilidade das zonas tropicais assegurada por Ambrósio Fernandes Brandão ao afirmar "que nenhuma parte do mundo é mais sadia e de melhor temperamento do que a terra do Brasil. E é tanto assim que não faltam autores que querem afirmar estar nesta parte situado o paraíso terreal..." (GARCIA, apud BRANDÃO, 1943, p. 128). Deste modo, fica comprovado que o Brasil é habitável, contrariando a teoria da inabitabilidade das zonas tórrida provenientes da Antiguidade.

As experiências mais céticas, comprovadas pelos Cronistas e Viajantes, coexistem com concepções mágicas de uma época ainda não afetada pelas formulações racionalistas e pelo método experimental, que estavam nos seus albores. Só aos poucos parece ir perdendo terreno, no Brasil, aquele realismo fantástico repousado nos escritos dos primeiros cronistas. Em tudo vemos um mundo em transição.

Para os primeiros Cronistas e Viajantes a flora, a fauna e os naturais da Terra, se revestiam do "maravilhoso", porque as plantas, os animais e as pessoas das suas terras de origem eram a medida das coisas, para que então, comparativamente, pudessem descrever o

${ }^{215}$ GANDAVO, "História da Província de Santa Cruz”, 1980, p. 109-10. 
que viam, e tudo o que era diferente obtinha o estatuto de estranho e maravilhoso. Eles proporcionaram-nos imensa contribuição ao descrever a natureza ao nos revelar aspectos de uma fauna e flora inéditas, em "um modo aparente de ver a natureza, que consiste, antes, em ver através e apesar da natureza” (HOLANDA, 1996, p. 230).

Assim, aparece nas interpretações dos cronistas à fantasiosa descrição de alguns animais ou fatos estranhos ao seu imaginário, como nos afirma Brandônio que haviam cobras tão grandes e estranhas que depois de mortas tornam a renascer como a Fênix, fato contestado por Alviano por ser contrário às leis da natureza. ${ }^{216}$ Também, Fernão Cardim ao tratar das aves, nos diz que há uma borboleta que se converte em um passarinho.

Outra representação da Natureza comum aos cronistas e viajantes é a de sua exuberância proporcionada pela fertilidade da terra, pela variedade dos animais e pela beleza da vegetação. Também é peculiar ao Brasil a imensidade de suas águas, onde a natureza se apresenta vigorosa, como afirma Gabriel Soares que esta terra é muito fértil, com bons ares e regada de frescas e frias águas. A fauna brasileira é descrita por eles como sendo abundante e variada, contendo muitos insetos, répteis, aves e peixes. Gandavo, no "Tratado da Terra do Brasil", nos informa que há muitos bichos nesta terra, que será impossível conhecer e escrever tamanha quantidade, porque esta terra é muito vasta e são muitas as qualidades e aparências das criaturas que Deus nela criou. ${ }^{217}$

Se, na Idade Média, o mundo é um simples lugar de passagem, em que a deterioração da Natureza resgatava-se num divino plano de salvação vinculado ao Paraíso, na era dos Descobrimentos, é na própria vida que o homem há de encontrar sua razão de ser, visão esta que impregnará o pensamento renascentista, mas que lentamente se distancia da visão deificada da natureza, configurando assim, conforme Sérgio Buarque de Holanda, em uma "Natureza ativa e criadora, concebida à imagem do homem novo" (1996, p. 188).

\footnotetext{
216 BRANDÃO, “Diálogos das Grandezas do Brasil”, 1943, p. 264.

${ }^{217}$ GANDAVO, "Tratado da Terra do Brasil", 1980, p. 62.
} 


\section{Bibliografia}

ABRANTES, Paulo César Coelho. "Imagens de natureza, imagens de ciência”. Campinas, SP, Papirus: 1998, 247 p.

ABREU, João Capistrano de. “Capítulos de História Colonial”. 7ª edição, revisada, anotada e prefaciada por José Honório Rodrigues. Belo Horizonte: Itatiaia; São Paulo: Editora da Universidade de São Paulo, 1988, 295 p.

. “O descobrimento do Brasil”. São Paulo, Martins Fontes, 1999, 210 p.

ADORNO, Rolena. "Los Debates sobre la Naturaleza del Indio en el Siglo XVI: Textos Y Contextos”. In Revista de Estudos Hispânicos. Porto Rico: Ed. Univ. de Porto Rico, 1992.

AGOSTINHO, Santo. "A Cidade de Deus". Tradução, prefácio, nota biográfica e transcrições de J. Dias Pereira. Volume II (Livro IX a XV), Serviço de Educação Fundação Calouste Gulbenkian, Lisboa, 1993, 819-1442 p.

ANCHIETA, José de. "Minhas cartas - Por José de Anchieta". Extraído do livro Cartas, Correspondência Ativa e Passiva, do padre Hélio Abranches Viotti, S. J., São Paulo: Edições Loyola, 1984, 158 p.

, José de. “Auto de São Lourenço - Teatro de Anchieta”. Tradução do Tupi -

Eduardo de A. Navarro; Tradução do castelhano Júlio C. de A. Pedrosa. São Paulo: Ed. Martin Fontes, 1999.

ANTONIL, André João. "Cultura e opulência do Brasil - por sua droga e minas". Texto confrontado com o da edição de 1711, estudo bibliográfico, por Afonso E. Taunay, nota bibliográfica de Fernando Sales, vocabulário e índices antroponímico, toponímico e de assuntos de Leonardo Arroyo. $2^{\circ}$ ed. São Paulo, Melhoramentos; Brasília, 1976, 239 p. 
ARISTÓTELES. "Metafísica”. In Os Pensadores. Tradução: Vicenzo Cocco e notas de Joaquim de Carvalho. Capítulo 4. Ed. Victor Civita, São Paulo, 1973, 533 p.

- "Física". Introducción, tradución y notas de Guillermo R. de Echandía. Editorial Gredos S.A., Madrid, 1998, 503 p.

. "Metafísica”. Tradução de Leonel Valandro. Editora Globo, Porto Alegre, 1989, 311 p.

ARTIGAS, Mariano. "Filosofia da Natureza”. Tradução de José E. de Oliveira e Silva. São Paulo: Instituto Brasileiro de Filosofia e Ciência "Raimundo Lúlio”, 2005, 462 p.

BETTANINI, Tonino. "Espaço e Ciências Humanas”. Tradução de Liliana Laganá. F. Rio de Janeiro: Ed. Paz e Terra, 1982, 157 p.

BEZERRA, Cícero Cunha. "Compreender Plotino e Proclo”. Petrópolis, Rio de Janeiro: Editora Vozes, 2006, 151 p.

BOSI, Alfredo. "História concisa da Literatura Brasileira”. Editora Cultrix, $3^{\circ}$ edição, São Paulo, 1997, 582 p.

BRANDÃO, Ambrósio Fernandes. "Diálogos das Grandezas do Brasil”. Notas de Rodolfo Garcia e introdução de Jaime Cortesão. Edições Dois Mundos Editora Ltda, Rio de Janeiro, 1943, 317 p.

BRANDÃO, Junito de Souza, "Mitologia Grega". Volume I, $18^{\circ}$ edição, Editora Vozes, Petrópolis, 2004, 405 p.

BURKERT, Walter. "Religião Grega na Época Clássica e Arcaica”. Tradução de M. J. S. Loureiro. Serviço de Educação Fundação Calouste Gulbenkian, Lisboa, 1993, 633 p. 
BURNET, John. "A Aurora da filosofia grega". Tradução Vera Ribeiro. Rio de Janeiro: Contraponto, Ed. Puc Rio 2006, 383 p.

CAMINHA, Pêro Vaz de. "A Carta de Pêro Vaz de Caminha". Comissão executiva das comemorações do V centenário do nascimento de Pedro Álvares Cabral. Oficinas gráficas, Lisboa, 1968, 60 p.

CAMÕES, Luís de. "Os Lusíadas". Por Campos Monteiro. $4^{\circ}$ ed., Porto, Portugal: Editorial Domingos Barreira, 1948. 470 p.

CAMPBELL, “As Máscaras de Deus - mitologia ocidental”. Tradução Carmen Fisher. São Paulo: Palas Athena, 2004, 471 p.

CÂNDIDO, Antonio. "Formação da literatura brasileira - momentos decisivos". $10^{\circ}$ edição revista pelo autor, Rio de Janeiro : Ouro sobre Azul, 2006, 798 p.

CAPEL, Horácio. "Filosofia y ciência em la Geografia contemporânea - Una introducción a la Geografia”. Ed. Barca Nova, Espanha, 509 p.

CARO, Tito Lucrécio. "Da Natureza". Título original: "De Natura Rerum". In: "Os Pensadores". Tradução e notas Agostinho da Silva, estudos introdutórios de G. Ribbeck. Editora Victor Civita, 1973, 329 p.

CARDIM, Fernão. "Tratados da Terra e Gente do Brasil". Introdução de Rodolfo Garcia. Belo Horizonte: Ed. Itatiaia, 1980, v. 13, 206 p.

CARVALHO, Marcos Bernardino de Carvalho. "Uma Geografia do Discurso sobre a Natureza". Dissertação apresentada ao curso de Pós-Graduação em Geografia. FFLCHUSP, São Paulo, 1991, 175 p. 
CASAL, Manuel Aires de. “Corografia brazílica, ou relação histórico-geográfica do Reino do Brasil". Composta e dedicada a sua Majestade Fidelíssima por um presbítero secular do Gram Priorado do Crato. Rio de Janeiro: Impressão Régia, 1817, volume I, 342 p.

CASINI, Paolo. “As Filosofias da Natureza”. Tradução Ana Falcão Bastos e Luis Leitão. Editorial Presença Ltda, Lisboa, 1975, 143 p.

. "Newton e a Consciência europeia". Tradução de Roberto Leal Ferreira. São Paulo: Editora da Universidade Estadual Paulista, 1995, 253 p.

CASSIRER, Ernst. "Indivíduo e cosmos na filosofia do Renascimento". Tradução do alemão João Azenha Jr; tradução do grego e do latim Mario Eduardo Viaro. São Paulo, Martins Fontes, 2001, 309 p.

, Ernst. "Ensaio sobre o Homem - Introdução a uma filosofia da cultura humana”. Tradução Tomás Rosa Bueno. São Paulo: Ed. Martins Fontes, 1994, 391 p.

CASTELlO, José Aderaldo. "A Literatura Brasileira - Origens e Unidade (1500-1960)". $1^{\circ}$ edição e $1^{\circ}$ reimpressão. São Paulo: Editora da Universidade de São Paulo, 2004, 2 v.

. "Manifestações literárias da Era Colonial - 1500-1808/1836/”. Editora Cultrix, São Paulo, 1969, 255 p.

CINTRA, Assis. "Nossa Primeira História”. Editora Proprietária, Companhia Melhoramentos de São Paulo, 1922, 148 p.

COSTA, José Silveira da, "Santo Tomás de Aquino e a filosofia cristã". In "Tomás de Aquino: A razão a serviço da fé”. São Paulo, Editora Moderna, 1993, 128 p.

CRISTÓVÃO, Fernando. "Condicionantes Culturais da Literatura de Viagens: Estudos e Bibliografias”. Coordenação de Fernando Cristóvão Carreira, Manuel J. Ramos, Maria B. 
Araújo, Rui M. Loureiro, Horácio P. de Araújo, José da S. Horta, Sara Augusto, Maria A. Amorim, Ana Maria de Azevedo, João Paulo Aparício e Paula Pelúcia. Edições Cosmos, Centro de Literaturas de Expressão Portuguesa da Universidade de Lisboa, 1999, 15-52 p.

CUNHA, Antonio Geraldo. "Dicionário histórico das palavras portuguesas de origem tupi”. Editora Melhoramentos, São Paulo, 1998, 397 p.

DENIS, Ferdinand. "Brasil”. Prefácio Mário Guimarães Ferri; Belo Horizonte: Ed. Itatiaia; São Paulo: Ed. Da Universidade de São Paulo, 1980. 434 p.

DETIENNE, Marcel y SISSA, Giulia. “Os Deuses Gregos - A vida cotidiana”. Tradução Rosa Maria Boaventura. São Paulo: Companhia das Letras, 1990, 315 p.

DURÃO, José de Santa Rita. "Caramuru: poema épico sobre o descobrimento da Bahia". Introdução, organização e fixação de texto Ronald Polito. $2^{\circ}$ ed. São Paulo, Martins Fontes, 2005, 335 p.

ECO, Humberto. “Como se faz uma tese”. São Paulo: Ed. Perspectiva, 2000. 170 p.

EPICURO - "Antologia de Textos". In Os Pensadores, volume V. Tradução e notas Agostinho da Silva, Estudos introdutórios de E. Joyau e G. Ribbeck. Editor Victor Civita, 1973, 329 p.

ESTRABÃO. “Geografía”. Libros I-II. Introdución de J. García Blanco. Traducción y notas de J. García Ramón y J. García Blanco. Editorial Gredos, Madrid, 1991, 559 p.

FONTANA, Riccardo. "O Brasil de Arnérico Vespúcio”. Brasília: UNB/Linha Gráfica, 1995, 135 p. 
FRANCO, Afonso Arinos de Melo. "O Índio e a Revolução Francesa: As origens brasileiras da teoria da bondade natural". Introdução Alberto Venâncio Filho e Prefácio de Sergio Paulo Rouanet, Topbooks, $3^{\mathrm{a}}$ edição, 318 p.

GAMA, Basílio da. "O Uraguay". In Obras Poéticas de Basílio da Gama: Ensaio e Edição Crítica de Ivan Teixeira. São Paulo: Ed. Universidade de São Paulo, 1996, 474 p.

GANDAVO, Pero de Magalhães. "Tratado da Terra do Brasil ; História da Província de Santa Cruz". Belo Horizonte: Editora Itatiaia; São Paulo: Editora da Universidade de São Paulo, 1980, 150 p.

. "A Primeira História do Brasil - História da Província de Santa Cruz a que vulgarmente chamamos Brasil”. Modernização do texto original de 1576 e notas: Sheila Moura Hue e Ronaldo Menegaz. Rio de Janeiro: Jorge Zahar, 2004, 207 p.

GILSON, Étienne. “O espírito da filosofia medieval”. Tradução Eduardo Brandão. São Paulo: Martins Fontes, 2006, 591 p.

GILSON, Etienne y BOEHNER, Philotheus. "História da Filosofia Cristã - Desde as origens até Nicolau de Cusa". Tradução e nota introdutória de Raimundo Vier, editora Vozes, $11^{\circ}$ edição, Petrópolis, 2008, 582 p.

GIUCCI, Guilhermo. "Viajantes do Maravilhoso - O Novo Mundo". Tradução Josely Vianna Batista. São Paulo: Ed. Companhia das Letras, 1992. 239 p.

. "Sem Fé, Lei ou Rei - Brasil 1500 a 1532". Tradução de Carlos Nougué. Rio de Janeiro: Ed. Rocco, 1993. 239 p.

GOMES, Pinharanda. "Filosofia Grega Pré-Socrática". Lisboa, Guimarães Editores, quarta edição, 1994, 238 p. 
HADOT, Pierre. "O Véu de Isis - Ensaio sobre a história da idéia de natureza”. Tradução Mariana Sérvulo. Edições Loyola, São Paulo, Brasil, 2006, 359 p.

HANSEN, João Adolfo. “A Sátira e o Engenho - Gregório de Matos e a Bahia do século XVI'. São Paulo: Ateliê Editorial; Campinas: Ed. da Unicamp, 2a edição rev., 2004. 523 p.

HERÓDOTO. "História - o relato clássico da guerra entre Gregos e Persas". Tradução de J. Brito Broca, $2^{\circ}$ edição, São Paulo: Ediouro, 2001, 1071 p.

HESÍODO, “Teogonia - a origem dos deuses"; tradução Jaa Torrano, edição revisada do original grego. Editora Iluminuras, $7^{\circ}$ ed. - 2007, São Paulo, 159 p.

. “Os Trabalhos e os Dias". Introdução, tradução e comentários Mary de Camargo Neves Lafer. Editora Iluminuras, 5ºd. - 2006, São Paulo, 101 p.

HOLANDA, Sergio Buarque. "Visão do Paraíso - os motivos edênicos no descobrimento e colonização do Brasil’. 6º edição, São Paulo: Ed. Brasiliense 1996, 375 p.

. "Raízes do Brasil". Prefácio de Antônio Cândido. 11. ed. Rio de Janeiro, J. Olympio, 1977, 154 p.

. "Raízes do Brasil". Prefácio de Antônio Cândido. 26a . ed. São Paulo: Cia das Letras, 1995, $365 \mathrm{p}$.

• "História Geral da Civilização Brasileira". Tomo I - A Época Colonial, do descobrimento à expansão territorial, $1^{\text {o }}$ volume. Difusão Europeia do Livro, São Paulo, 1960, 389 p.

HOMERO. “A Ilíada”. Tradução e adaptação de Fernando C. de Araújo Gomes. Ediouro, Rio de Janeiro, 1991, 275 p. 
KERÉNY, Karl. “Os Deuses Gregos”. Tradução de Octavio Mendes Cajado. Editora Cultrix, $4^{\circ}$ edição, 2004, São Paulo, 219 p.

KOYRÉ, Alexandre. "Do Mundo fechado ao universo infinito”. Tradução de Donaldson M. Garschagen; apresentação e revisão técnica Manoel Barros da Motta. 4.ed. Rio de Janeiro: Editora Forense Universitária, 2006, 287 p.

KRANZ, Walther. "La Filosofia Griega”. Editora Unión Tipográfica Editorial HispanoAmericana, México, 1962, 114 p.

LAN, Conrado Eggers y JULIÁ, Victoria E. “Los Filósofos Presocráticos”. Introducción General por Conrado E. Lan. Introducciones, Traducciones y notas por Conrado E. Lan y Victoria E. Juliá. Editorial Gredos S.A. Madri, 1986, 518 p.

LEIBNIZ, Gottfried Wilhelm, “A 'Protogaea' de G. W. Leibniz (1749): uma teoria sobre a evolução e a origem dos fósseis”. Traduzido por Nelson Papavero, Dante M. Teixeira, Maurício de C. Ramos; São Paulo: Plêiade, FAPESP, 1997, 291 p.

LENOBLE, Robert. "História da Ideia de Natureza". Tradução de Teresa Louro Pérez, edição Albin Michel, 1969, 367 p.

LUCRÉCIO, Tito Lucrécio Caro. "Da Natureza”. Título original: “De Natura Rerum”, in: Os Pensadores. Tradução e notas Agostinho da Silva, estudos introdutórios de G. Ribbeck. Editor Victor Civita, 1973, 329 p.

MAGALHÃES, Couto de. “O Selvagem”. Prefácio Vivaldi Moreira. Belo Horizonte: Ed. Itatiaia; São Paulo: Ed. USP, 1975, 473 p.

MARX, Karl. "Diferenças entre as filosofias da Natureza em Demócrito e Epicuro". Tradução Edson Bini, Armandina Venâncio, Paulo Flor e Anna Prado. Global Editora, São Paulo, s/ data, 128 p. 
MERLEAU-PONTY, Maurice. “A Natureza”. Tradução de Álvaro Cabral. São Paulo: Ed. Martins Fontes, 2000, 448 p.

MILLER, René Fullop. “Os Jesuítas - seus segredos e seu poder”. Tradução Álvaro franco. Edição da livraria Globo, Porto Alegre, 1932, 530 p.

MONTAIGNE, Michel. “Dos Canibais”. In Os Pensadores. Livro Primeiro, Cap. XXXI. v. XI, 104 p.

MOREIRA, Ruy. "Pensar e ser em geografia: ensaios de história, epistemologia e ontologia do espaço geográfico". $1^{\circ}$ ed. $1^{\circ}$ reimpressão. São Paulo: Contexto, 2008, 188 p.

NAVARRO, Eduardo de Almeida. “A Terra Sem Mal, O Paraíso Tupi-Guarani”. In Cultura Vozes, $n^{\circ} 2$, março-abril de 1995.

, "Uma Sinopse da Literatura de Viagem no Brasil dos séculos XVI e XVII". Artigo, Área de Literatura Brasileira - Universidade de São Paulo, 13 p.

NEVES, José Cassiano. “A Expansão Ultramarina e o Reino do Preste João”. In Ocidente Volume LVII, Lisboa, 1959.

NÓBREGA, Manuel da. "Diálogo do Padre Nóbrega sobre a Conversão do Gentil”. Cartas Jesuíticas. Cartas do Brasil. Rio de Janeiro, 1931.

OVÍDIO, “Metamorfoses”. Tradução Manuel Maria du Bocage. Editora Martin Claret, São Paulo, 2003, 135 p.

PARMÊNIDES. "Da Natureza”. Tradução, notas e comentários José Trindade Santos. São Paulo: Edições Loyola, 2002, 119 p.

PEREIRA, Paulo Roberto (Org.). "Os três únicos testemunhos do Descobrimento do Brasil". 2a ed., Rio de Janeiro: Lacerda Editores, 1999, 107 p. 
PEREIRA, Duarte Pacheco. "Esmeraldo de situ orbis". Edição de Raphael Eduardo de Azevedo Basto. Lisboa: Imprensa Nacional, 1897.

PITA, Rocha. "História da América Portuguesa". Apresentação de Mário Guimarães Ferri; introdução e notas de Pedro Calmon, Belo Horizonte: Ed. Itatiaia; São Paulo: Ed. Da Universidade de São Paulo, 1976. 293 p.

PLATÃO. "Fédon”. Tradução Heloísa G. Burati. Editora Rideel, São Paulo, 2005, 128 p.

. "Diálogos - Fédon". In: "Os Pensadores", capítulo 3. Traduções de: Jorge Paleikat e João C. Costa. Ed. Victor Civita, São Paulo, 1972, 269 p.

. "Timeu e Crítias ou A Atlântida". Tradução, Introdução e Notas: Norberto de Paula Lima. Hemus editora limitada, São Paulo, 217 p.

. "Diálogos: Timeu - Crítias - O Segundo Alcebíades - Hípias Menor". Tradução de Carlos Alberto Nunes. 3. ed. Ver. Belém: Edufpa, 2001, 221 p.

PLÍNIO, o velho. "História Natural". Livros I-II, Introdução geral Guy Serbat. Tradução e notas de Antônio Fontán e Ana Moure Casas. Ed. Gredos, S. A., Madrid, 1995, 484 p.

PLOTINO, "Tratados das Enéadas". Tradução, apresentação, introdução e notas de Américo Sommerman. São Paulo: Polar Editorial, 2000, 188 p.

PRÉ-SOCRÁTICOS. In: "Os Pensadores". Seleção de textos e supervisão de José C. de Souza. Capítulo 1. Editora Victor Civita, $1^{\circ}$ edição, São Paulo, 1973, 376 p.

RIBEIRO, Darcy. "O povo brasileiro - A formação e o sentido do Brasil”. São Paulo: Ed. Companhia das Letras, 1995. 476 p. 
SALVADOR, Frei Vicente do. "História do Brasil - 1500-1627". Revisão de Capistrano de Abreu, Rodolfo Garcia e Frei Venâncio Wílleke. Apresentação Aureliano Leite. $7^{0}$ ed., Belo Horizonte. Ed. Itatiaia, São Paulo: Ed. da Universidade de São Paulo, 1982, 427 p.

SANTOS, Milton. "A Natureza do Espaço - Técnica e Tempo, Razão e Emoção". $4^{\circ}$ ed., São Paulo: Ed. Universidade de São Paulo, 2004. 384 p.

SEVERINO, Antônio Joaquim. "Metodologia do Trabalho Científico". Universidade de São Paulo: Ed. Cortez, 10 edição, 1982, 195 p.

SIMPSON, Pablo. "Antologia da poesia árcade brasileira". Organização, notas, prefácio e fixação de texto de Pablo Simpson. São Paulo: Companhia Editora Nacional: Lazuli Editora, 2007, 127 p.

SÓCRATES. In: "Os Pensadores". Capítulo 1. Tradução de Jaime Bruna. Editora Victor Civita, São Paulo, 1972, 230 p.

SOUSA, Gabriel Soares de. "Tratado Descritivo do Brasil em 1587". Estudo e exame de muitos códices manuscritos existentes no Brasil, Portugal, Espanha e França e acrescentada de alguns comentários por Francisco Adolfo de Varnhagen, $5^{\circ}$ edição comemorativa dos quatrocentos anos da obra. São Paulo: Editora Nacional, 1987, 389 p.

TAYLOR, Alfred Edward. "El Platonismo y su influencia”. Traducción por Luís Farré. Editorial Nova, Buenos Aires, 1946, 171 p.

TEIXEIRA, Ivan, "Obras Poéticas de Basílio da Gama: Ensaio e Edição Crítica de Ivan Teixeira”. São Paulo: Editora da Universidade de São Paulo, 1996, 476 p.

TEYXEIRA, Bento e PILOTO, Afonso Luiz. "Naufragio e Prosopopea". Texto conforme a edição de 1601, com introdução, notas e glossário pelo professor Fernando de Oliveira 
Mota. Prefácio de José Antonio Gonsalves de Oliveira Mello. Recife, Universidade Federal de Pernambuco, 1969, 206 p.

VARNHAGEN, Francisco Adolfo. "História Geral do Brasil". Revisão e notas J. Capistrano de Abreu e Rodolfo Garcia. 10 ed. Integral, Belo Horizonte: Ed. Itatiaia; São Paulo: Ed. Da Universidade de São Paulo, 1981, 3 v.

VASCONCELOS, Simão de. "Crônica da Companhia de Jesus". Introdução de Serafim Leite, $3^{\circ}$ edição, volume I, Petrópolis, Editora Vozes Ltda, em convênio com o Instituto do Livro - Ministério da Educação e Cultura, 1977, 2 v., 278 p.

VERNANT, Jean Pierre. "Mito e Religião na Grécia Antiga". Tradução: Joana Angélica D’Ávila Melo. São Paulo: WMF Martins Fontes, 2006, 93 p.

. "O universo, os deuses, os homens". Tradução de Rosa freire d'Aguiar. São Paulo: Companhia das Letras, 2000, 209 p.

VIEIRA, Antonio. "Sermões”. Organização e introdução Alcir Pécora. São Paulo: Editora Hedra, 2003, 2 v.

VIRGÍLIO, "Bucólicas". Tradução, edição anotada e comentada pelo Grupo de Trabalho Odorico Mendes. Editora Unicamp, 2008, 205 p.

, "Geórgicas". Trasladadas ao português por Antonio Feliciano de Castilho. Heros gráfica editora, São Paulo, 1930, 183 p.

VLASTOS, Gregory. “O Universo de Platão”. Tradução de Maria Luiza Monteiro Salles Coroa. Brasília, Editora Universidade de Brasília, 1987, 116 p. 